\section{Pacific Northwest}

National Laboratory

Operated by Battelle for the

U.S. Department of Energy

\title{
Borehole Summary Report for Waste Treatment Plant Seismic Borehole C4996
}
S. C. Adams
B. J. Garcia
S. T. Ahlquist
C. F. Rust
J. R. Fetters

January 2007

Prepared by Freestone Environmental Services, Inc. and Fluor Hanford, Inc.

for the Pacific Northwest National Laboratory

under Contract DE-AC05-76RL01830

with the U.S. Department of Energy 


\title{
DISCLAIMER
}

This report was prepared as an account of work sponsored by an agency of the United States Government. Neither the United States Government nor any agency thereof, nor Battelle Memorial Institute, nor any of their employees, makes any warranty, express or implied, or assumes any legal liability or responsibility for the accuracy, completeness, or usefulness of any information, apparatus, product, or process disclosed, or represents that its use would not infringe privately owned rights. Reference herein to any specific commercial product, process, or service by trade name, trademark, manufacturer, or otherwise does not necessarily constitute or imply its endorsement, recommendation, or favoring by the United States Government or any agency thereof, or Battelle Memorial Institute. The views and opinions of authors expressed herein do not necessarily state or reflect those of the United States Government or any agency thereof.

\author{
PACIFIC NORTHWEST NATIONAL LABORATORY \\ operated by \\ BATTELLE \\ for the \\ UNITED STATES DEPARTMENT OF ENERGY \\ under Contract DE-AC05-76RL01830
}

Printed in the United States of America
Available to DOE and DOE contractors from the
Office of Scientific and Technical Information,
P.O. Box 62, Oak Ridge, TN 37831-0062;
ph: (865) 576-8401
fax: (865) 576-5728
email: reports@adonis.osti.gov

\author{
Available to the public from the National Technical Information Service, \\ U.S. Department of Commerce, 5285 Port Royal Rd., Springfield, VA 22161 \\ ph: (800) 553-6847 \\ fax: (703) 605-6900 \\ email: orders@ntis.fedworld.gov \\ online ordering: http://www.ntis.gov/ordering.htm
}

This document was printed on recycled paper. 


\section{Borehole Summary Report for Waste Treatment Plant Seismic Borehole C4996}

Prepared for the U.S. Department of Energy

Assistant Secretary for Environmental Management

Project Hanford Management Contractor for the

U.S. Department of Energy under Contract DE-AC06-96RL13200

FLUOR。

P.O. Box 1000

Richland, Washington 
WMP-32076

Revision 0

\section{Borehole Summary Report for Waste Treatment Plant Seismic Borehole C4996}

Document Type: RPT

Program/Project: WM

S. C. Adams

S. T. Ahlquist

J. R. Fetters

B. J. Garcia

C. F. Rust

Freestone Environmental Services, Inc.

Date Published

January 2007

Prepared for the U.S. Department of Energy

Assistant Secretary for Environmental Management

Project Hanford Management Contractor for the

U.S. Department of Energy under Contract DE-AC06-96RL13200

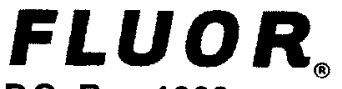

P.O. Box 1000

Richland, Washington

Release Approval Eazolal $\frac{01 / 39 / 2007}{\text { Date }}$

Approved for Public Release:

Further Dissemmation Unlimited 
WMP-32076

Revision 0

TRADEMARK DISCLAIMER

Reference herein to any specific commercial product, process,

or service by trade name, trademark, manufacturer, or

otherwise, does not necessarily constitute or imply its

endorsement, recommendation, or favoring by the United

States Government or any agency thereof or its contractors or subcontractors.

This report has been reproduced from the best available copy.

Printed in the United States of America 
WMP-32076, Rev. 0

APPROVAL PAGE

Title:

Approvals:
Borehole Summary Report for Waste Treatment Plant Seismic Borehole C4996

L. C. Swanson

Manager, Geosciences, Groundwater Remediation Project

ZCXularom

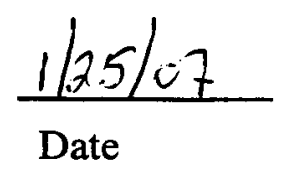

Signature

Date

J. A. Winterhalder

Environmental Compliance Officer, Groundwater Remediation Project

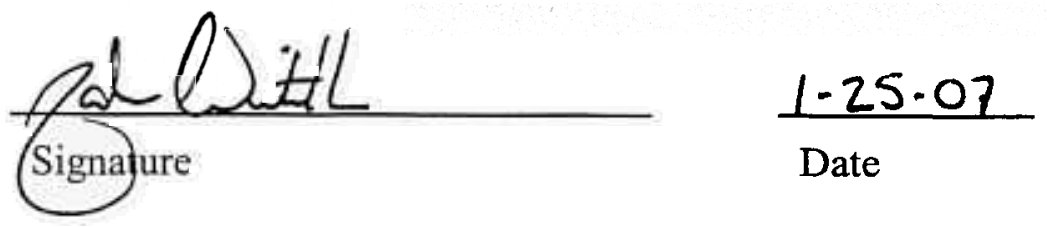

C. S. Wright

Task Lead, Groundwater Remediation Project

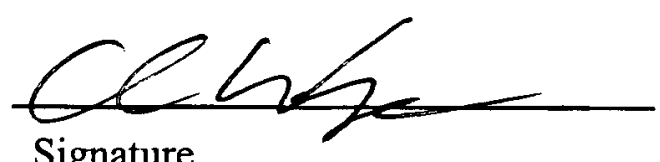

Signature

$1 / 25 / 07$

Date 
WMP-32076 Rev. 0

This page intentionally left blank 


\section{TABLE OF CONTENTS}

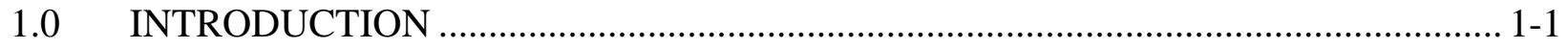

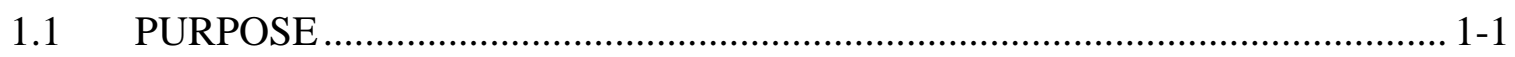

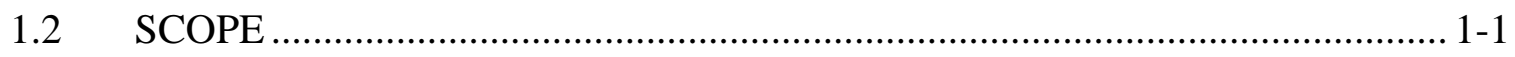

2.0 BACKGROUND ............................................................................................ 2-1

2.1 QUALITY ASSURANCE AND QUALITY CONTROL

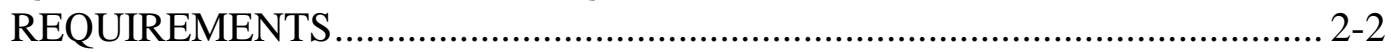

3.0 GEOLOGICAL SAMPLING …………............................................................. 3-1

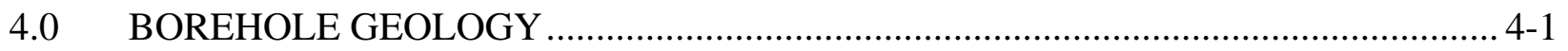

4.1 BASALT UNITS ……………....................................................... 4-1

4.1.1 Elephant Mountain Member of the Saddle Mountains Basalt ................... 4-1

4.1.2 Pomona Member of the Saddle Mountains Basalt....................................... 4-1

4.1.3 Esquatzel Member of the Saddle Mountains Basalt .................................. 4-2

4.1.4 Umatilla member of the Saddle Mountains Basalt .................................... 4-2

4.1.5 Priest Rapids Member of the Wanapum Basalt ......................................... 4-3

4.1.6 Roza Member of the Wanapum Basalt ....................................................... 4-3

4.2 SEDIMENTARY UNITS ................................................................ 4-4

4.2.1 Ellensburg Formation, including the Rattlesnake Ridge, Selah, Cold Creek, Mabton, and Byron Interbeds ................................................ 4-4

4.3 NOTES ON GEOLOGY AND SAMPLING TECHNIQUES ............................. 4-5

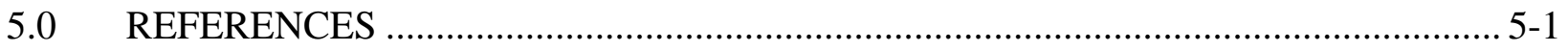

\section{APPENDICES}

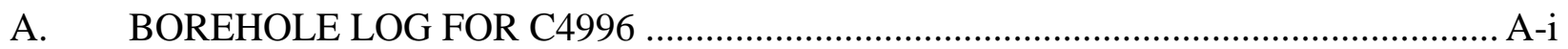

B. BOREHOLE C4996 SAMPLE INVENTORY ……………………………............ B-i

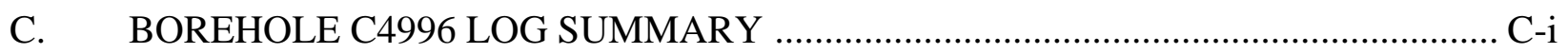

D. FREESTONE ENVIRONMENTAL SERVICES, INC. PROJECT DESK

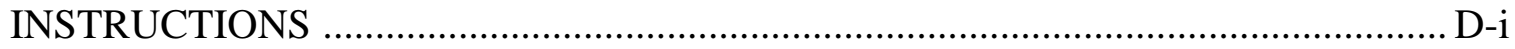

E. PHOTOGRAPHIC LOG OF BOREHOLE CUTTINGS …………………...................... 
WMP-32076 Rev. 0

\section{FIGURES}

Figure 1. Location of WTP Seismic Boreholes (Gardner et al. 2006)........................................1-2

\section{TABLES}

Table 1 C4996 Summary of Sedimentary Interbeds................................................................ 4-4 
WMP-32076 Rev. 0

\section{ACRONYMS}

bgs

below ground surface

$\mathrm{FH}$ Fluor Hanford, Inc.

Freestone Freestone Environmental Services, Inc.

ICN Interim Change Notice

PNNL

SAP Pacific Northwest National Laboratory

WTP sampling and analysis plan

Waste Treatment Plant 
WMP-32076 Rev. 0

This page intentionally left blank 
WMP-32076 Rev. 0

\subsection{INTRODUCTION}

This report presents the field-generated borehole log, lithologic summary, and the record of samples collected during the recent drilling and sampling of the basalt interval of borehole C4996 at the Waste Treatment Plant (WTP) on the Hanford Site. Borehole C4996 was one of four exploratory borings, one core hole and three boreholes, drilled to investigate and acquire detailed stratigraphic and down-hole seismic data. This data will be used to define potential seismic impacts and refine design specifications for the Hanford Site WTP. All completed well locations are shown in Figure 1.

Requirement documents controlling the borehole drilling and geologic logging include the Sampling and Analysis Plan Waste Treatment Plant Seismic Boreholes Project (herein referred to as the WTP SAP) (PNNL-15848) and the Fluor Hanford, Inc (FH) Groundwater Remediation Project Procedure “Geologic Logging” (GRP-EE-01-7.0).

All data in this report are presented in the English units in which they were measured.

\subsection{PURPOSE}

The purpose of this document is to compile field records and summarize observations and measurements made by the wellsite geologist during the drilling, the visual characterization of the cuttings, and sample collection process during the drilling of borehole C4996. This information was recorded at the wellsite on the borehole log form (FH form A-6003-642). The borehole log for C4996 is presented in Appendix A.

\subsection{SCOPE}

Freestone Environmental Services, Inc. (Freestone) was subcontracted to Fluor Hanford (FH) to support geologic logging during the drilling of the basalt interval of borehole C4996. The scope of work for the C4996 wellsite geology support activity was to collect, examine, describe, and containerize rock chips from 5-ft depth intervals or recognized changes in lithology during the drilling of borehole C4996. The wellsite support contract solely addressed the drilling of the basalt and sedimentary interbed stratigraphy of borehole C4996 and excluded support work during the drilling of the upper unconsolidated sediment interval ( 0 to $390 \mathrm{ft}$ below ground surface [bgs]) of C4996. Entry hole geologic logging and cuttings sampling was performed by another project subcontractor. Significant data were collected by other project sub-contractors in the form of drill performance data, health and safety monitoring records, and borehole geophysical logs. This information will be released in separate project documents.

The overall objectives, applicable procedures and standards, and organizational responsibilities are stated in Revision 0 of the WTP SAP (PNNL-15848a) and subsequent revisions. The borehole through the unconsolidated zone and part way into the basalt was completed using Revision 1a of the WTP SAP (PNNL-15848b) and Interim Change Notice (ICN) 15848-1.1. Continued drilling of C4996 used the requirements from Revision 2 of the WTP SAP (PNNL-15848c) and ICNs 15848-2.1 and 15848-2.2. Subsequent direction from Pacific Northwest National Laboratory (PNNL) increased the total depth of C4996 to drill through an additional underlying basalt flow and interbed. 
WMP-32076 Rev. 0

Figure 1. Location of WTP Seismic Boreholes (Gardner et al. 2006).

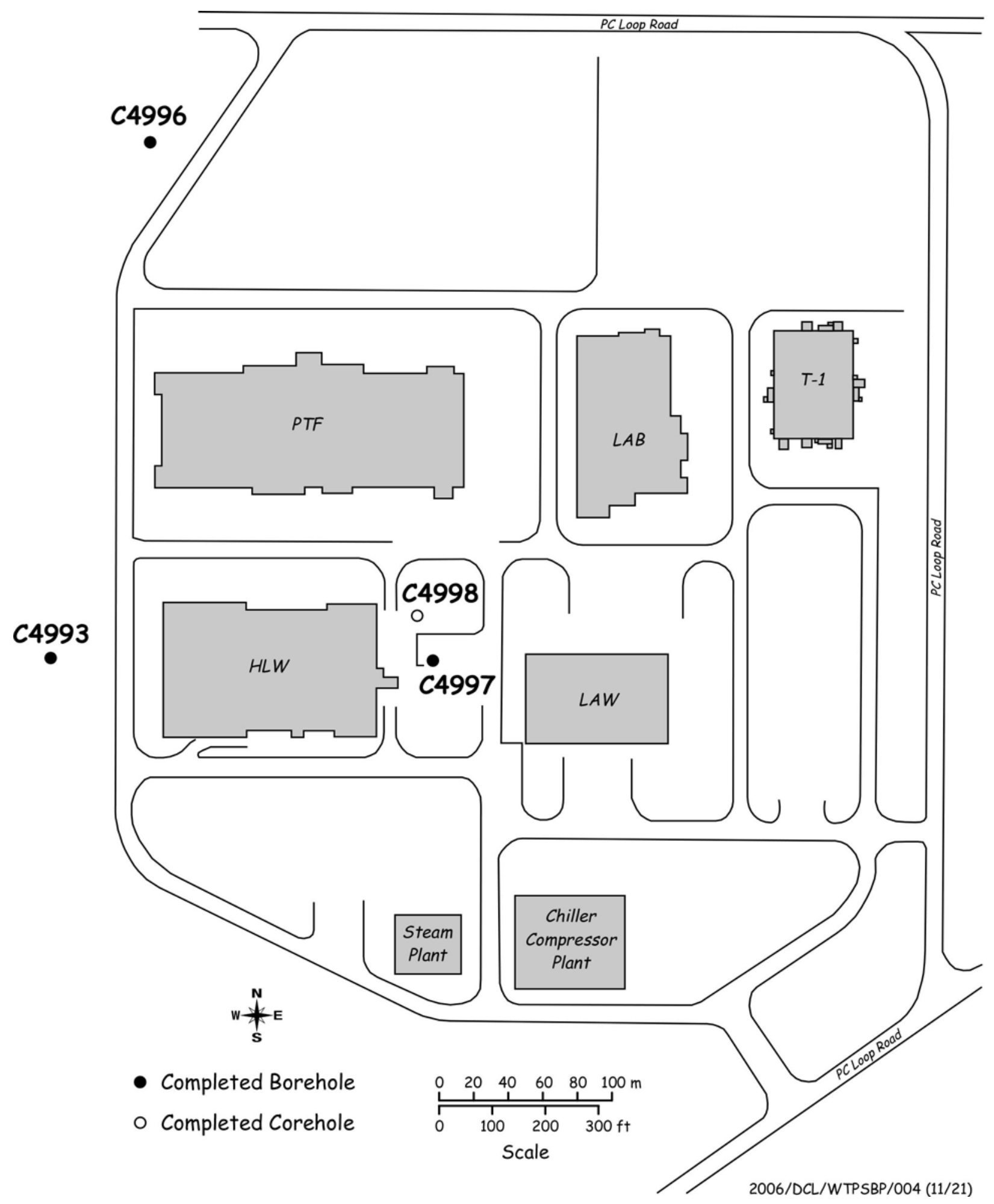


WMP-32076 Rev. 0

\subsection{BACKGROUND}

The seismic design basis for the WTP at the Department of Energy's (DOE) Hanford Site near Richland, Washington was re-evaluated in 2005 , resulting in an increase by up to $40 \%$ in the seismic design basis. The original seismic design basis for the WTP was established in 1999 based on a probabilistic seismic hazard analysis completed in 1996. The 2005 analysis was performed to address questions raised by the Defense Nuclear Facilities Safety Board (DNFSB) about the assumptions used in developing the original seismic criteria and adequacy of the site geotechnical surveys. The updated seismic response analysis used existing and newly acquired seismic velocity data, statistical analysis, expert elicitation, and ground motion simulation to develop interim design ground motion response spectra which enveloped the remaining uncertainties. The uncertainties in these response spectra were enveloped at approximately the $84^{\text {th }}$ percentile to produce conservative design spectra, which contributed significantly to the increase in the seismic design basis.

A key uncertainty identified in the 2005 analysis was the velocity contrasts between the basalt flows and sedimentary interbeds below the WTP. The velocity structure of the upper four basalt flows (Saddle Mountains Basalt) and the interlayered sedimentary interbeds (Ellensburg Formation), produces strong reductions in modeled earthquake ground motions propagating through them. Uncertainty in the strength of velocity contrasts between these basalts and interbeds primarily resulted from an absence of measured shear wave velocities (Vs) in the interbeds. For this study, Vs in the interbeds was estimated from older, limited compressional wave $(\mathrm{Vp})$ data using estimated ranges for the ratio of the two velocities $(\mathrm{Vp} / \mathrm{Vs})$ based on analogues in similar materials. A range of possible Vs for the interbeds and basalts was used and produced additional uncertainty in the resulting response spectra.

Because of the sensitivity of the calculated response spectra to the velocity contrasts between the basalts and interbedded sediments, DOE initiated the seismic boreholes project (SBP) to emplace additional boreholes at the WTP site and obtain direct Vs measurements and other physical property measurements in these layers. One corehole and three boreholes were installed at the WTP site to a maximum depth of 1500 feet below ground surface (Figure 1). The three boreholes are within 500 feet of and surrounding the high level waste vitrification and pretreatment facilities of the WTP, which were the Performance Category 3 (PC3) structures affected by the interim design spectra. The corehole is co-located with the borehole closest to the two PC-3 structures. These new measurements are expected to reduce the uncertainty in the modeled site response that is caused by the lack of direct knowledge of the Vs contrasts within these layers.

The entry hole intervals for all seismic boreholes were drilled with a cable tool drill rig and cased through the unconsolidated gravels, sands and silts down to the top of the basalt. The initial borehole, C4998, was drilled with a core rig to provide physical samples for detailed characterization and testing of the basalt and sedimentary interbeds. The remaining three boreholes in the program, including C4996, were drilled by rotary drill equipment and tri-cone 
bits which produced rock chips and finer material as the drill cuttings. Bentonite mud was used as the drilling fluid to support the hole and return drill chips to the surface.

The borehole diameter of C4996 was 7.625-in. diameter button-type tri-cone rock bit. The borehole was drilled over the period July 31 to September 6, 2006 and reached a total depth of $1467.8 \mathrm{ft}$ bgs.

\subsection{QUALITY ASSURANCE AND QUALITY CONTROL REQUIREMENTS}

The WTP SAP (PNNL-15848) established organizational responsibilities, actions to be completed, and specified that geology aspects were to be recorded using GRP-EE-01-7.0. In response to these requirements, Freestone prepared a desk instruction (Freestone 2006, Desk Instruction for Records Management to Support Waste Treatment Plant - PNNL Seismic Boreholes Project) to ensure the integrity of sample and records. These desk instructions are provided in Appendix D of this document.

The Freestone instruction emphasized the importance of maintaining accurate measurements and concise and consistent record keeping. It also emphasized training, control of records, quality control, inspection and approval of records, change control of records, and physical control of a duplicate records, as well as physical transfer of custody of samples and records. The desk instruction identified samples as physical records. Freestone utilized an independent quality control process to assure accuracy, consistency, and legibility of records. 
WMP-32076 Rev. 0

\subsection{GEOLOGICAL SAMPLING}

For the Freestone scope of work, rotary drill cuttings of basalt were the most frequently collected samples and made up the bulk of the materials archived. Within the WTP SAP (PNNL-15848), PNNL provided a reference stratigraphic description with anticipated depths and projected unit thicknesses at Borehole C4996. In addition, geologic information was available from the concurrent drilling of the nearby C4998 corehole. PNNL also supplied reference photographs of core from two older core holes. All available sources were utilized to anticipate unit contacts and facies changes.

The WTP SAP required collection of drill cuttings from 5-ft depth intervals or when changes in lithology were recognized to the total depth of the borehole. A continuous effort was made to monitor the borehole depth since the rig-mounted geolograph did not always provide an accurate record of drill depth. A borehole depth tally was provided by the driller to identify the borehole depth.

The basalt cuttings were generally collected from the shale shaker located alongside the rotary drill rig. The collection process involved scraping a shovel full of cuttings from the discharge slide end of the vibrating shaker table, which screened the cutting from the bentonite drilling fluid. Most samples were then washed with water while held in a hand screen to remove the drilling mud and particles of mud additives. As orally directed by the PNNL Project Geologist, cuttings from some intervals were not washed.

When drilling through the sedimentary interbeds, most zones did not return cuttings of a size that collected on the shaker table discharge slide. In this case, some cuttings could be directly collected with the hand-screen from the discharge side of the surface casing. Additional cuttings in the form of a thickened slurry could be collected in a jar directly from the sand cyclones on the shale shaker. It was noted in the borehole log that the bottled slurry samples might not be representative of the interbed lithology interval, because of intermixing caused by intermittent operation of the sand pump in the shale shaker (see Section 4.3 "Notes on Geology and Sampling Techniques”).

The individual grab sample was divided and portions were stored in a labeled one-pint volume glass jars, a cloth sample-collection bag and in a plastic cuttings tray. A representative portion was inspected by eye, 10 power hand lens, 50 power pocket microscope, and/or variable-power binocular microscope and the depth range and geologic description was recorded on the borehole log form. The description was made based upon the rock type, color, fracture pattern, mineralogy, crystals found, and other features that could be visibly distinguished. Borehole log sheets were duplicated and filed as in-progress-working records as soon as they were completed in draft.

Borehole logging was coordinated with the drilling progress to note drilling characteristics, such as drilling speed and torque or vibration of the drill stem as may be experienced in fracture zones. Communication with the driller was maintained to identify when depth errors were introduced to the geolograph. Bottles, chip trays, and air dried sample bags were moved inside of the support trailer as soon as the container was filled.

The borehole log for C4996 is located in Appendix A. The inventory of samples collected during drilling is provided in Appendix B. Appendix C, "Borehole C4996 Log Summary," summarizes the observations recorded in the borehole log sheets. A photographic log of the drill 
WMP-32076 Rev. 0

cuttings that were collected in the chip trays was prepared by PNNL and is included as Appendix E. 
WMP-32076 Rev. 0

\subsection{BOREHOLE GEOLOGY}

The geology of the Hanford Site and the deep subsurface has been investigated in previous studies, most importantly during the Basalt Waste Isolation Project (BWIP) and is presented in detail in Geologic Studies of the Columbia Plateau-A Status Report (RHO-BWI-ST-4), and Volume 2 of the Site Characterization Plan (DOE/RW-0164) along with other documents.

Following is the background geologic description, as well as a summary of the observed geology of the units encountered during the drilling of borehole C4996. The overall sequence drilled can be generally summarized as basalt flows alternating with sedimentary units.

\subsection{BASALT UNITS}

\subsubsection{Elephant Mountain Member of the Saddle Mountains Basalt}

The Elephant Mountain Member is the uppermost Columbia River Basalts unit present in the study area and is separated from the underlying Pomona Member by the Rattlesnake Ridge interbed of the Ellensburg Formation. Beneath the Hanford Site, this single flow has an average thickness of $100 \mathrm{ft}$ with a range of $15 \mathrm{ft}$. In borehole C4996, the Elephant Mountain basalt has a total thickness of $101 \mathrm{ft}$ and was encountered between $349 \mathrm{ft}$ and $450 \mathrm{ft}$ bgs. This member was medium- to fine-grained with abundant microphenocrysts of plagioclase. Clay, zeolites, calcite, pyrite, and silica are present as fracture and joint fillings, though their exact distribution depends on distribution and dimension of fractures and joints within the basalt flow, as well as the physiochemical properties of the minerals themselves (see Section 4.3 "Notes on Geology and Sampling Techniques”). Calcite and pyrite were noted in the chip samples; though the most common secondary mineral was a green clay.

Evidence for internal features such as plagioclase microphenocrysts, vesicles, and filled fractures/cavities were observed in chip samples, though not uniformly throughout the entire flow (Appendix A). One possible reason for this observed characteristic may be related to the destructive nature of mud rotary drilling, the speed of the bit, and the depth from which the chip sample material was transported (Section 4.3 "Notes on Geology and Sampling Techniques”). The flow top was highly vesicular, amygdaloidal, and oxidized to a reddish-brown color at the contact with the overlying Ringold Formation sediments. The flow bottom was also oxidized, though vesiculation and secondary minerals were much less apparent.

\subsubsection{Pomona Member of the Saddle Mountains Basalt}

The Pomona Member basalt overlies the Esquatzel Member basalt and was separated from it by the Selah interbed of the Ellensburg Formation. In the Hanford Area, this single flow had an average thickness of $185 \mathrm{ft}$ with a range of $10 \mathrm{ft}$. In borehole C4996, the Pomona member was $200.5 \mathrm{ft}$ thick and was encountered between $495 \mathrm{ft}$ and $699.5 \mathrm{ft}$ bgs. This member was logged as fine-grained, glassy, and containing plagioclase (and rarely olivine) phenocrysts. Clay, zeolites and silica were found as fracture and joint fillings in the literature, however, only clay and silica (chalcedony, opal) were observed in the chip samples. A blue-green clay was most often present. 
Evidence for internal features such as plagioclase phenocrysts, vesicles, and filled fractures/cavities were observed in chip samples, though not distributed uniformly throughout the entire flow (see Section 4.1.1). The flow top of the Pomona Member was extremely brecciated and scoriaceous, with a large amount of palagonite present. Palagonite is a tan or brown colloidal material that is a result of the hydration of basaltic glass and shows that this lava flow probably encountered surface water while still in a molten state. The flow bottom was determined based on the disappearance of basalt from the chip samples.

\subsubsection{Esquatzel Member of the Saddle Mountains Basalt}

The Esquatzel Member lies above the Umatilla Member and is separated from it by the Cold Creek Interbed of the Ellensburg Formation. Locally, this single flow has an average thickness of $100 \mathrm{ft}$ with a range of $10 \mathrm{ft}$. In borehole C4996, the Esquatzel Member had a total thickness of $94.5 \mathrm{ft}$ and was encountered between $720 \mathrm{ft}$ and $814.5 \mathrm{ft}$ bgs. This member was fine-grained and plagioclase-phyric, often containing plagioclase glomerocrysts and clinopyroxene microphenocrysts. In chip samples, only fragments of plagioclase phenocrysts were observed. Clay, zeolites and silica were found as fracture and joint fillings in the literature, however, only clay and pyrite were observed in the chip samples.

Evidence for internal features such as plagioclase phenocrysts, vesicles, and filled fractures/cavities were observed in chip samples, though not uniformly throughout the entire flow (see Section 4.1.1). The flow top of the Esquatzel Member is highly weathered to green clay. The presence of fracturing and vesiculation was not readily apparent from the chip samples; however, the driller reported an increase in penetration rate during the first approximately $10 \mathrm{ft}$ of the basalt. Changes in drilling behavior and clay-rich samples from the flow bottom indicate that a moderately-fractured interval overlies a baked contact of basalt and/or sediment. Poor sample returns over this interval, however, render this interpretation tenuous at best.

\subsubsection{Umatilla member of the Saddle Mountains Basalt}

The Umatilla Member is the lowermost and oldest member of the Saddle Mountains Basalt and consists of two flows in the study area, the Umatilla and the Sillusi. The requirements of this particular study did not call for a distinction between these two flows, so this basalt interval was referred to as the Umatilla Member. In the Hanford Area vicinity, this member has an average thickness of $150 \mathrm{ft}$ with a range of $10 \mathrm{ft}$. In borehole C4996, the Umatilla basalt had a total thickness of $156 \mathrm{ft}$ and was encountered between $910.8 \mathrm{ft}$ and $1066.8 \mathrm{ft}$ bgs. This unit is finegrained, plagioclase-phyric, and often extremely glassy, with $\leq 80 \%$ glass in some previouslyanalyzed samples. Plagioclase glomerocrysts and olivine microphenocrysts may also be present, though rare. Clay, zeolites and silica are found as fracture and joint fillings in the literature, however, only clay and pyrite were observed in the chip samples, blue-green clay being the most common.

Evidence for internal features such as plagioclase phenocrysts, vesicles, and filled fractures/cavities were observed in chip samples, though not uniformly throughout the entire flow (see Section 4.1.1). The flow top began abruptly with the appearance of basalt and a variety 
of secondary clay-like minerals in the drill cuttings. Moderate vesiculation and a relatively high (10 to 15\%) proportion of clay minerals persist approximately $50 \mathrm{ft}$ into the flow. The flow bottom was preceded by a slight increase in penetration rate approximately $10 \mathrm{ft}$ from the contact, though without any appreciable increase in the proportion of secondary minerals.

In the interval between $970 \mathrm{ft}$ and $1000 \mathrm{ft}$ bgs, geophysical data suggests the presence of a thin, discontinuous layer of sediment. This 30-ft interval displays lower density and higher conductivity readings than the surrounding basalt. Chip samples from this interval are inconclusive due to the nature of mud-rotary drilling and the sampling process (see section 4.3 Notes on Geology and Sampling Techniques), however, core samples in the same interval from the C4998 Core Hole show variably-fractured zones.

\subsubsection{Priest Rapids Member of the Wanapum Basalt}

The Priest Rapids Member is the uppermost member of the Wanapum Basalt and consists of two flows, the Lolo and the Rosalia flows. Locally, this member had an average thickness of $232 \mathrm{ft}$ with a range of $40 \mathrm{ft}$. In borehole C4996, the Lolo flow had a total thickness of $154 \mathrm{ft}$ and was encountered between $1168 \mathrm{ft}$ and $1322 \mathrm{ft}$ bgs. The Rosalia flow had a total thickness of $70 \mathrm{ft}$ and was encountered between $1325 \mathrm{ft}$ and $1395 \mathrm{ft}$. Separating the two flow units was the approximately $5 \mathrm{ft}$ thick Byron interbed. In general, the Priest Rapids Member basalt described as fine- to medium-grained, glassy and with a high content of plagioclase microphenocrysts. Less common are phenocrysts and glomerocrysts of plagioclase. Micropegmatites, coarse cmscale intergrowths of plagioclase and glass, as well as enclaves of quartz and pyroxene intergrowths, have been observed in this member from other localities. In borehole C4996, very few phenocrysts (plagioclase) and no micropegmatitic zones were found. Silica (opal, chalcedony, quartz), pyrite and clay have been observed in chip samples, presumably as fracture/joint/vesicle-filling material.

Evidence for internal features such as plagioclase phenocrysts, vesicles, and filled fractures/cavities were observed in chip samples, though not uniformly distributed throughout the entire flow (see Section 4.1.1). The flow top designation is based on the disappearance of sediment from the shale shaker and slurry cone output (see Section 3.0 "Geologic Sampling”). The Lolo flow bottom was based on the appearance of a high proportion of sediment. The Rosalia flow top began where basalt again became dominant in the samples.

\subsubsection{Roza Member of the Wanapum Basalt}

In the study area, the Roza Member had an average thickness of $172 \mathrm{ft}$ and was encountered at $1395 \mathrm{ft}$ bgs until total depth for the borehole was achieved at $1467.8 \mathrm{ft}$ bgs. In the literature, this member is characterized by large plagioclase phenocrysts, though samples appear relatively nonporphyritic. The proportion of plagioclase phenocrysts observed in borehole chip samples was variable.

The tentative depth of the Roza flow top is based on changes in drill penetration rate, the presence of oxidized basalt fragments, and a slight increase observed in the amount of plagioclase phenocrysts. 
WMP-32076 Rev. 0

\subsection{SEDIMENTARY UNITS}

\subsubsection{Ellensburg Formation, including the Rattlesnake Ridge, Selah, Cold Creek, Mabton, and Byron Interbeds}

The Ellensburg Formation includes epiclastic and volcaniclastic sedimentary rocks that are interbedded with the Columbia River Basalt Group in the central and western part of the Columbia Plateau. The interbeds encountered during the drilling (and in the greater Ellensburg Formation) were defined based on the upper- and lower-bounding basalt flows. The Rattlesnake Ridge, Selah and Cold Creek interbeds lie within the Saddle Mountains Basalt; the Mabton interbed lies between the Saddle Mountains Basalt and Wanapum Basalt; and the Byron interbed lies between the Lolo and Rosalia flows of the Priest Rapids Member.

Within the study area, the Ellensburg Formation was comprised of quartzitic to arkosic, micaceous sandstone and mudstone with minor conglomerate intervals containing abundant metamorphic and plutonic clasts. Paleosols composed of fine-grained, massive silt and clay were common. The provenance of these sediments is believed to be associated with the ancestral Columbia and Snake Rivers. Layers of airfall tuff often lie within Paleosols, indicating possible Cascade volcanism was active during Columbia River basaltic volcanism. Table 1 provides a summary of recognized interbed characteristics.

During the drilling operation, it was difficult to keep the borehole open in several zones of unconsolidated flowing sands or squeezing clays within the interbeds. It became standard practice for the drilling contractor to backfill the borehole with cement grout through the entire interbed interval to stabilize the formation and then redrill the hole.

Table 1 C4996 Summary of Sedimentary Interbeds

\begin{tabular}{|c|c|c|c|c|c|}
\hline Unit name & $\begin{array}{c}\text { Rattlesnake } \\
\text { Ridge Interbed }\end{array}$ & Selah Interbed & $\begin{array}{l}\text { Cold Creek } \\
\text { Interbed }\end{array}$ & Mabton Interbed & $\begin{array}{c}\text { Byron } \\
\text { Interbed }\end{array}$ \\
\hline $\begin{array}{l}\text { Depth } \\
\text { interval in } \\
\text { feet } \\
\text { (meters) }\end{array}$ & $\begin{array}{c}450-495 \\
(137.3-151.0)\end{array}$ & $\begin{array}{c}699.5-720 \\
(213.3-219.6)\end{array}$ & $\begin{array}{c}814.5-910.8 \\
(248.4-277.8)\end{array}$ & $\begin{array}{c}1066.8-1168 \\
(325.4-356.2)\end{array}$ & $\begin{array}{c}1322-1327 \\
(403.2-404.7)\end{array}$ \\
\hline $\begin{array}{l}\text { Thickness } \\
\text { in feet } \\
\text { (meters) }\end{array}$ & 45 (13.7) & $20.5(6.3)$ & $96.3(29.4)$ & 101.2 (30.9) & $\begin{array}{c}5+/-2 \\
(1.5+/-0.6)\end{array}$ \\
\hline Lithology & $\begin{array}{l}\text { Reddish-brown / } \\
\text { grey-brown / } \\
\text { orange-brown / } \\
\text { brown / pink / } \\
\text { grey / mud, } \\
\text { reddish-brown / } \\
\text { brown, fine- } \\
\text { grained sand, } \\
\text { reddish-brown } \\
\text { rock fragments } \\
\text { (near top) }\end{array}$ & $\begin{array}{l}\text { Brown / green- } \\
\text { grey / grey / } \\
\text { green mud, } \\
\text { very little sand, } \\
\text { brown / tan rock } \\
\text { fragments (near } \\
\text { bottom) }\end{array}$ & $\begin{array}{l}\text { Greenish-grey / } \\
\text { dark bluish-grey } \\
\text { mud, } \\
\text { Olive green / dark } \\
\text { green, very fine- } \\
\text { to coarse sand } \\
\text { (micaceous) }\end{array}$ & $\begin{array}{l}\text { Green / orange / dark } \\
\text { greenish-grey mud, } \\
\text { Dark greenish-grey } \\
\text { fine- to medium } \\
\text { grained sand } \\
\text { (micaceous), } \\
\text { brown rock fragments }\end{array}$ & $\begin{array}{l}\text { Greenish-blue } \\
\text { mud, brown } \\
\text { (mud?) rock } \\
\text { fragments, } \\
\text { mica at lower } \\
\text { contact }\end{array}$ \\
\hline
\end{tabular}


WMP-32076 Rev. 0

\begin{tabular}{|l|l|l|l|l|l|}
\hline Comments & $\begin{array}{l}\text { Highly variable } \\
\text { sequence of } \\
\text { alternating mud } \\
\text { and sand }\end{array}$ & $\begin{array}{l}\text { Mud-rich } \\
\text { interval, color } \\
\text { progresses from } \\
\text { brown to grey to } \\
\text { green from top } \\
\text { to bottom of } \\
\text { sequence }\end{array}$ & $\begin{array}{l}\text { Mud-rich interval } \\
\text { at top and bottom, } \\
\text { large interval of } \\
\text { poorly-sorted, } \\
\text { micaceous sand in } \\
\text { the middle }\end{array}$ & $\begin{array}{l}\text { The upper half of the } \\
\text { interval is alternating } \\
\text { muddy and mud-poor } \\
\text { sands, lower half of } \\
\text { interval is essentially } \\
\text { muddy, poorly-sorted, } \\
\text { micaceous sand }\end{array}$ & $\begin{array}{l}\text { Mud-rich } \\
\text { interval }\end{array}$ \\
& & & & \\
\hline
\end{tabular}

\subsection{NOTES ON GEOLOGY AND SAMPLING TECHNIQUES}

The gravels, sands, and silts of the overlying unconsolidated Hanford and Ringold units were drilled in a cable drilling scope of work, prior to drilling the basalt units and sedimentary interbeds by mud-rotary drill rig. An erosional surface marked the contact between the overlying sediments and the topmost basalt unit at a depth of $349 \mathrm{ft}$. Cable drilling stopped at $364.5 \mathrm{ft}$ bgs, and the entry casing was grouted in place with the top of the cement grout set at $343.5 \mathrm{ft}$ bgs in the borehole.

For all drilled basalt units, several generalities were readily observable.

- Internal basalt structures and fractures were poorly represented in drill cuttings. This was probably due to the destructive nature of mud rotary drilling and the erosion of the chip surfaces as the cuttings material was transported to the surface. At a depth of 941 to $945 \mathrm{ft}$ bgs, the drill bits were changed and the original hemispherical-profile button bit was replaced with a more sharply pointed button bit. Chip size was substantially reduced downward from this depth and many surficial basalt features were probably obliterated. Fracturing or jointing of any kind may be inferred for some intervals by the presence of varying amounts of secondary minerals showing a preferred plane of orientation, i.e., flattening. The difference between cooling joints and natural fracturing, however, cannot be distinguished. The C4996 borehole log included drillers' notifications of fracture zones, which were identified by observable drill responses, and drilling penetration rates.

- Identifying secondary minerals in drill cuttings was extremely difficult because the minerals share many of the same physical properties, and small grain size prohibits most simple, deterministic tests. These two factors may also contribute to the amount of that mineral observed in each sample. For example, a brittle clay particle has a greater chance of disintegrating on the way up and out of the borehole than a more plastic clay. More of the plastic clay would be present in a random sample, but would not correctly reflect the lithology at depth. The absolute amount of secondary minerals present in each chip sample, therefore, may be interpreted only on a very general scale.

Following are a general zoning pattern recognized within the basalt intervals:

- Upper basalt zones generally were fast drilling (3 to $7 \mathrm{ft} / \mathrm{hr}$ ) and fractured with clay fillings in apparent fracture fillings.

- Center zones were slow drilling (1.5 to $3 \mathrm{ft} / \mathrm{hr}$ ) with fewer fractures and much less clay. 
- Very basal zones were alternately hard and slow drilling in the unit. Drilling rates increased to 3 to $9 \mathrm{ft} / \mathrm{hr}$ and gave good warnings when entering clay units at the top of the interbeds.

For the interbeds, cutting returns were very poor. Generally speaking, the only valuable data retrieved was for returns of clay to clay-siltstone sized materials. At times the only retrievable clay-siltstone samples were taken from the surface casing. Many of the clay-siltstone samples were disaggregated before discharged to the shale shaker. Sample returns for sand intervals were very poor. Some grab samples were directly collected from the sand pump discharges and these jar and chip tray samples of sand should be considered suspect and unrepresentative. As identified during the latter part of the sampling progress, the sand pump on the shale shaker was not running continuously while drilling. Retrieved sandy samples probably represent an admixture over an unspecified stratigraphic interval, rather than representing a discrete sand zone. Based on the rapid advance of the drill, the generation of sand waste, and the loss of drilling mud to the formation, sand zones in the interbeds appeared to be relatively unconsolidated. At no time were cuttings of cemented sands retrieved. Generally speaking, sands appeared to be only partially recovered by the drilling process.

The clay rich zones appeared to have squeezing properties, as evidenced by closing or partial closing of the borehole during drilling, reaming and geophysical logging. After initial drilling through an interbed, the hole was cemented, and then re-drilled. The remaining borehole cement column may be thin to non-existent in some intervals, as evidenced by retrieval of clay cuttings in cemented zones. Some of the squeezing zones had repetitive squeezing episodes. For some portions of the interbeds, the drillers reduced weight on the bit to avoid excessive bit advancement and potential for borehole deviation. The drillers tried to limit drill bit advance to15 to $20 \mathrm{ft} / \mathrm{hr}$. However, the drillers also noted a decreased rate of drilling in some clay intervals due to enhanced adhesive properties of those zones. The adhesive clay conditions required the drillers to take extra time to wash out the clay to avoid clogging the drill bit. The decreased drilling rate likely resulted from using a hard-formation button bit rather than a bit with coarse teeth for drilling in the soft formations. Very few recognizable cuttings particles were retrieved while drilling through the interbeds. 
WMP-32076 Rev. 0

\subsection{REFERENCES}

DOE/RL-0164, 1988, Site Characterization Plan, Consultation Draft, Reference Repository Location, Hanford Site, Washington, U. S. Department of Energy, Richland, Washington.

Freestone, 2006, Desk Instruction for Records Management to Support Waste Treatment PlantPNNL Seismic Boreholes Project, dated August 21, 2006, Freestone Environmental Services, Inc., Richland, Washington.

Gardner MG, KD Reynolds, and DE Skoglie. 2006. Drilling Plan for the Waste Treatment Plant Seismic Test Borehole Project. FS-RW-SWS-PN-005, Rev. 0, Duratek Federal Services, Richland, Washington.

GRP-EE-01-7.0, “Geologic Logging,” Revision 1, Fluor Hanford, Inc., Richland, Washington.

ICN 15848-1.1, 2006, Interim Change Notice, dated July 17, 2006, Pacific Northwest National Laboratory, Richland, Washington.

ICN 15848-2.1, 2006, Interim Change Notice, dated August 16, 2006, Pacific Northwest National Laboratory, Richland, Washington.

ICN 15848-2.2, 2006, Interim Change Notice, dated August 22, 2006, Pacific Northwest National Laboratory, Richland, Washington.

Myers CW et al. 1979. Geologic Studies of the Columbia Plateau-A Status Report. RHOBWI-ST-4, Rockwell Hanford Operations, Richland, Washington.

PNNL-15848a, 2006, Sampling and Analysis Plan Waste Treatment Plant Seismic Boreholes Project, Rev. 0, Pacific Northwest National Laboratory, Richland, Washington.

PNNL-15848b, 2006, Sampling and Analysis Plan Waste Treatment Plant Seismic Boreholes Project, Rev. 1a, Pacific Northwest National Laboratory, Richland, Washington.

PNNL-15848c, 2006, Sampling and Analysis Plan Waste Treatment Plant Seismic Boreholes Project, Rev. 2, Pacific Northwest National Laboratory, Richland, Washington. 
WMP-32076 Rev. 0

This page intentionally left blank 
WMP-32076 Rev. 0

APPENDIX A

BOREHOLE LOG FOR C4996 
WMP-32076 Rev. 0

This page intentionally left blank

A-ii 
WMP-32076 Rev. 0

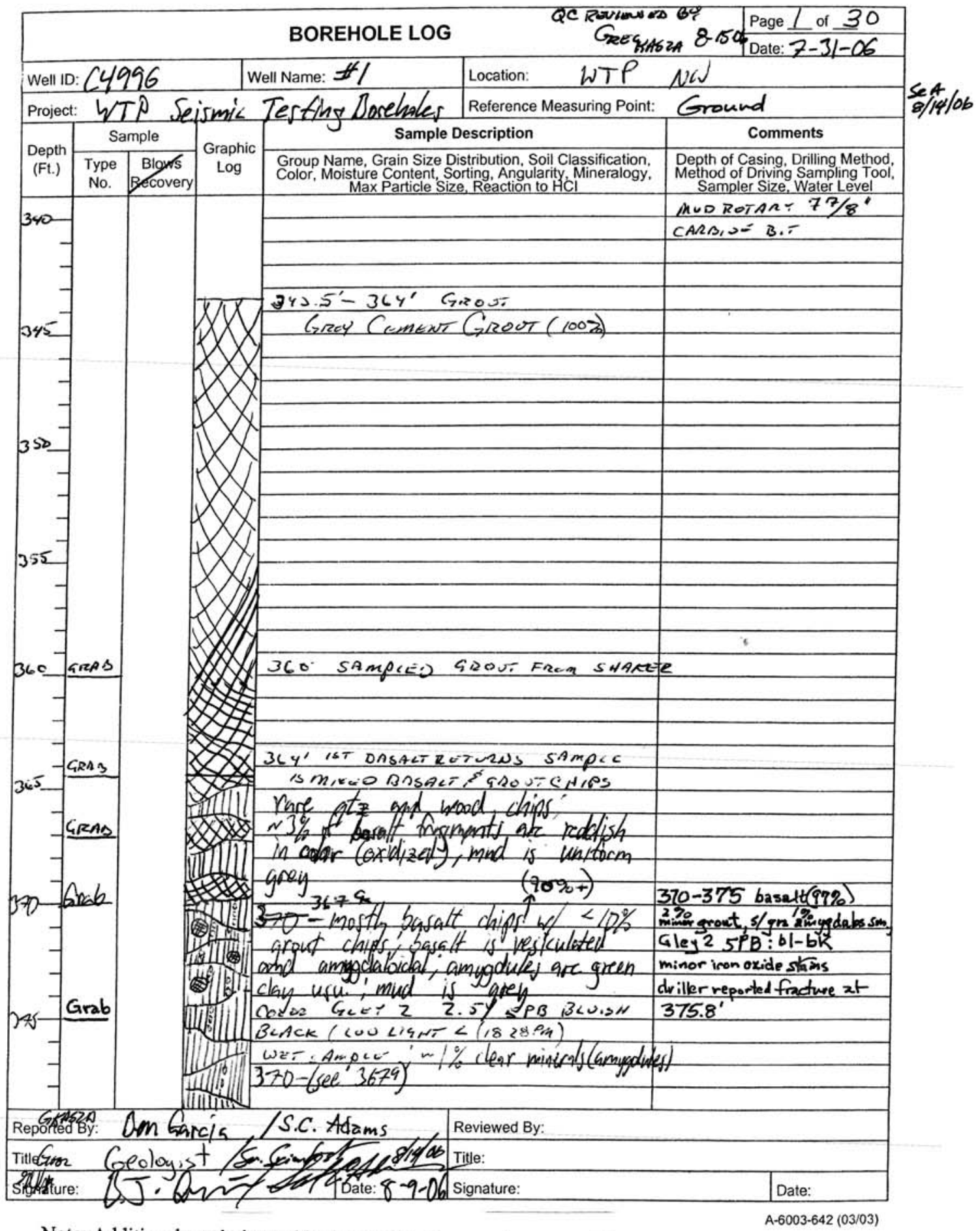

Note: Additional symbols used in the Graphic Log are documented in Appendix of PNNL-15848, Revision 2 CR 8/9/06 
WMP-32076 Rev. 0

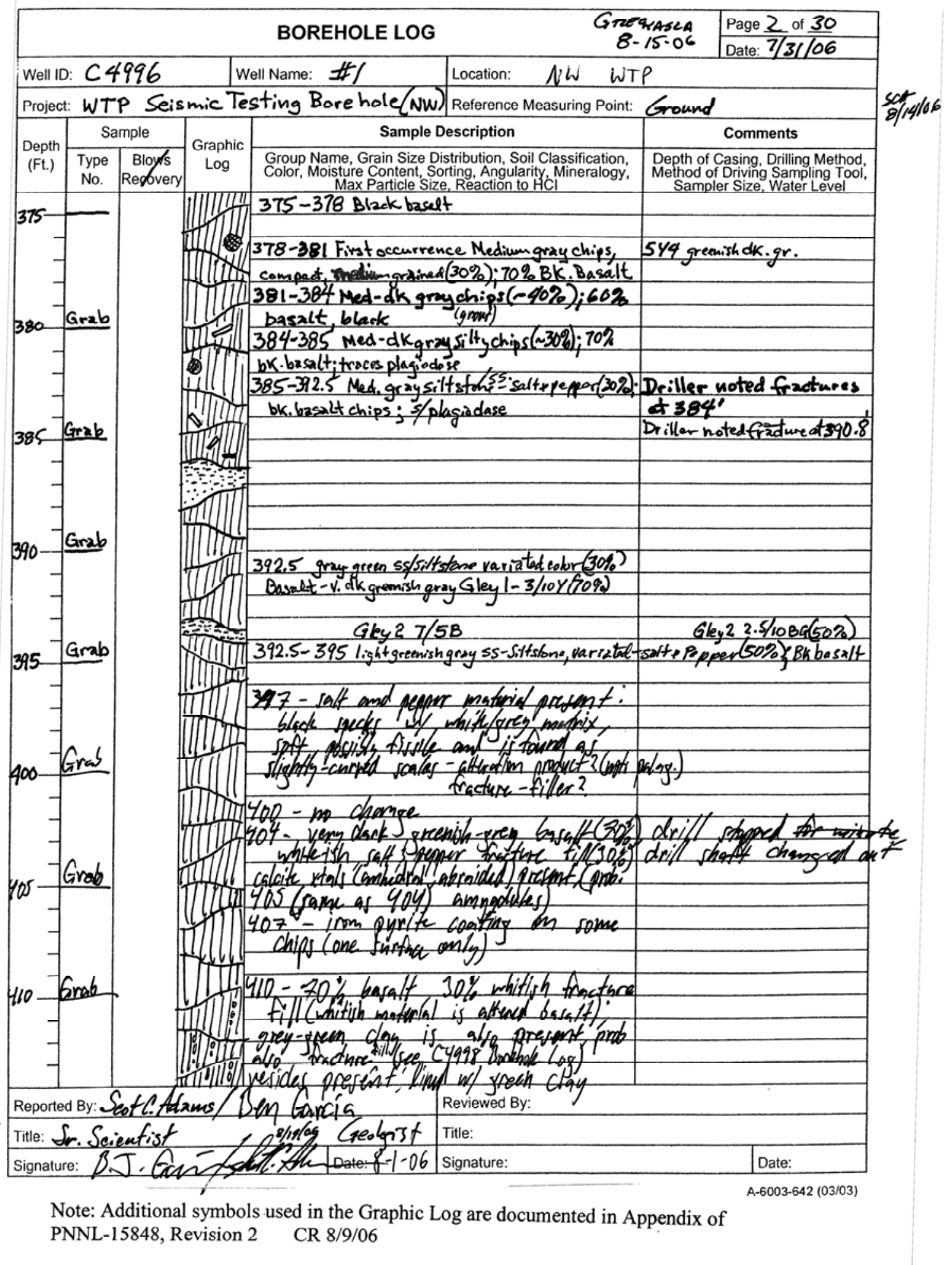


WMP-32076 Rev. 0

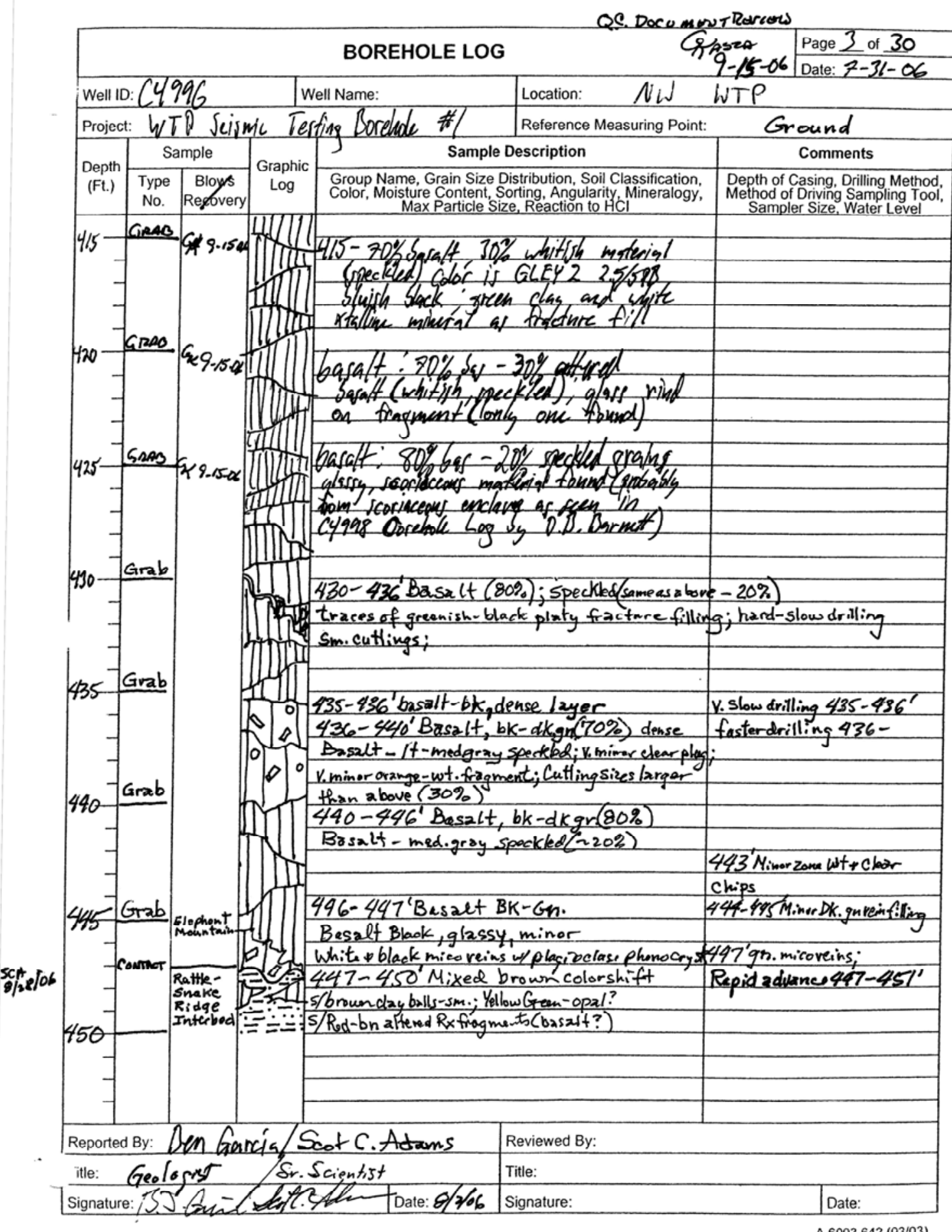

Note: Additional symbols used in the Graphic Log are documented in Appendix of PNNL-15848, Revision 2 CR 8/9/06 
WMP-32076 Rev. 0

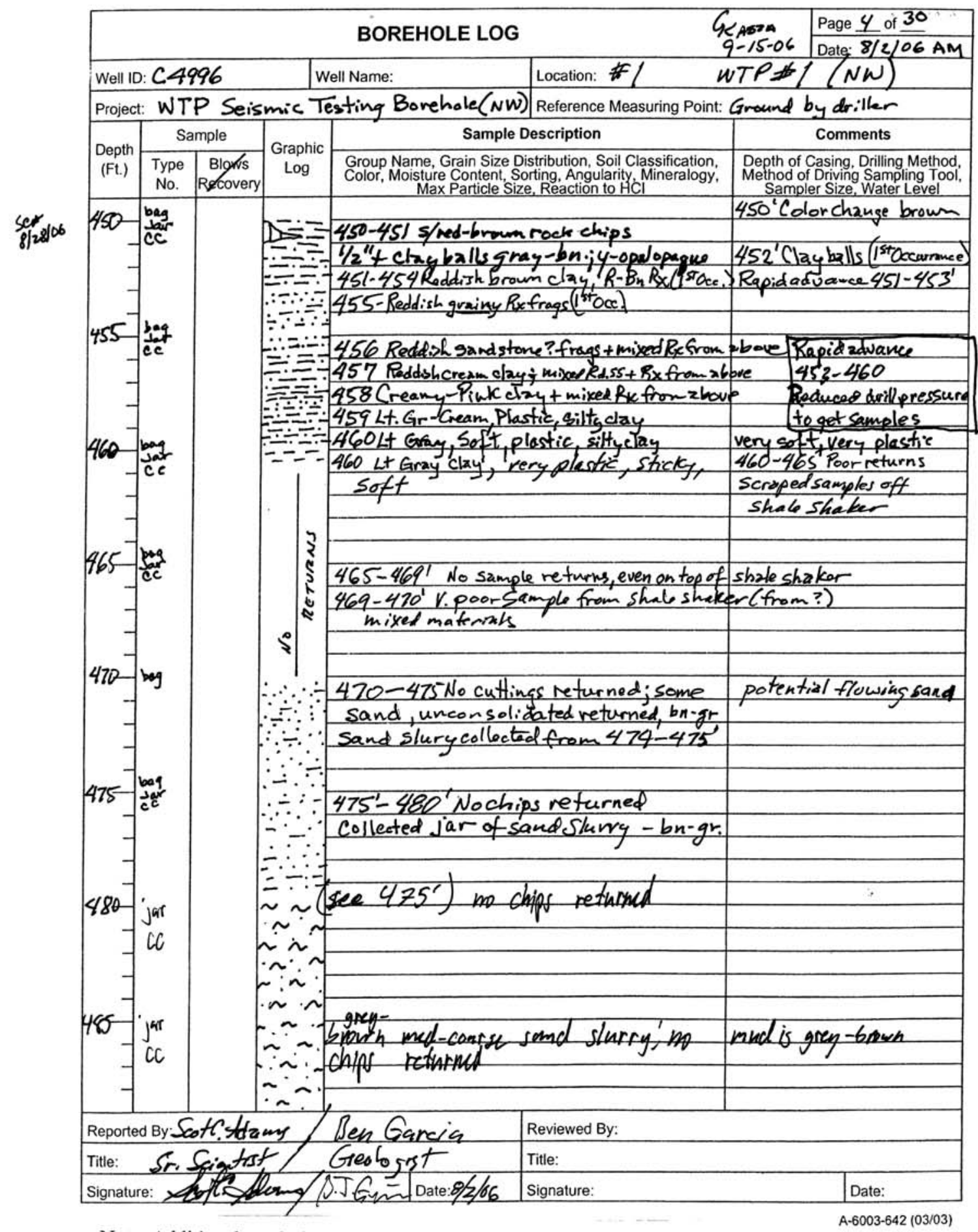

Note: Additional symbols used in the Graphic Log are documented in Appendix of PNNL-15848, Revision 2 CR 8/9/06 
WMP-32076 Rev. 0

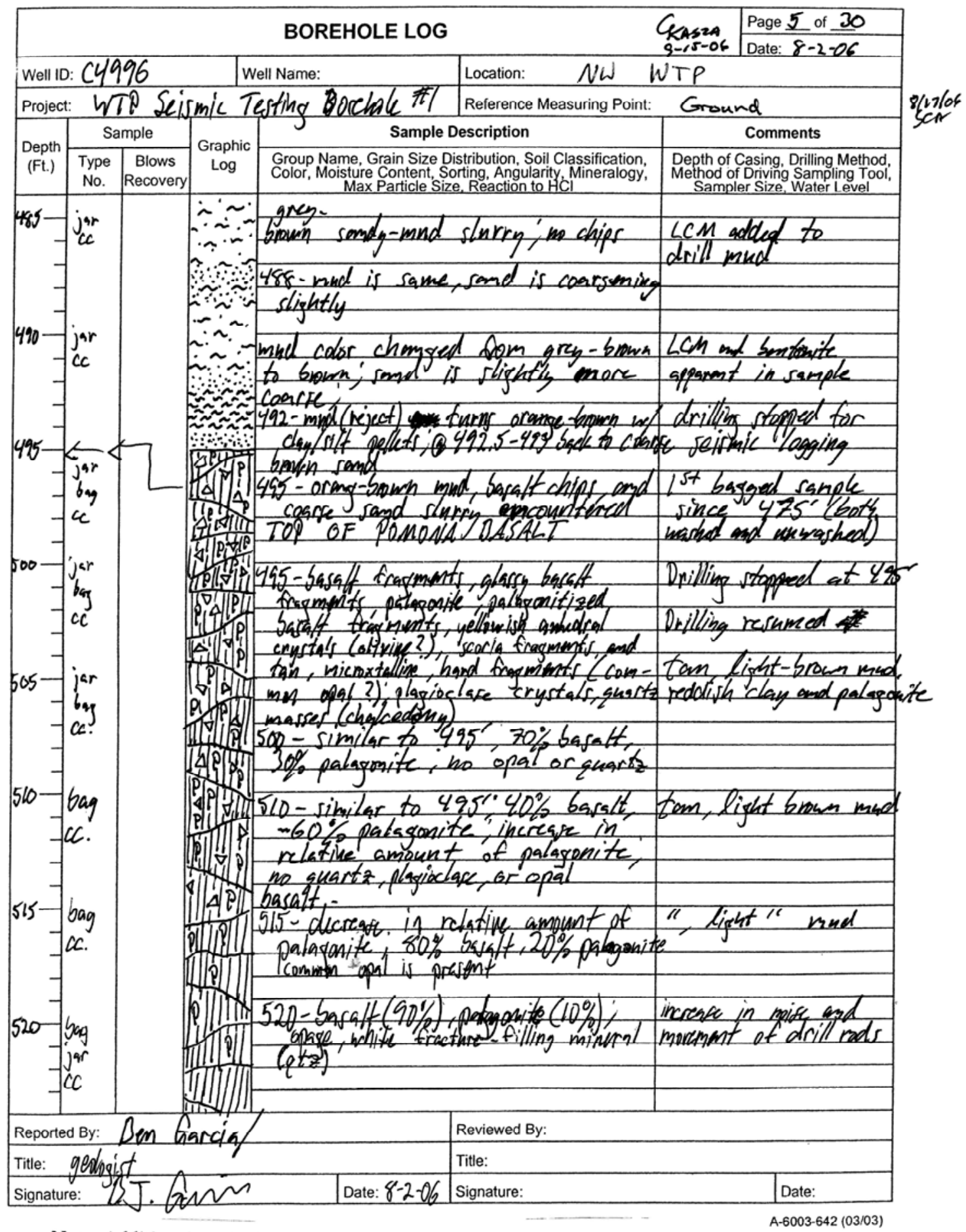

Note: Additional symbols used in the Graphic Log are documented in Appendix of PNNL-15848, Revision 2 CR 8/9/06 
WMP-32076 Rev. 0

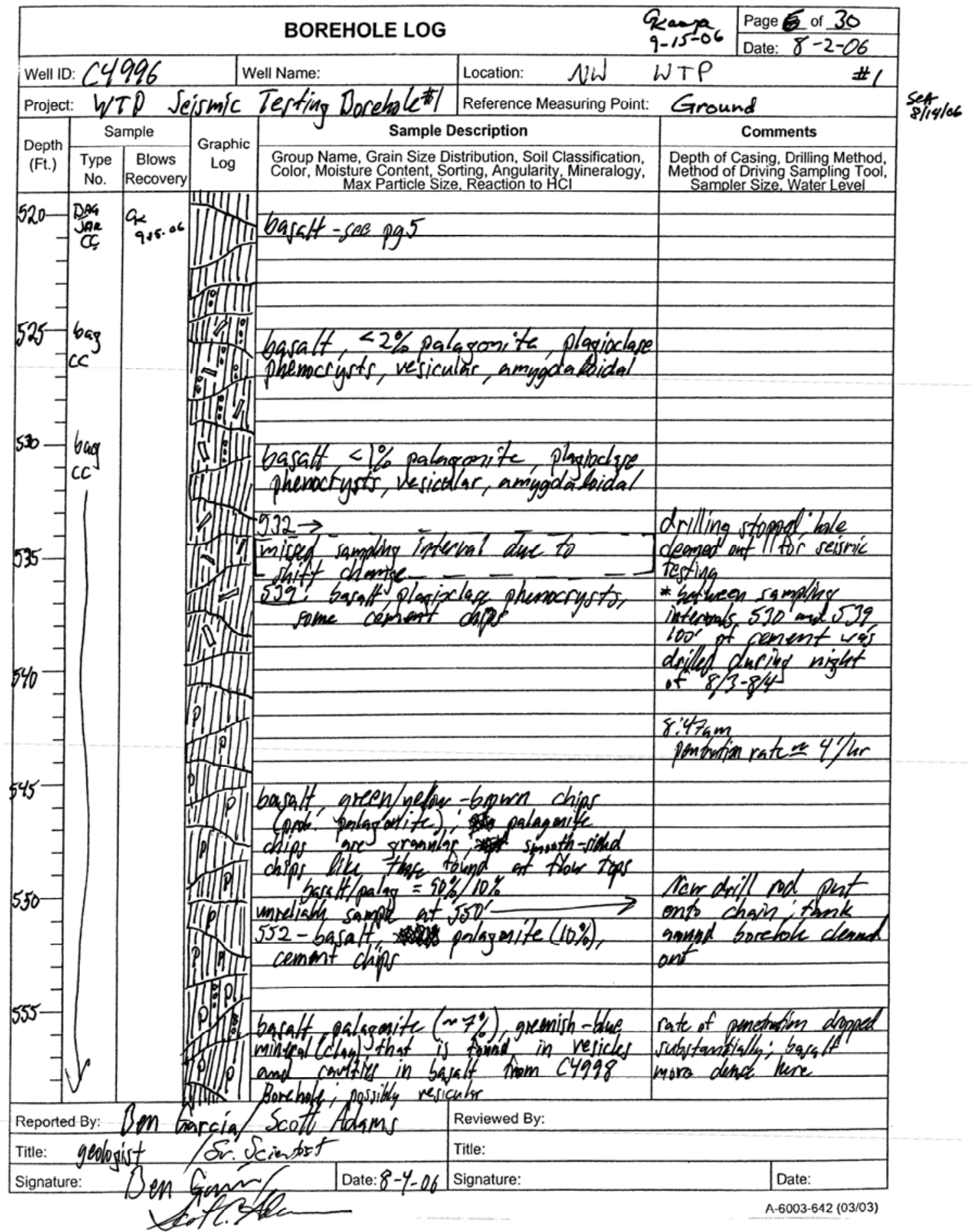

Note: Additional symbols used in the Graphic Log are documented in Appendix c PNNL-15848. Revision 2 CR 8/9/06 
WMP-32076 Rev. 0

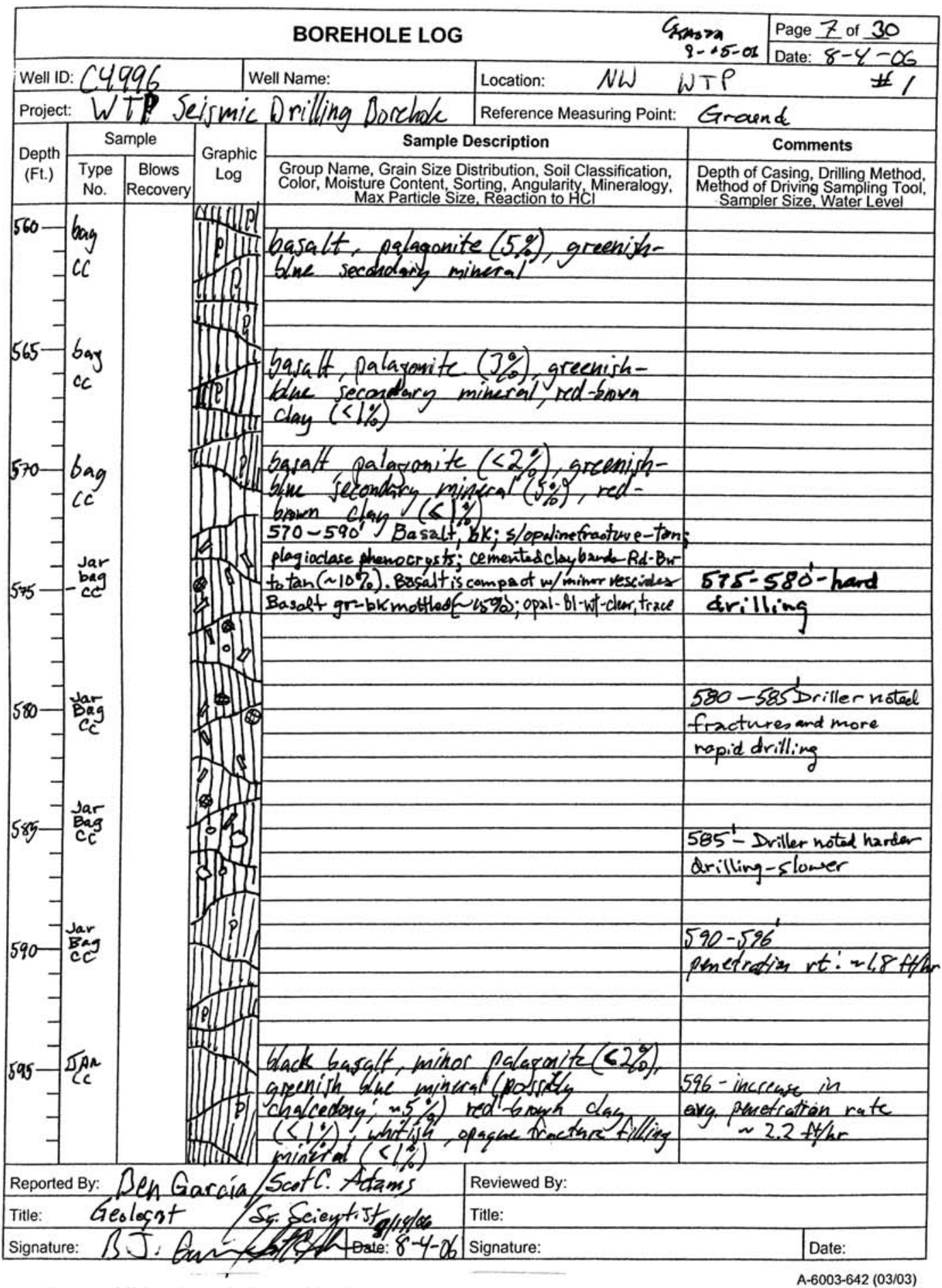

Note: Additional symbols used in the Graphic Log are documented in Appendix of PNNL-15848, Revision 2 CR 8/9/06 
WMP-32076 Rev. 0

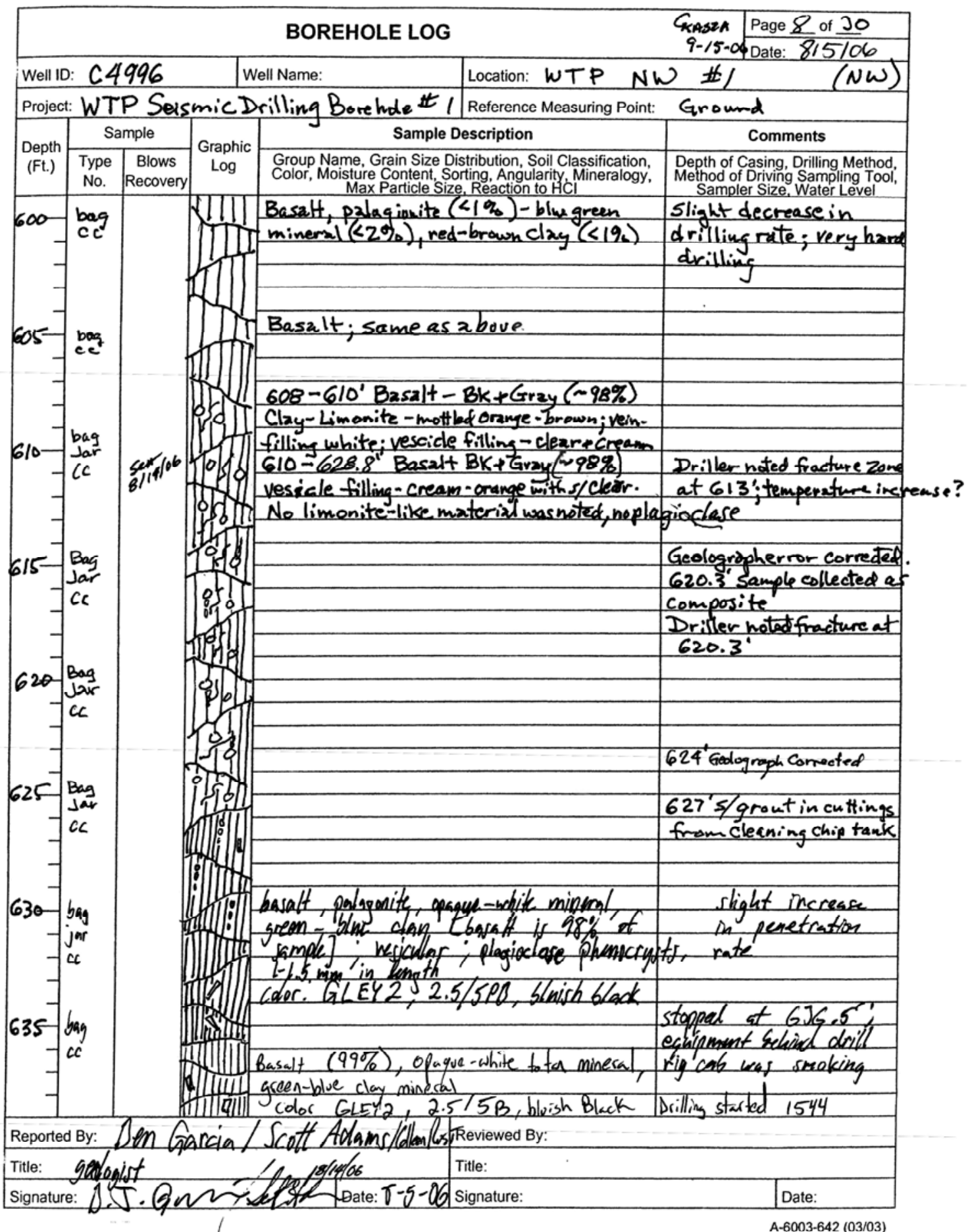

Note: Additional symbols used in the Graphic Log are documented in Appendix of PNNL-15848, Revision 2 CR 8/9/06 
WMP-32076 Rev. 0

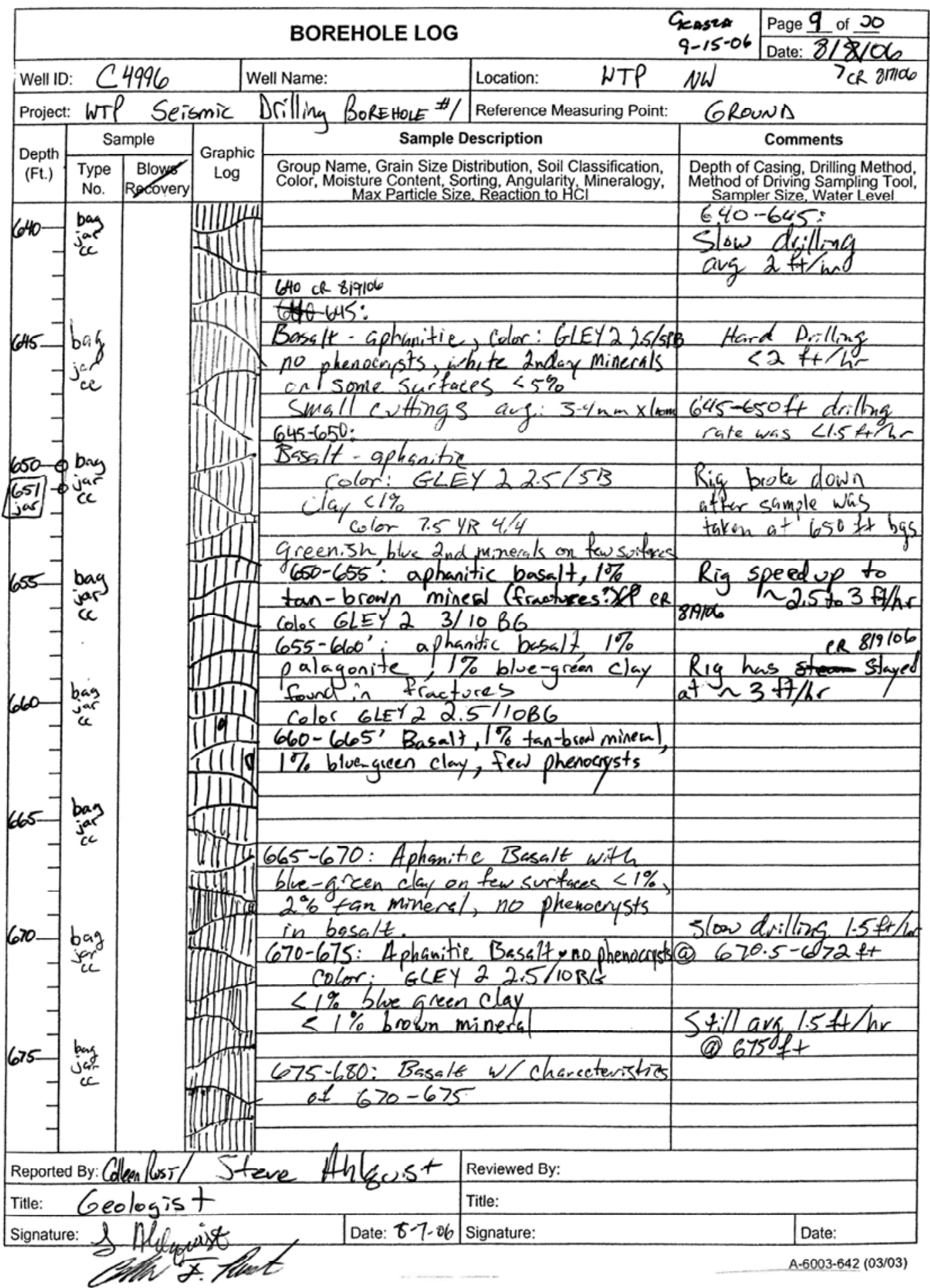

Note: Additional symbols used in the Graphic Log are documented in Appendix of PNNI_-1 5848. Revision 2 CR 8/9/06 
WMP-32076 Rev. 0

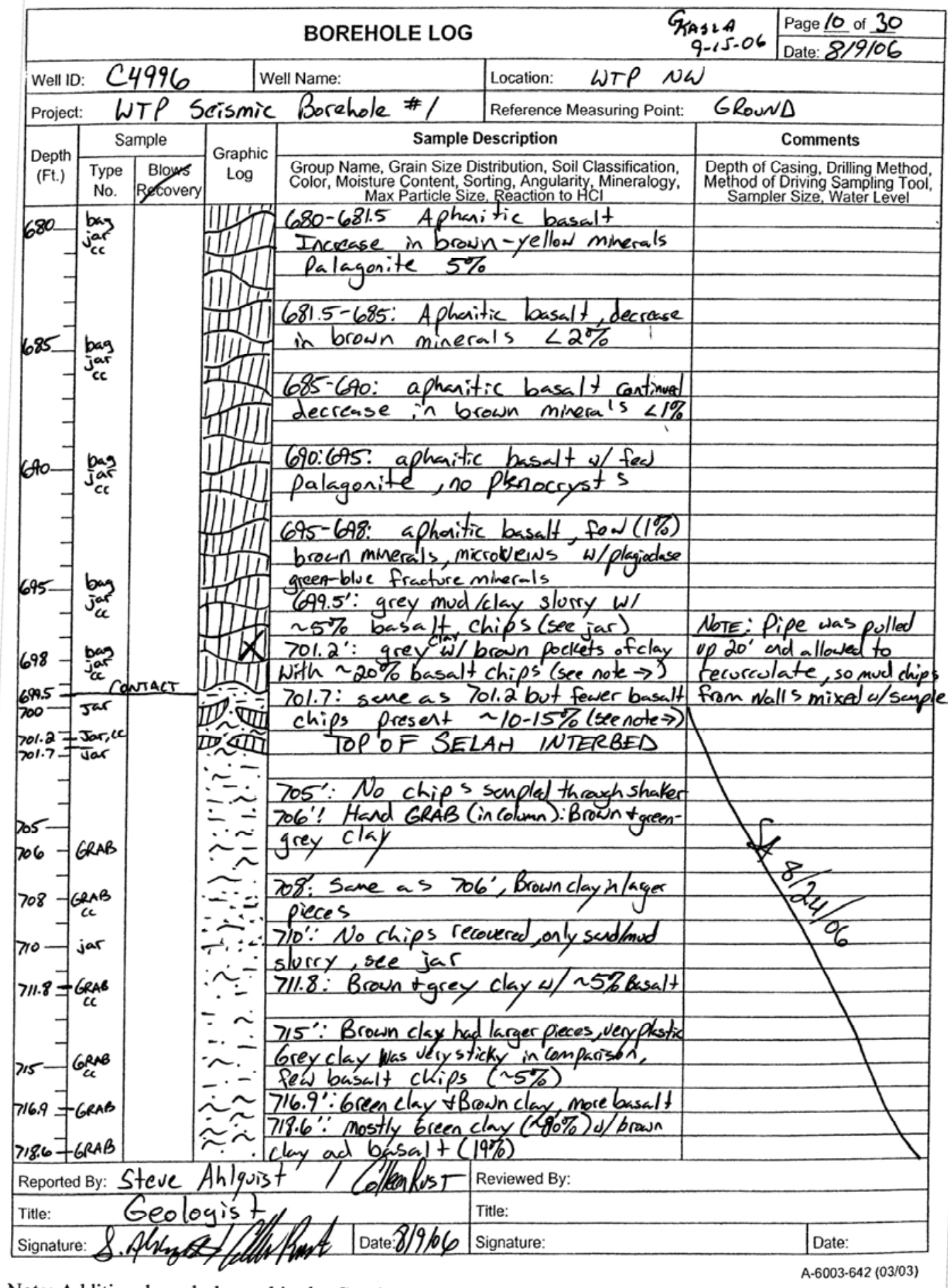

Note: Additional symbols used in the Graphic Log are documented in Appendix of PNNL-15848, Revision 2 CR 8/9/06 
WMP-32076 Rev. 0

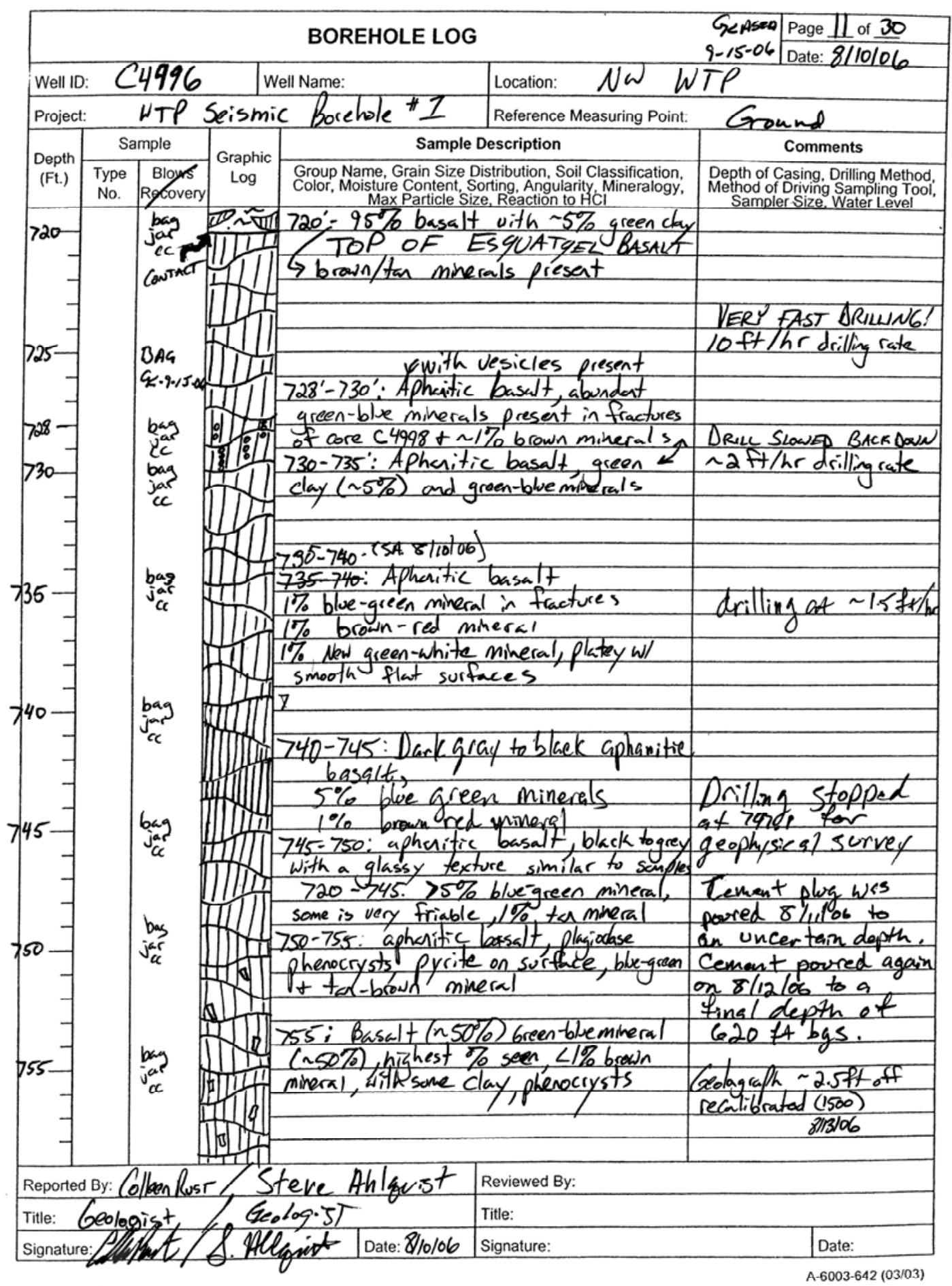

Note: Additional symbols used in the Graphic Log are documented in Appendix of PNNL-15848, Revision 2 CR 8/9/06 
WMP-32076 Rev. 0

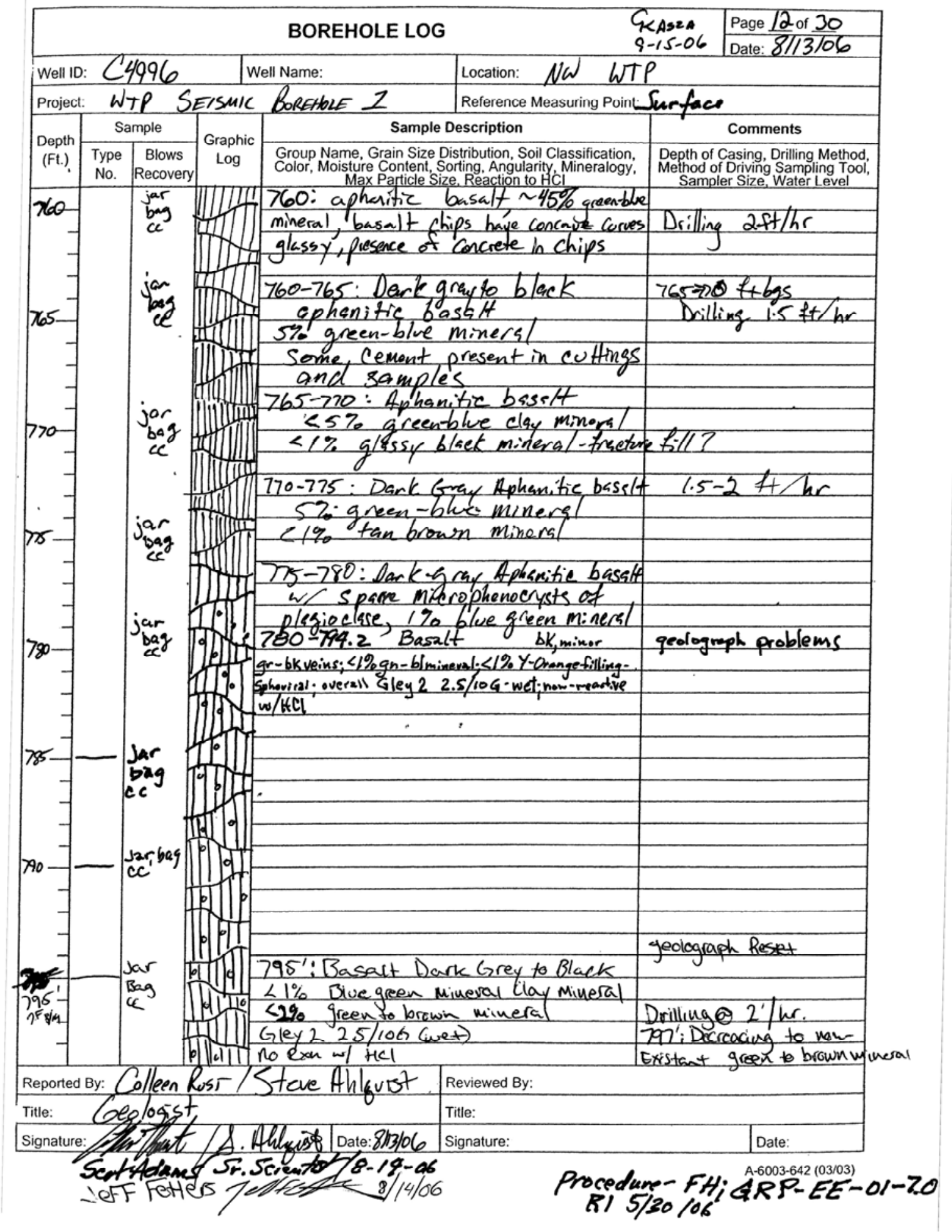


WMP-32076 Rev. 0

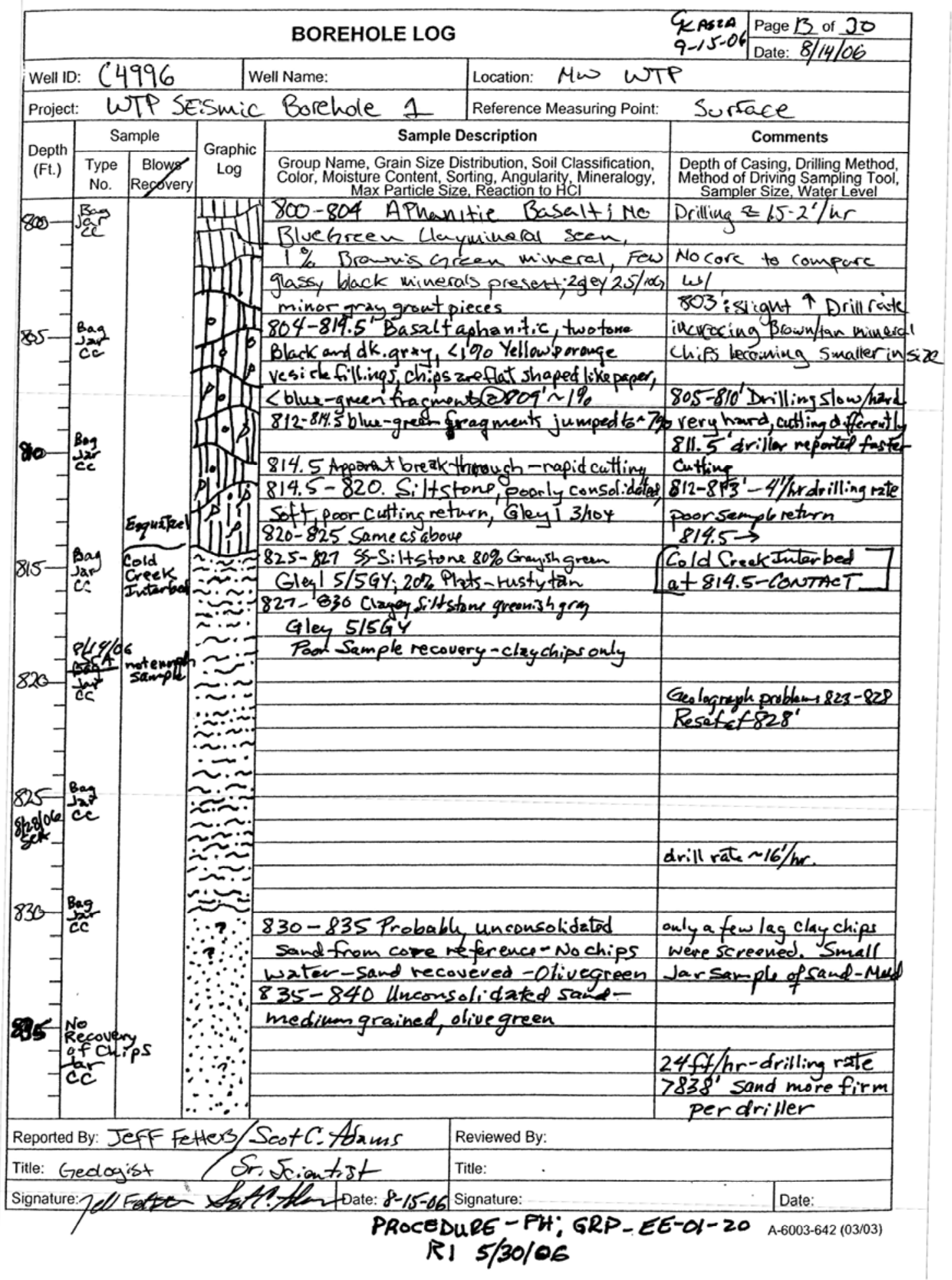




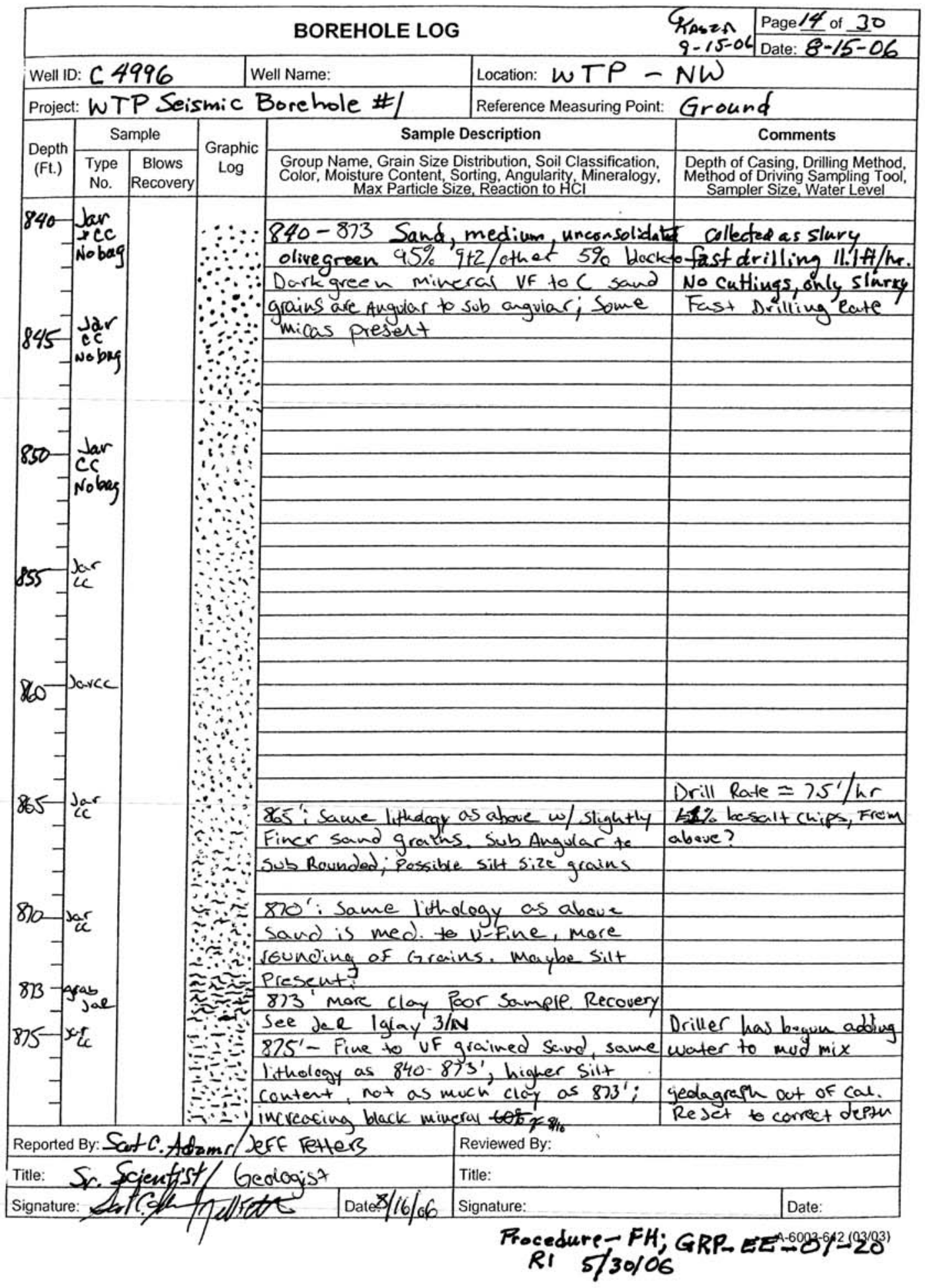


WMP-32076 Rev. 0

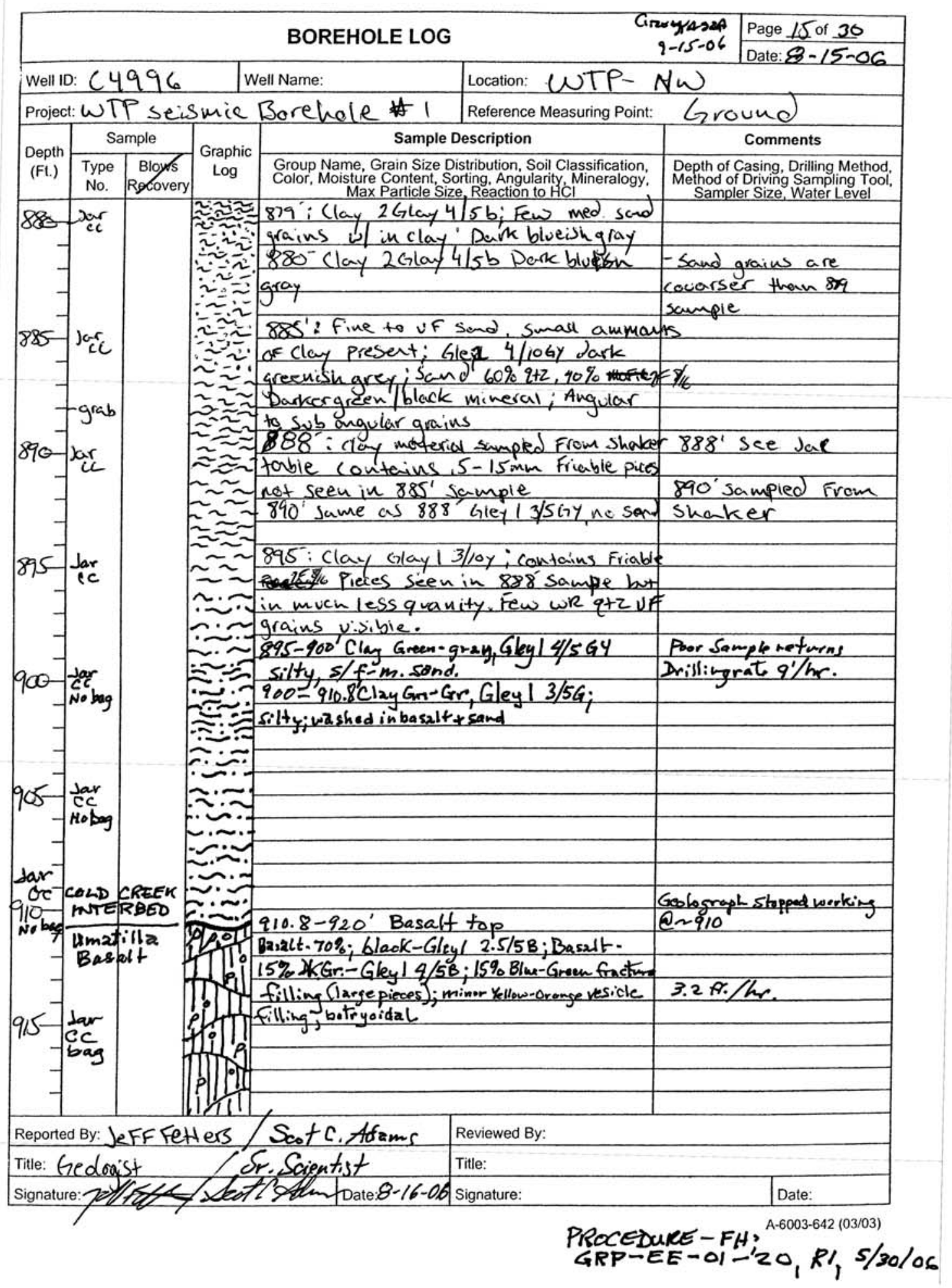


WMP-32076 Rev. 0

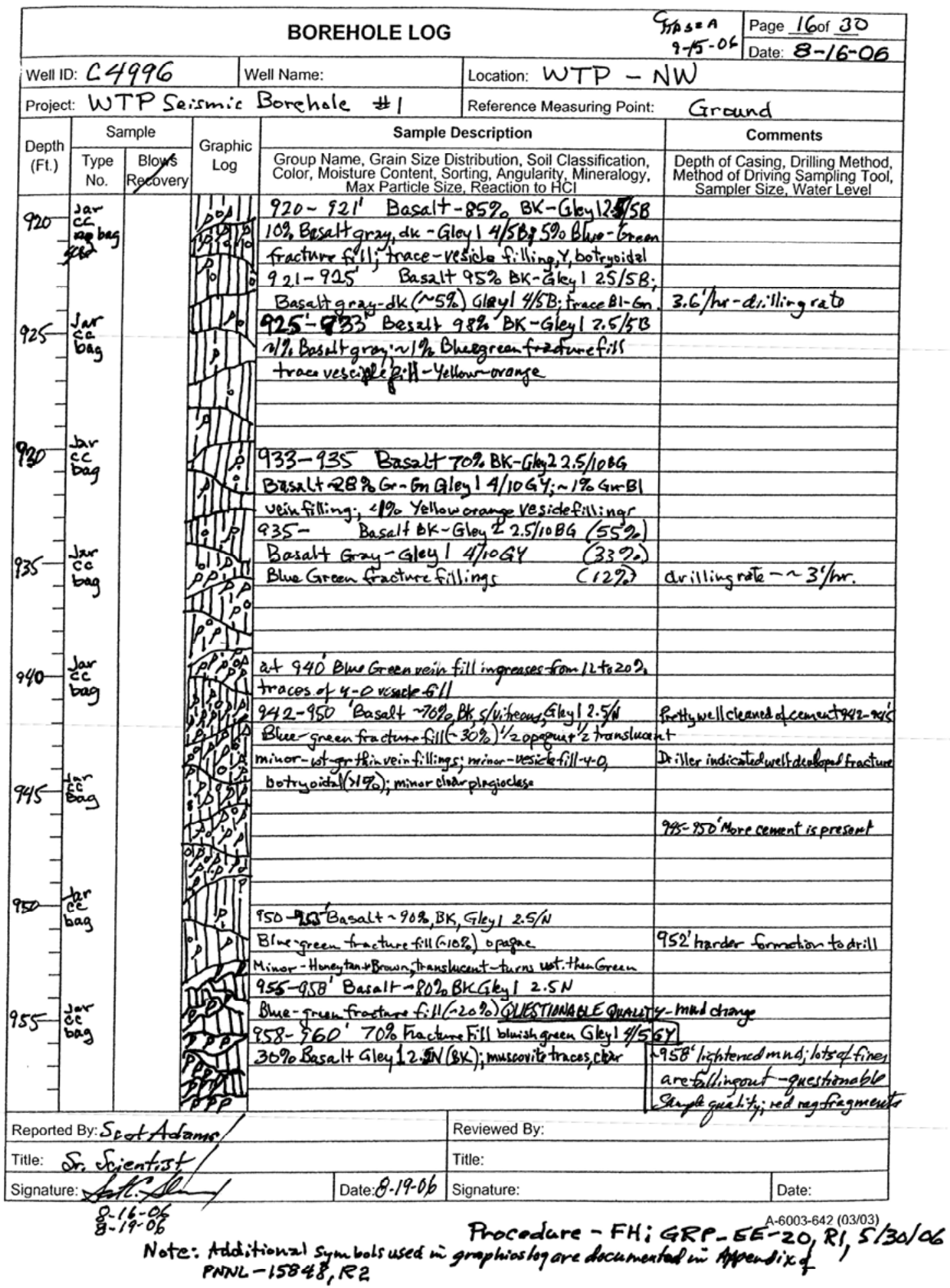


WMP-32076 Rev. 0

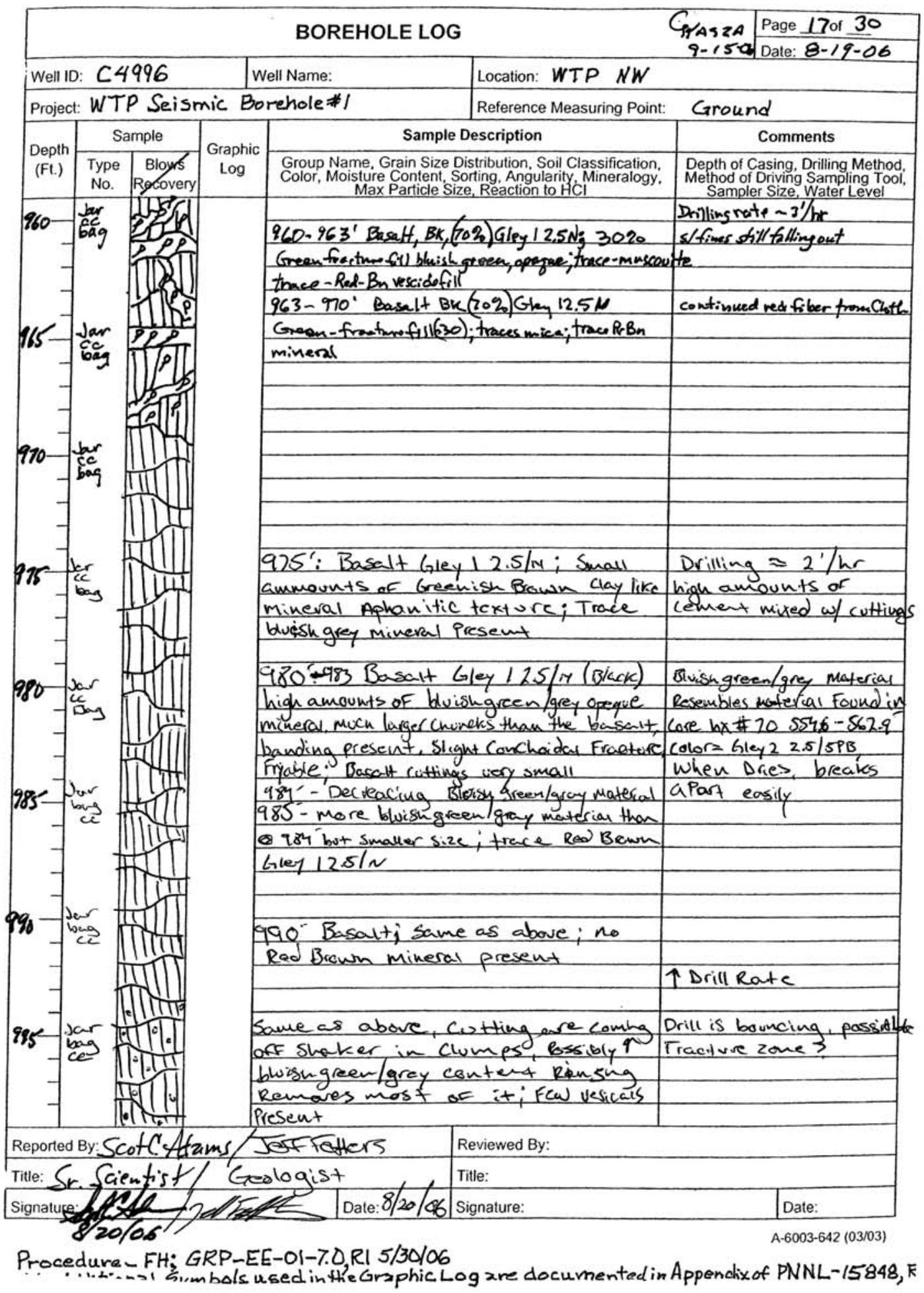


WMP-32076 Rev. 0

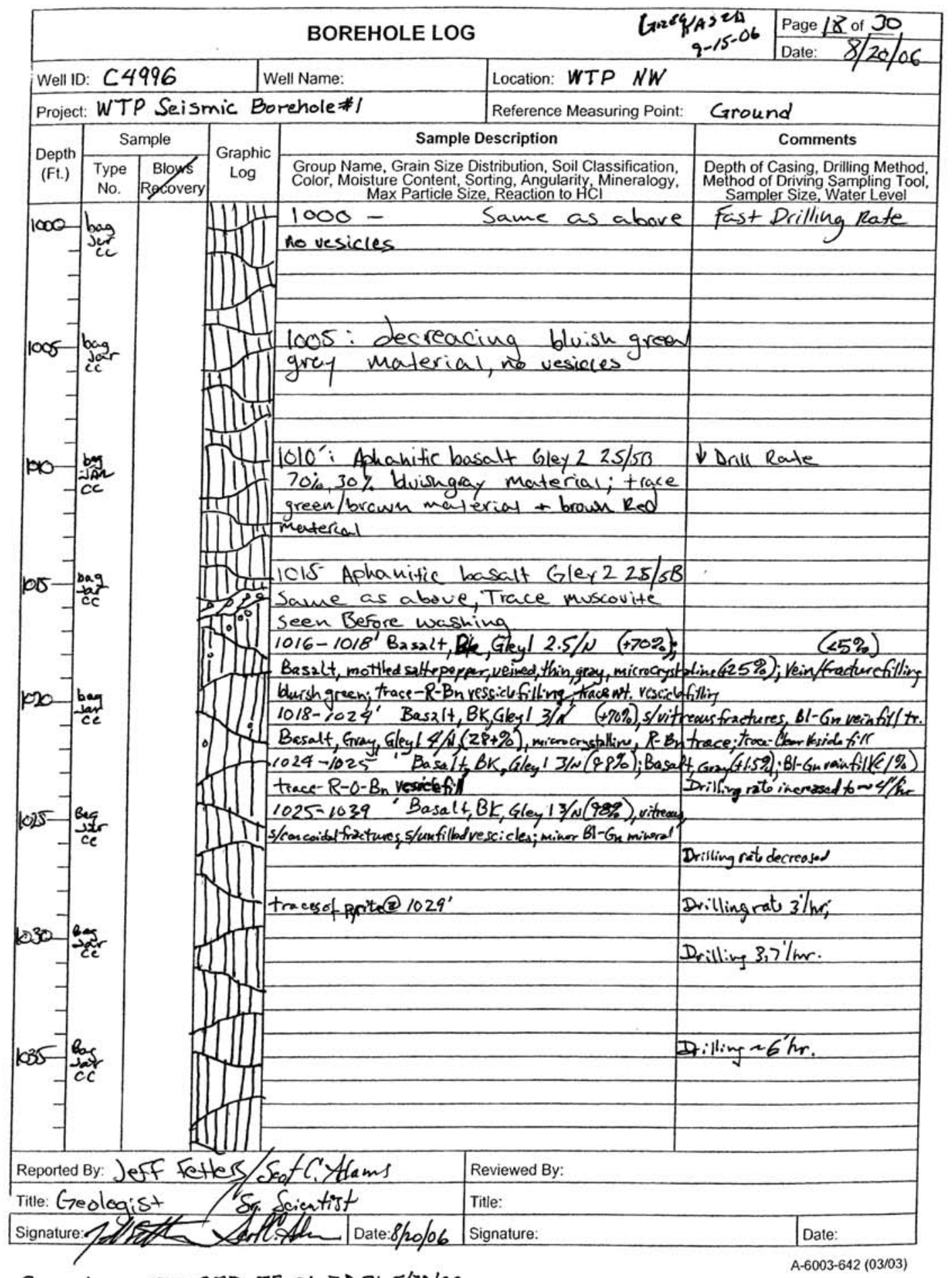

Procedure- FH; GRP-EE-OI-7.0,RI 5/30/06

.1. 11.tinnal Sumbols used in the Graphic Log are documented in Appendix of PNNL-15848, R 
WMP-32076 Rev. 0

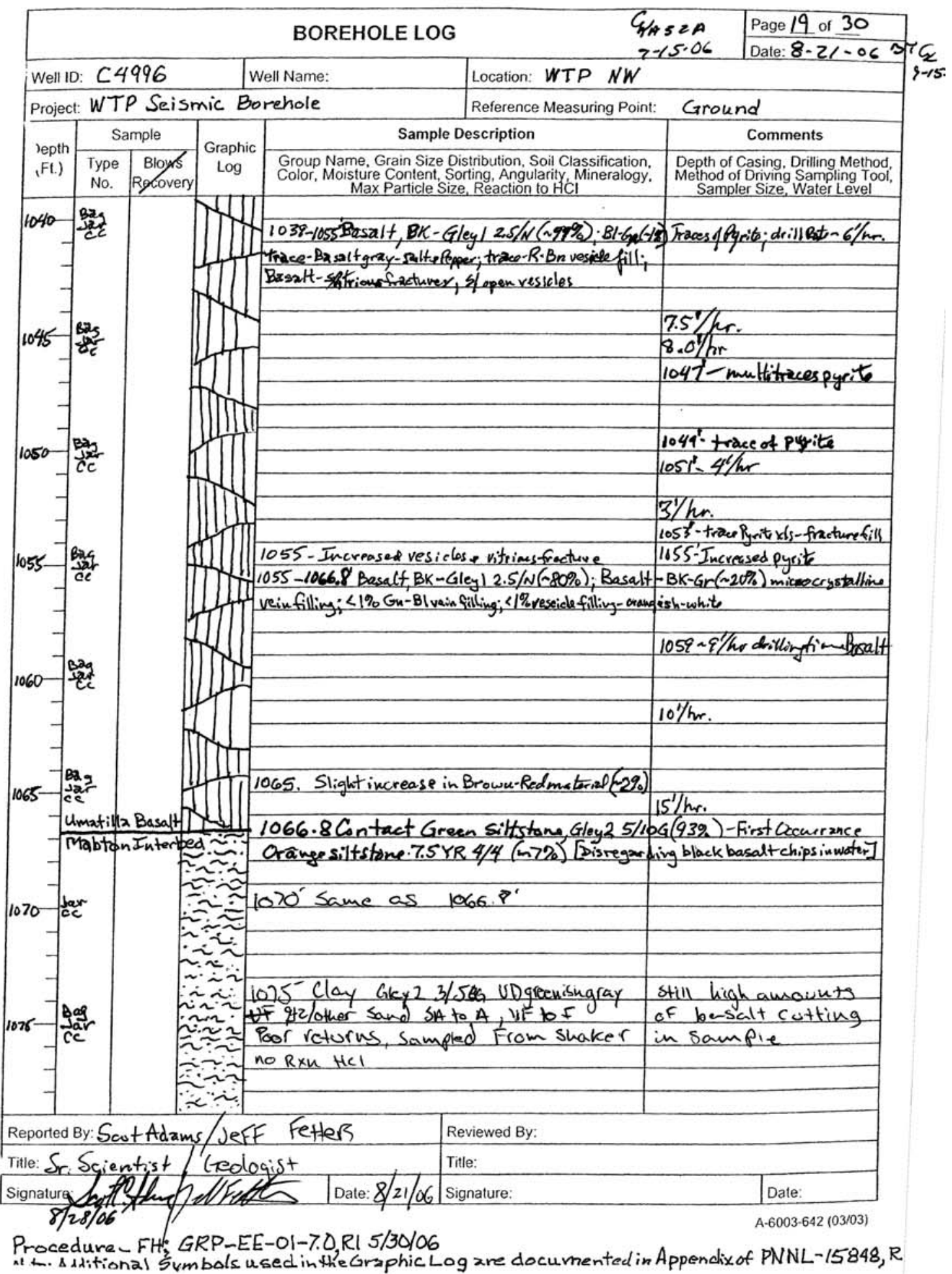


WMP-32076 Rev. 0

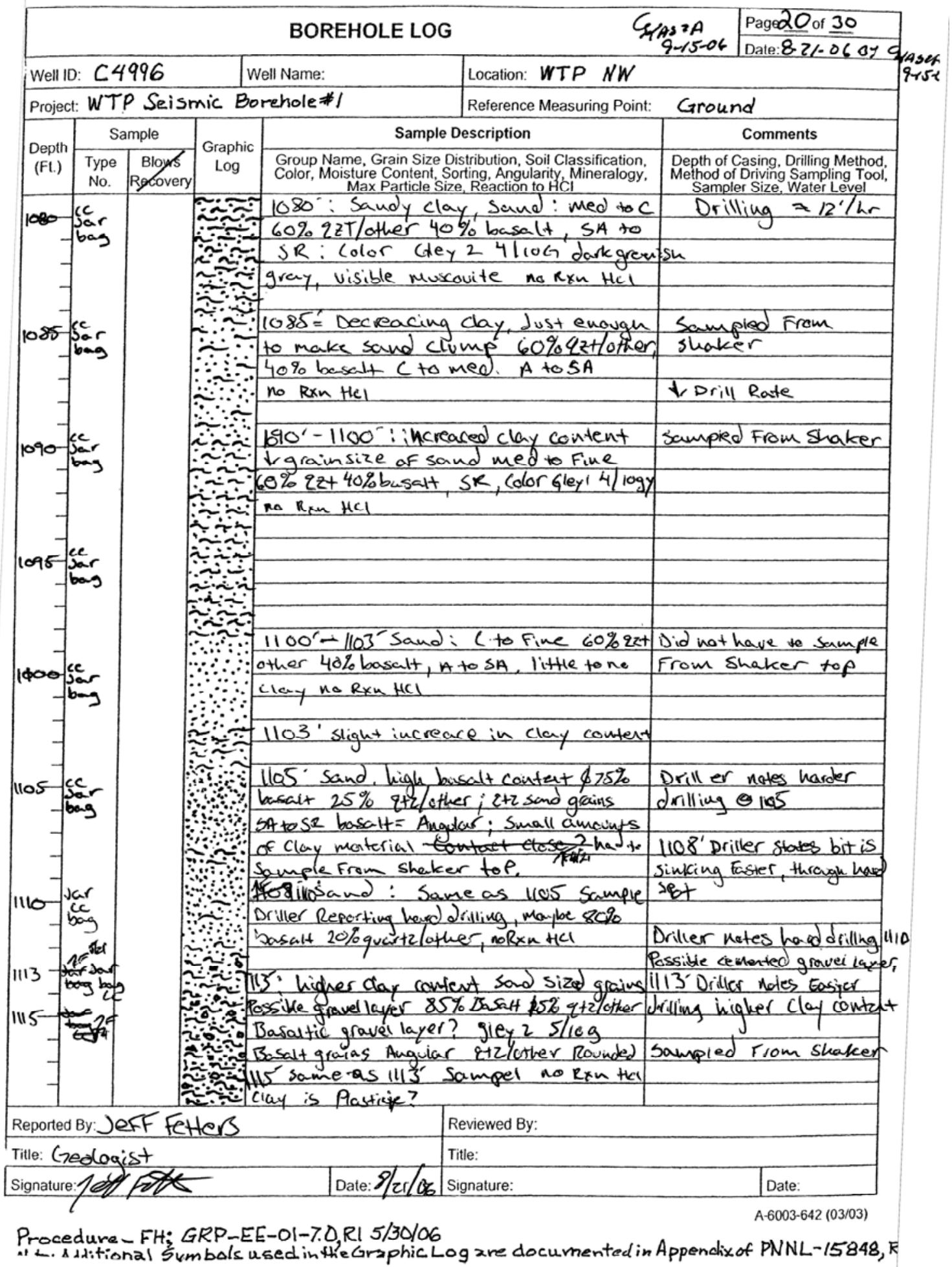


WMP-32076 Rev. 0

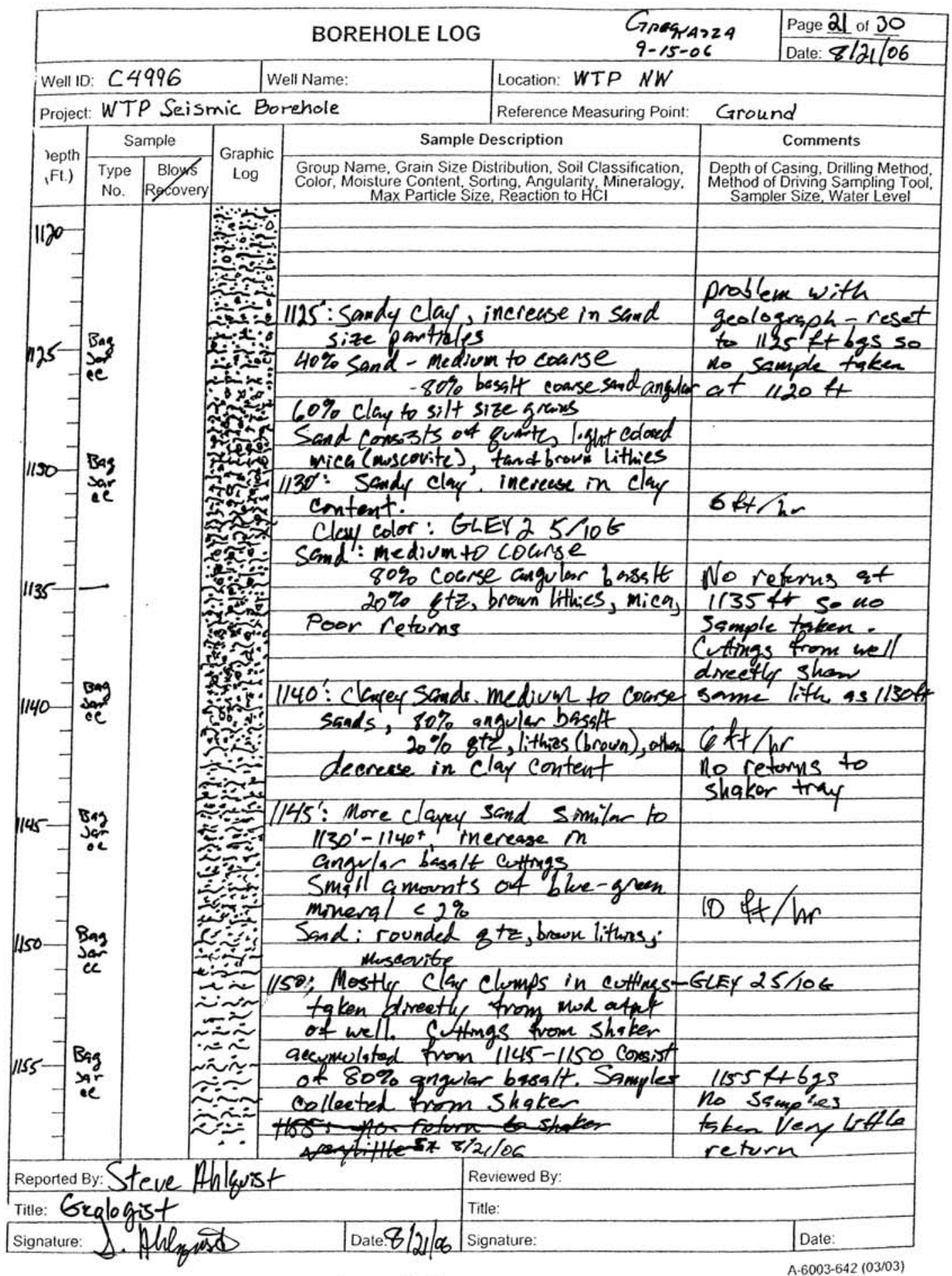

Procedure- FH; GRP-EE-OI-7.D,RI 5/30/06

A.6003-642 (03/03)

it in. Aditional Sumbols used in the Graphic Log are documented in Appendix of PNNL-15848, R2 
WMP-32076 Rev. 0

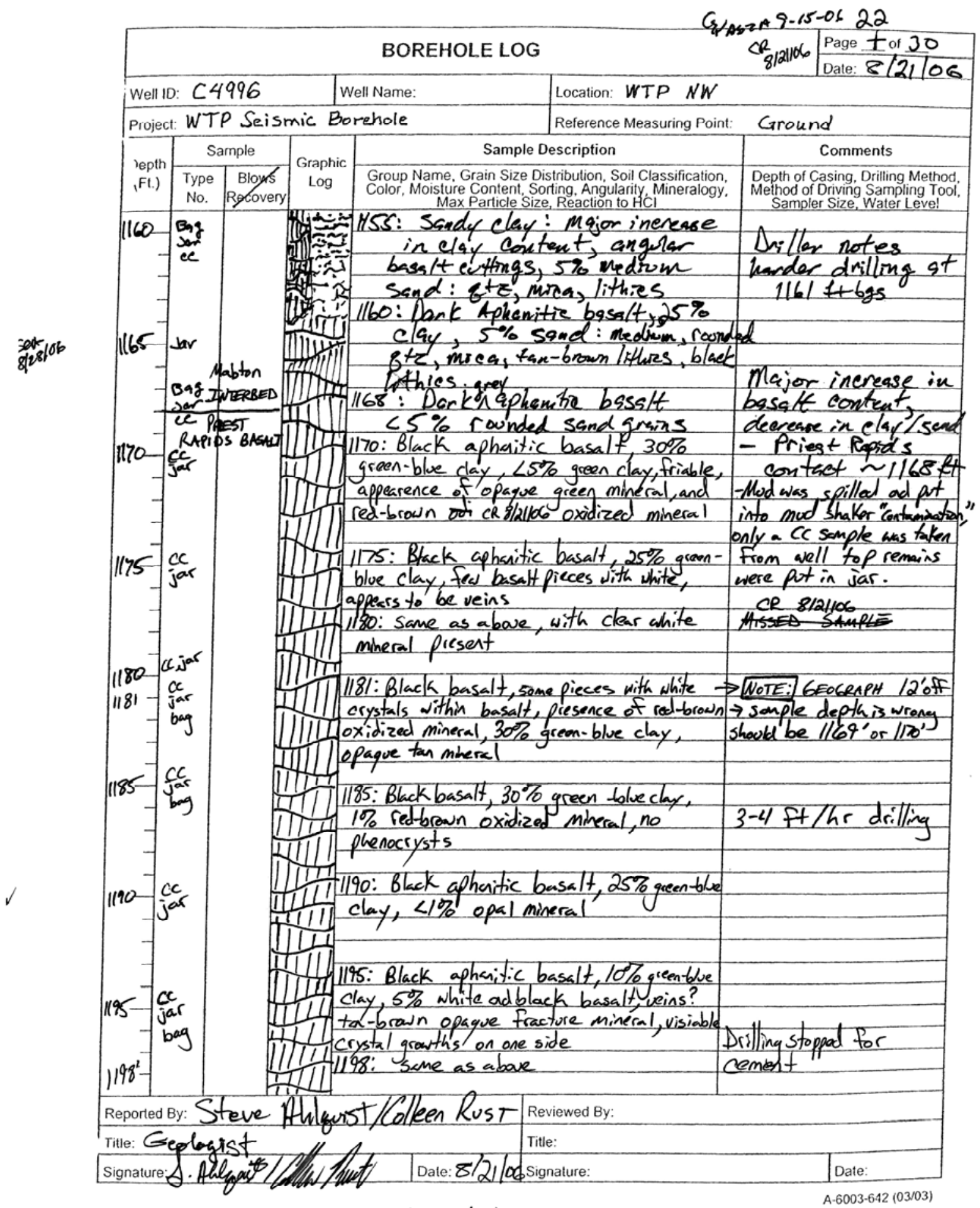

Procedure- FH; GRP-EE-OI-7.D,RI 5/30/06

A-6003-642 (03/03)

Atutr. Additional Symbols used in the Graphic Log are documented in Appendix of PNNL-15848, R.2 
WMP-32076 Rev. 0

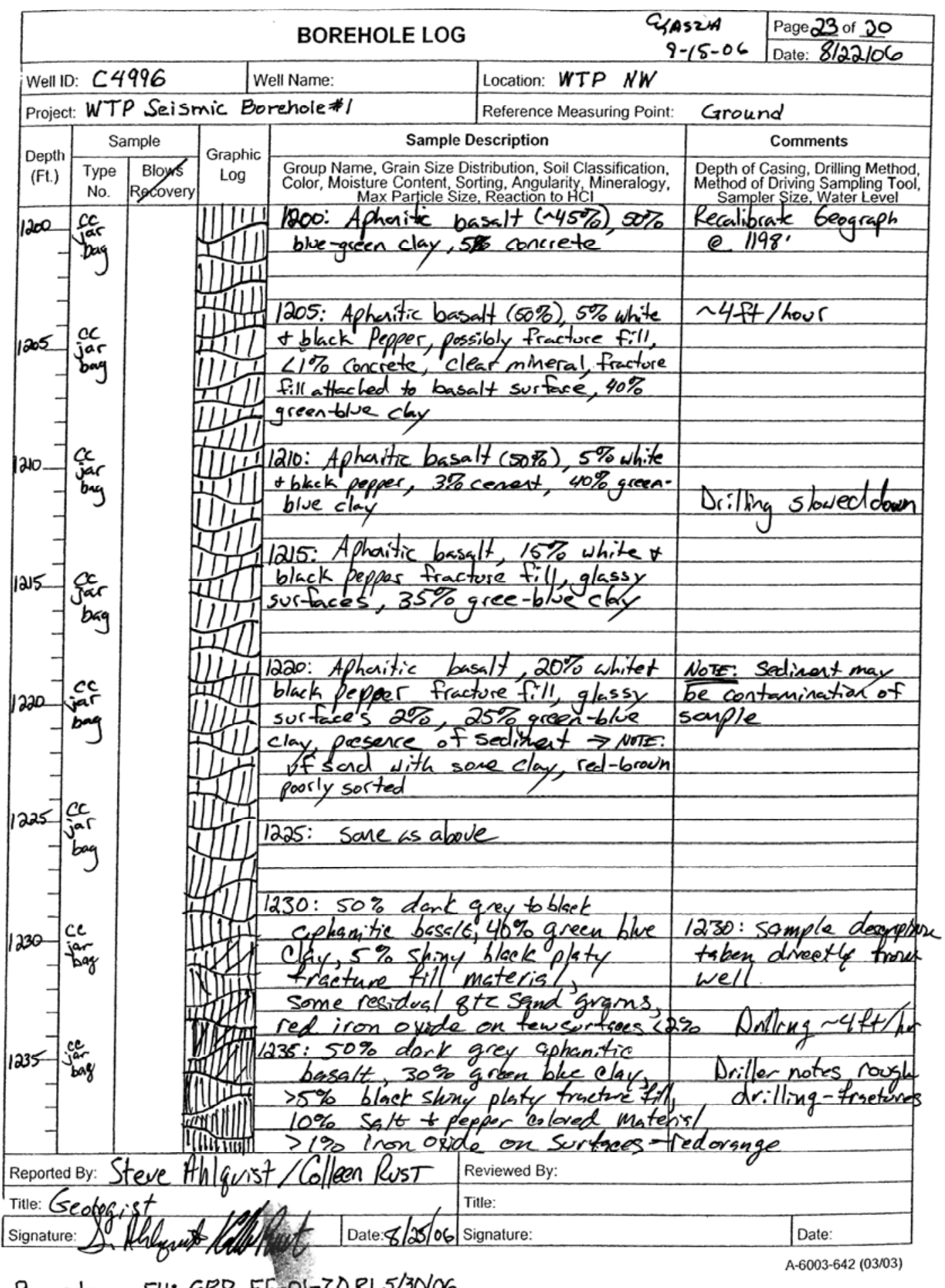

Procedure- FH; GRP-EE-OI-7.0,RI 5/30/06

rocedure 
WMP-32076 Rev. 0

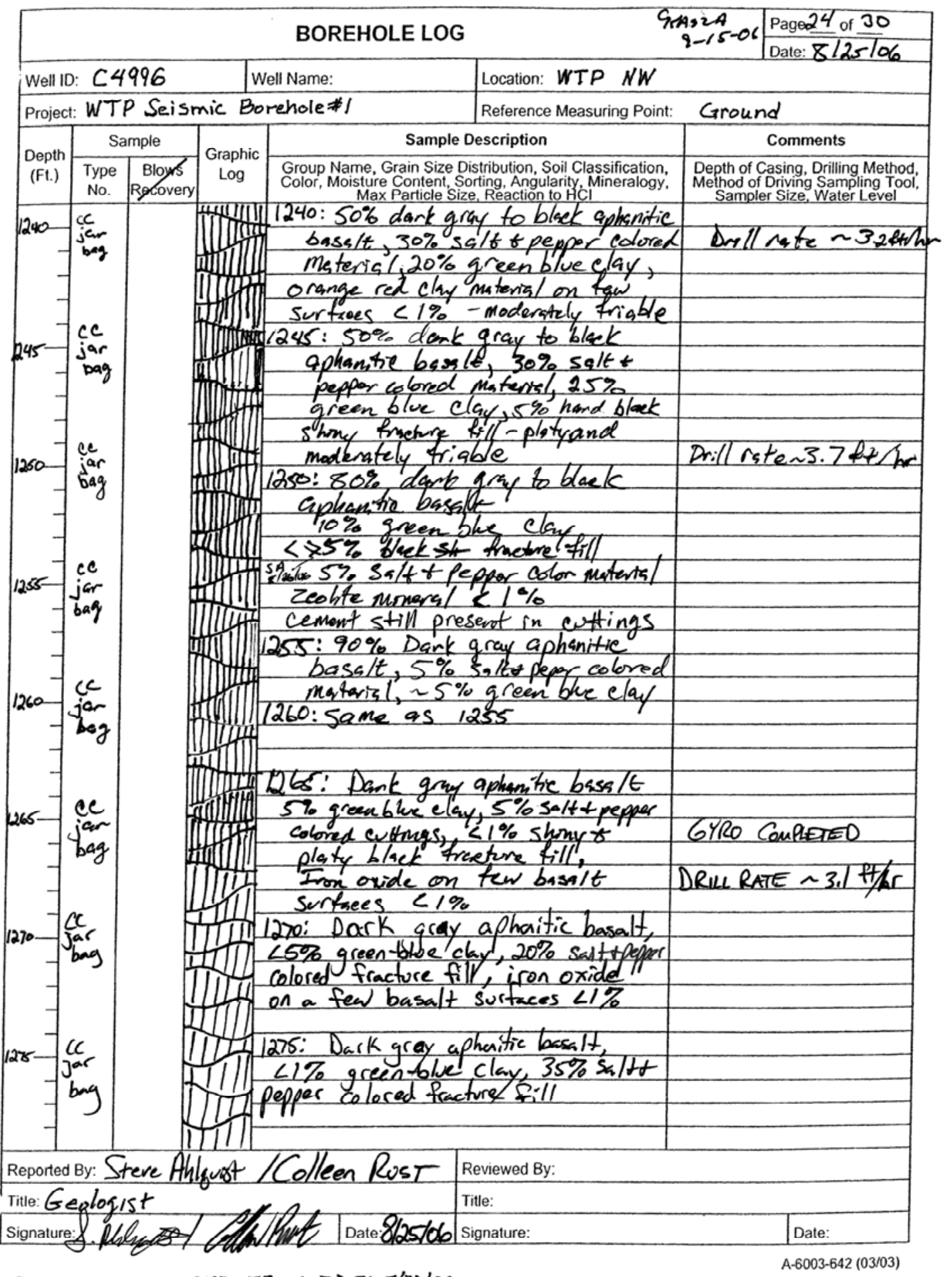

Procedure - FH; GRP-EE-OI-7.0 RI 5/30/06

at... Adtitional Sumbols used in the Graphic Log are documented in Appendix of PNNL-15848, R 
WMP-32076 Rev. 0

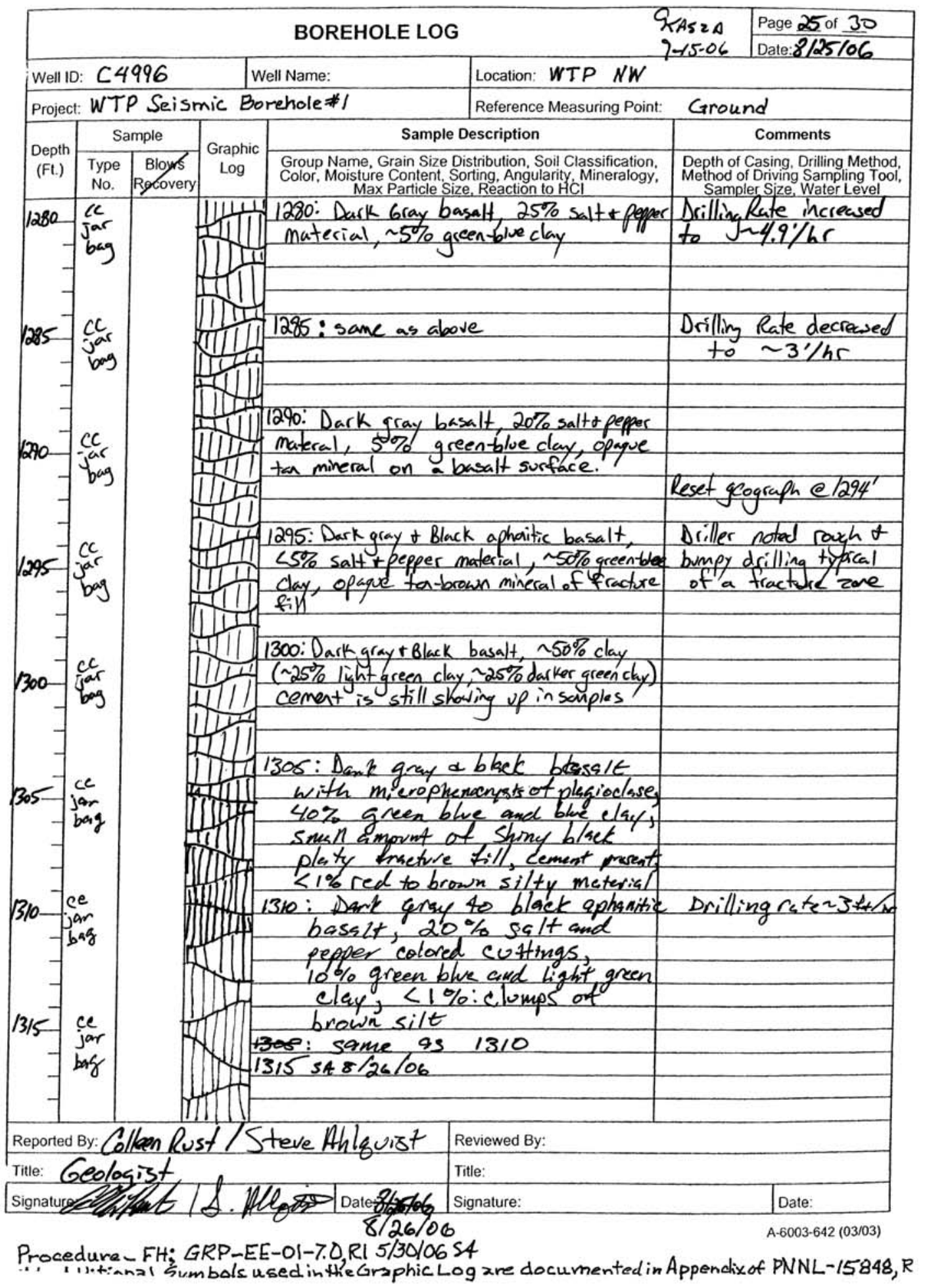


WMP-32076 Rev. 0

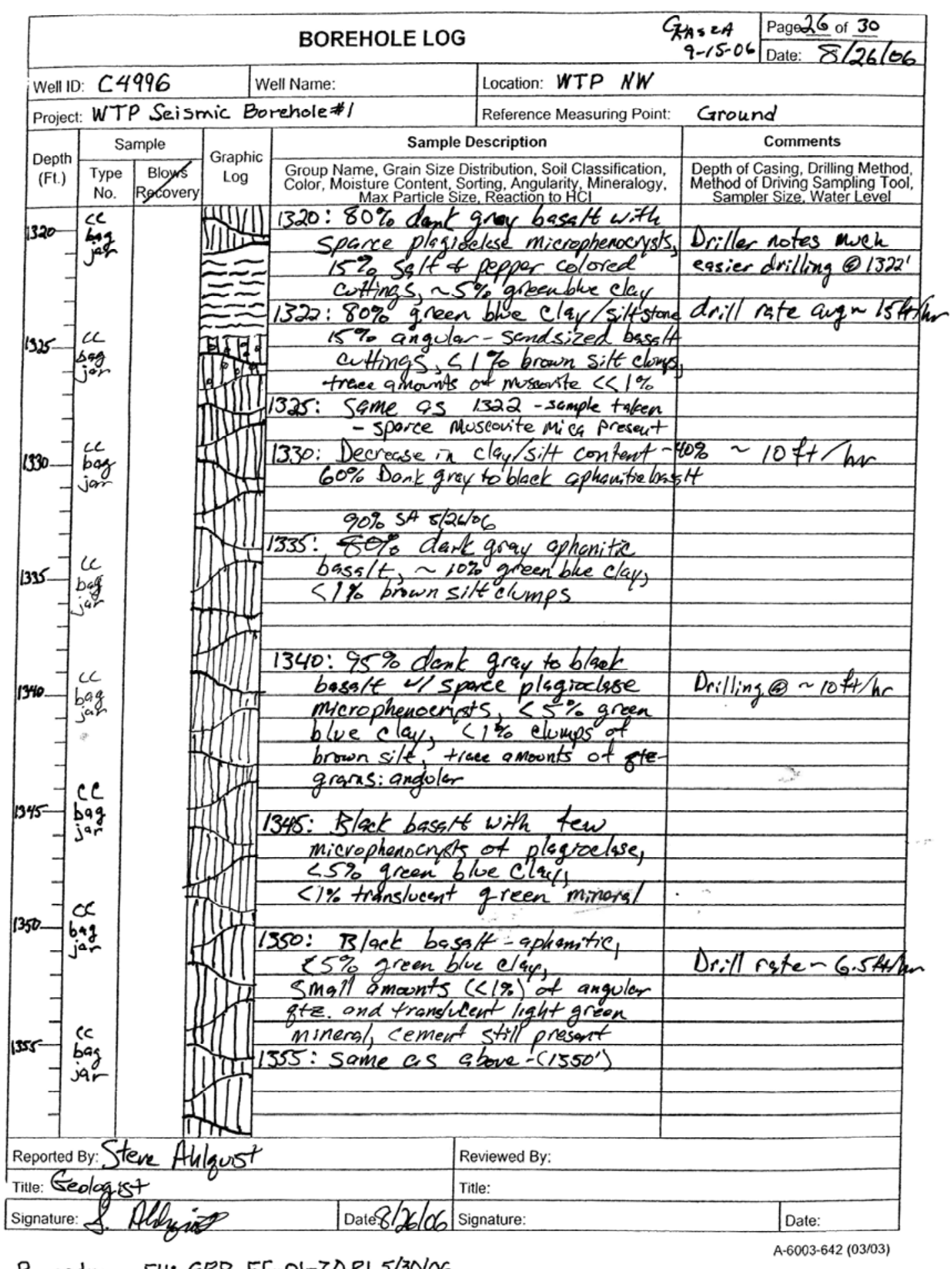

Procedure- FH; GRP-EE-OI-T.ORI 5/30/06

it th. A d it tional Sumbols used in the Graphic Log are documented in Appendix of PNNL-15848, R: 
WMP-32076 Rev. 0

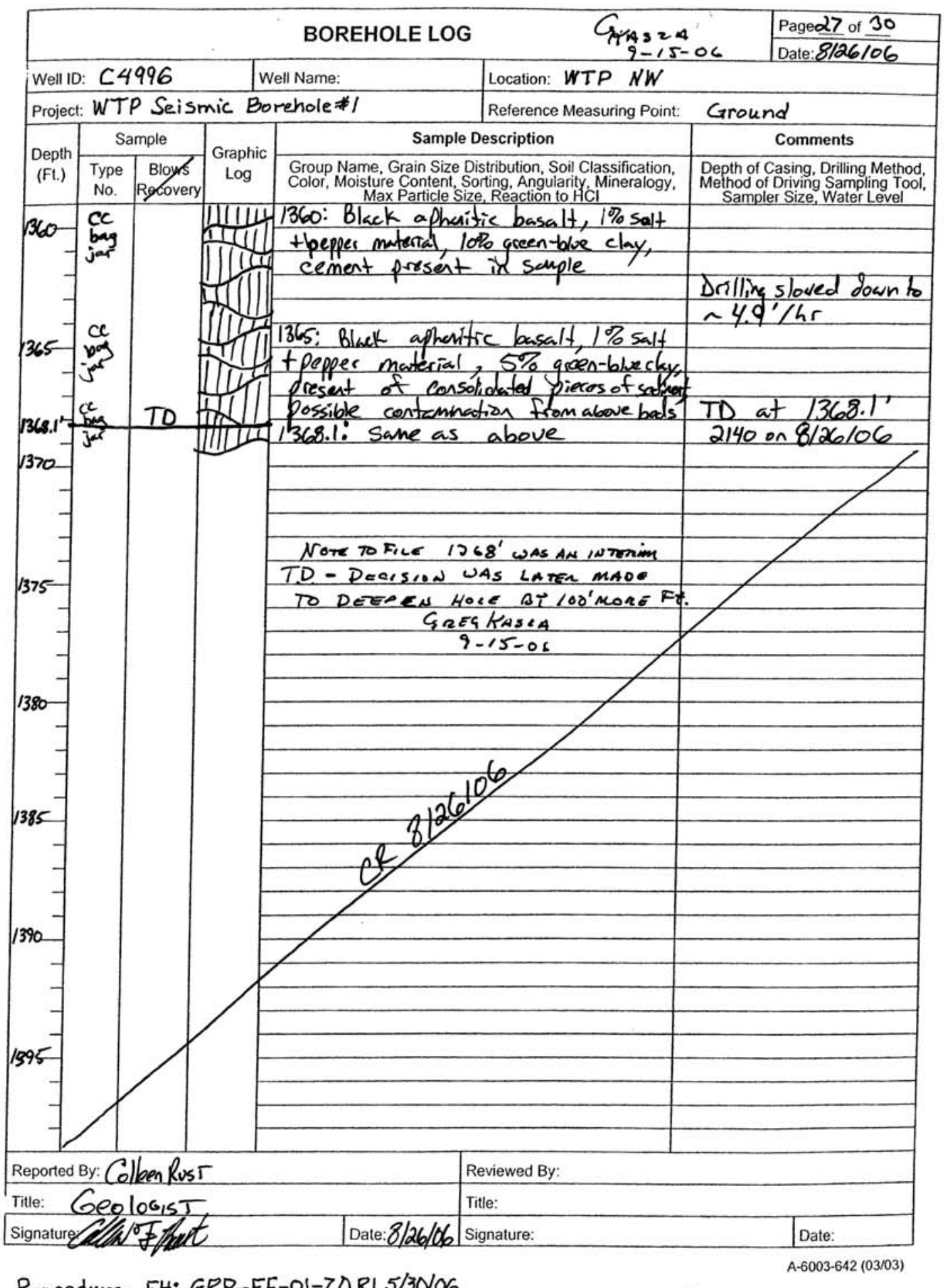

Procedure - FH; GRP-EE-OI-7.0,RI 5/30/06

A-6003-642 (03/03)

......tiansi Sirmbols used in the Graphic Log are documented in Appendix of PNNL-15848, R. 
WMP-32076 Rev. 0

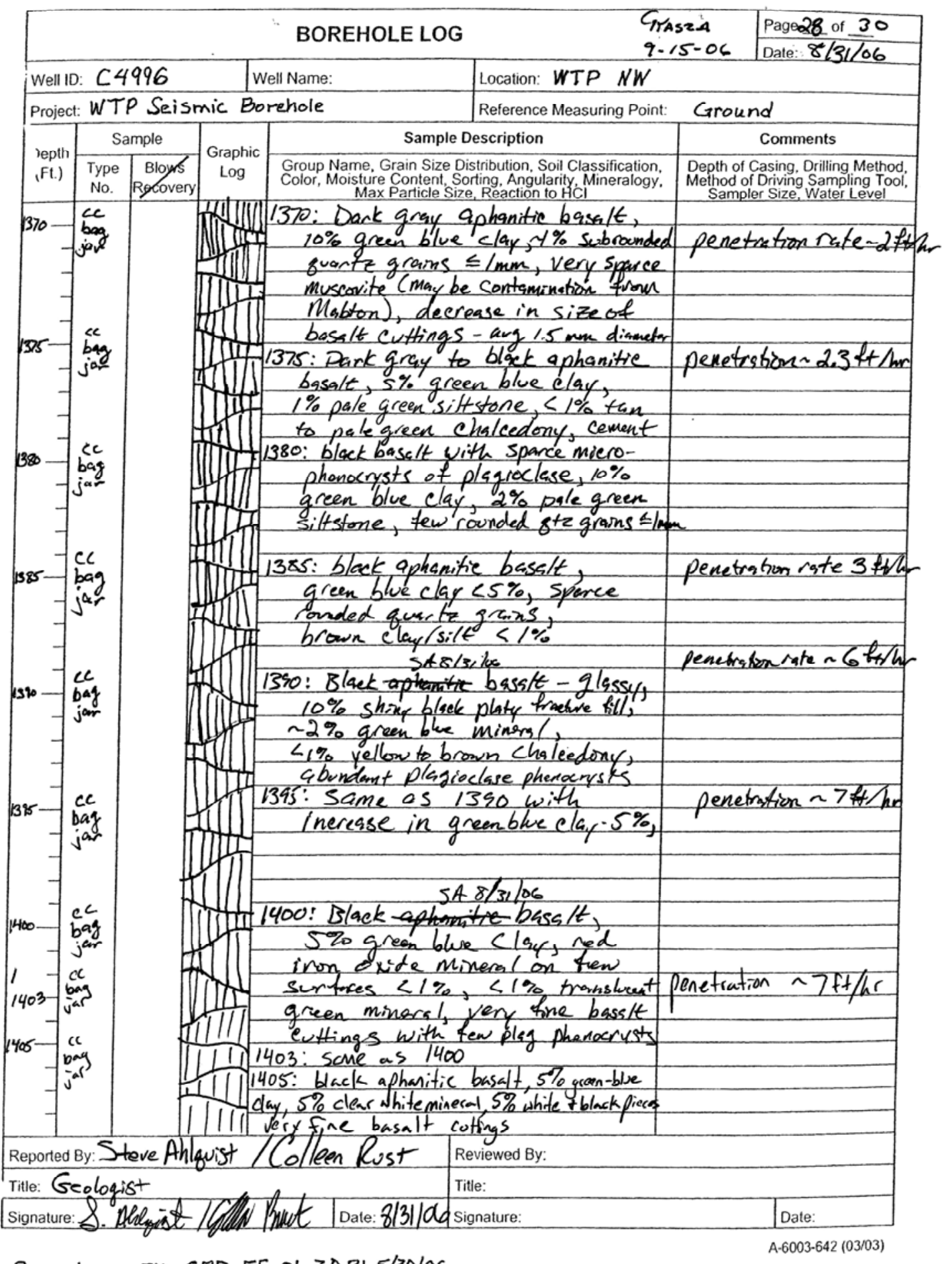

Procedure- FH; GRP-EE-0I-7.0,RI 5/30/06

.1. 11.t:innal Sumbols used in the Graphic Log are documented in Appendix of PNNL-15848, R2 
WMP-32076 Rev. 0

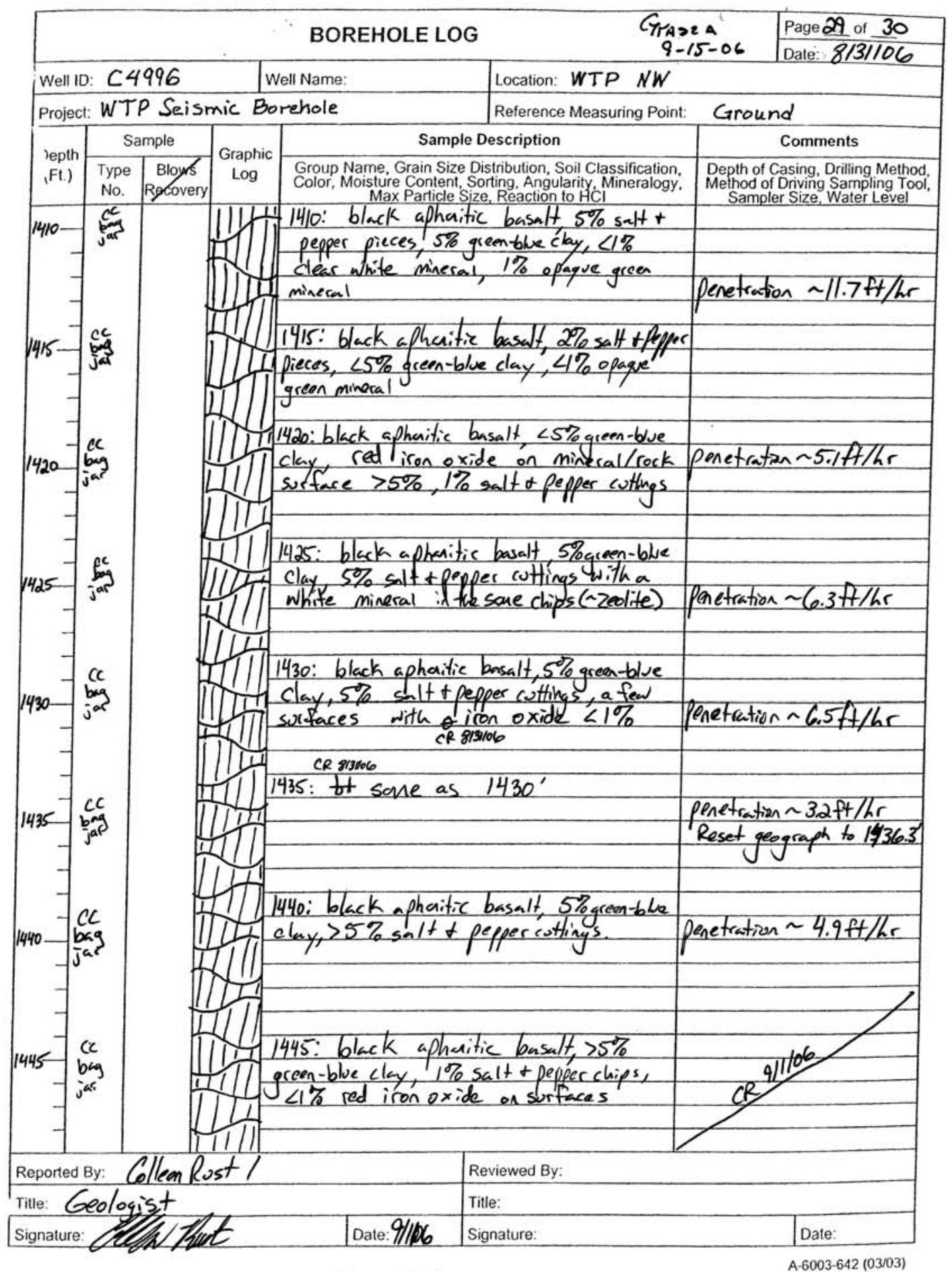

Procedure-FH; GRP-EE-OI-7.0,RI 5/30/06

it L. Adxtisnal Sumbols used in the Graphic Log are documented in Appendix of PNNL-15848, R.2 
WMP-32076 Rev. 0

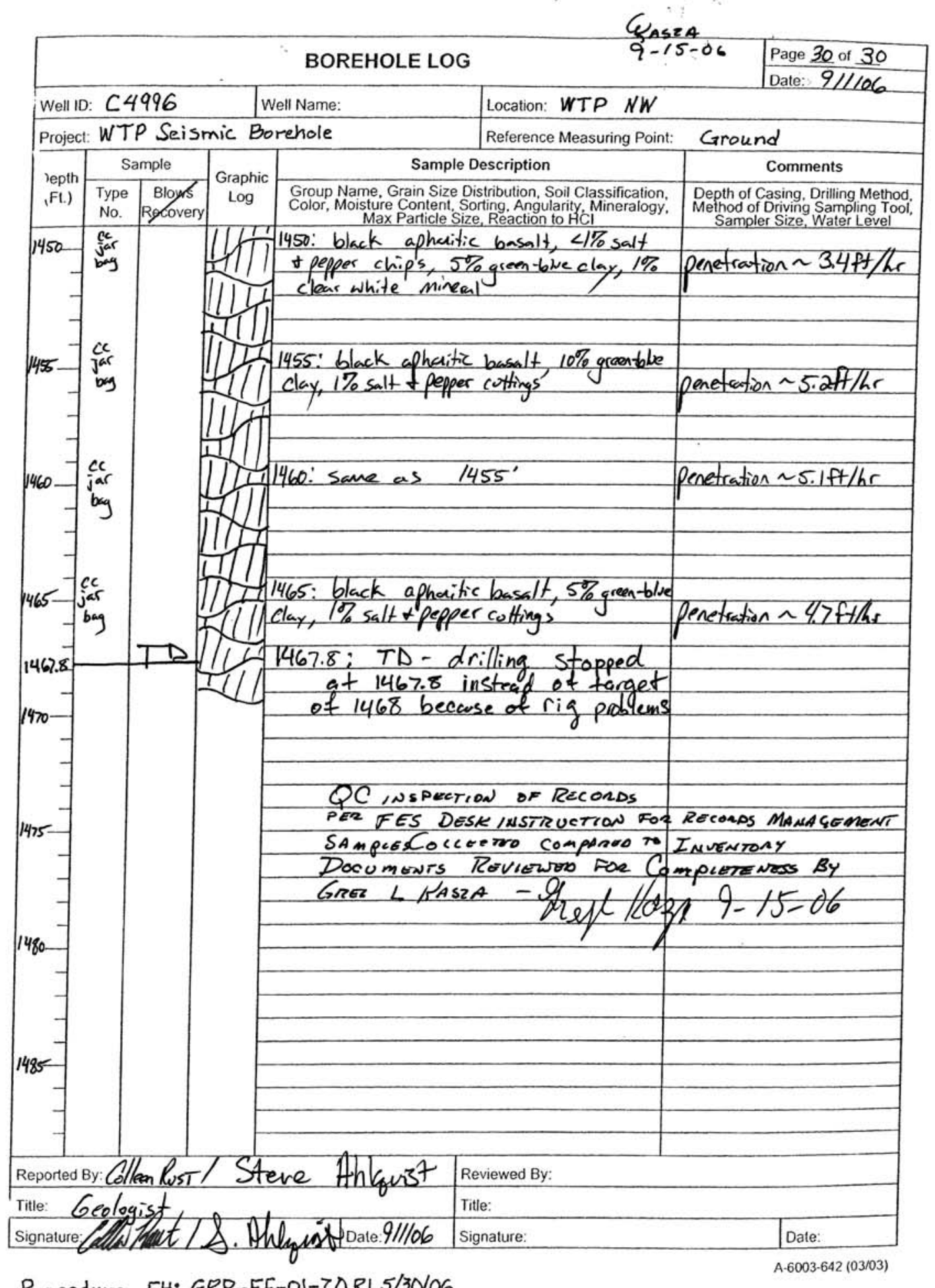

Procedure - FH; GRP-EE-OI-7.0,RI 5/30/06

A-6003-642 (03/03) 
WMP-32076 Rev. 0

\section{APPENDIX B}

BOREHOLE C4996 SAMPLE INVENTORY 
WMP-32076 Rev. 0

This page intentionally left blank

B- ii 


\title{
WASTE TREATMENT PLANT C4996 SAMPLE INVENTORY
}

\author{
A.) Sample Type Symbols: \\ $\checkmark$ Sample collected and verified \\ X No sample collected
}

1. Questionable slurry sample. Sample may not be representative of formation as the sand pump was not run continuously.

B.) There were numerous geolograph malfunctions during drilling which were identified and corrected within a short depth interval. Some individual samples may have been collected with minor (1-3') depth errors. Special attention was given to monitoring paper read outs and digital read outs to check for the introduction of footage errors. Most errors were introduced when lifting the drill string, particularly when adding pipe.

C.) No depth corrections were added for sample return time lag.

\begin{tabular}{|c|c|c|c|c|}
\hline \multirow{2}{*}{$\begin{array}{c}\text { BOTTOM } \\
\text { DEPTH } \\
\text { (FEET) }\end{array}$} & \multicolumn{3}{|c|}{ SAMPLE TYPE } & \multirow[t]{2}{*}{ NOTES } \\
\hline & JAR & CHIP & BAG & \\
\hline \multicolumn{5}{|c|}{ Elephant Mountain Member Basalt } \\
\hline 360 & $\mathrm{X}$ & $\checkmark$ & $\checkmark$ & Grout fill in entry hole casing \\
\hline 364.5 & $\mathrm{X}$ & $\checkmark \checkmark$ & $\checkmark$ & $\begin{array}{l}\text { First basalt chips in grout; top of Elephant } \\
\text { Mountain Basalt in rotary hole }\end{array}$ \\
\hline 367 & $\mathrm{X}$ & $\checkmark$ & $\mathrm{X}$ & \\
\hline 370 & $\mathrm{X}$ & $\checkmark$ & $\checkmark$ & \\
\hline 375 & $\mathrm{X}$ & $\checkmark$ & $\checkmark$ & \\
\hline 380 & $\mathrm{X}$ & $\checkmark$ & $\checkmark$ & \\
\hline 385 & $\mathrm{X}$ & $\checkmark$ & $\checkmark$ & \\
\hline 390 & $\mathrm{X}$ & $\checkmark$ & $\checkmark$ & \\
\hline 395 & $\mathrm{X}$ & $\checkmark$ & $\checkmark$ & \\
\hline 400 & $\mathrm{X}$ & $\checkmark$ & $\checkmark$ & \\
\hline 405 & $\mathrm{X}$ & $\checkmark$ & $\checkmark$ & \\
\hline 410 & $\mathrm{X}$ & $\checkmark$ & $\checkmark$ & \\
\hline 415 & $\mathrm{X}$ & $\checkmark$ & $\checkmark$ & \\
\hline 420 & $\mathrm{X}$ & $\checkmark$ & $\checkmark$ & Question mark on bag \\
\hline 425 & $\mathrm{X}$ & $\checkmark$ & $\checkmark$ & \\
\hline 430 & $\checkmark$ & $\checkmark$ & $\checkmark$ & Received direction to collect jar samples also \\
\hline 435 & $\checkmark$ & $\checkmark$ & $\checkmark$ & \\
\hline 440 & $\checkmark$ & $\checkmark$ & $\checkmark$ & \\
\hline 445 & $\checkmark$ & $\checkmark$ & $\checkmark$ & \\
\hline
\end{tabular}


WMP-32076 Rev. 0

\begin{tabular}{|c|c|c|c|c|}
\hline \multicolumn{5}{|c|}{ Rattlesnake Ridge Interbed } \\
\hline 450 & $\checkmark$ & $\checkmark$ & $\checkmark$ & $\begin{array}{l}\text { 447’ contact, top of Rattlesnake Ridge Interbed; } \\
\text { color shift to brown@447; Full shift to brown; } \\
\text { at 450'; First occurrence of clay balls at 452'. }\end{array}$ \\
\hline 455 & $\checkmark$ & $\checkmark$ & $\checkmark$ & \\
\hline 460 & $\checkmark$ & $\checkmark$ & $\checkmark$ & \\
\hline 465 & $\checkmark$ & $\checkmark$ & $\checkmark$ & Poor returns \\
\hline 470 & $\checkmark$ & $\mathrm{X}$ & $\checkmark$ & 1; Poor sample; some mud loss \\
\hline 475 & $\checkmark$ & $\checkmark$ & $\checkmark$ & $\begin{array}{l}\text { 1. No chip returns, only slurry sand. } \\
\text { Possible flowing sand }\end{array}$ \\
\hline 480 & $\checkmark$ & $\checkmark$ & $\checkmark$ & 1; No chip returns; unconsolidated sand \\
\hline 485 & $\checkmark$ & $\checkmark$ & $\checkmark$ & 1; No chip returns; unconsolidated sand \\
\hline 490 & $\checkmark$ & $\checkmark$ & $\mathrm{X}$ & 1; unconsolidated sand \\
\hline $492-493$ & $\checkmark$ & $\mathrm{X}$ & $\mathrm{X}$ & 1; Red color change \\
\hline 495 & $\checkmark$ & $\checkmark$ & $\begin{array}{c}\checkmark \checkmark \\
\text { Washed, } \\
\text { unwashed }\end{array}$ & $\begin{array}{l}\text { 1; unconsolidated sand; drillers noted about } \\
1,000-1,400 \text { gal. mud loss in the interbed. }\end{array}$ \\
\hline
\end{tabular}

B- 2 
WMP-32076 Rev. 0

\begin{tabular}{|c|c|c|c|c|}
\hline \multicolumn{5}{|c|}{ Pomona Member Basalt } \\
\hline 500 & $\checkmark$ & $\checkmark$ & $\checkmark$ & 495' top of Pomona Basalt \\
\hline 505 & $\checkmark$ & $\checkmark$ & $\checkmark$ & \\
\hline 510 & $\mathrm{X}$ & $\checkmark$ & $\checkmark$ & \\
\hline 515 & $\mathrm{X}$ & $\checkmark$ & $\checkmark$ & \\
\hline 520 & $\checkmark$ & $\checkmark$ & $\checkmark$ & \\
\hline 525 & $\mathrm{X}$ & $\checkmark$ & $\checkmark$ & \\
\hline 530 & $\mathrm{X}$ & $\checkmark$ & $\checkmark$ & \\
\hline 535 & $\mathrm{X}$ & $\mathrm{X}$ & $\checkmark$ & Fluid loss zone \\
\hline 539 & $\mathrm{X}$ & $\checkmark$ & $\mathrm{X}$ & \\
\hline 540 & $\mathrm{X}$ & $\checkmark$ & $\mathrm{X}$ & \\
\hline 545 & $\mathrm{X}$ & $\checkmark$ & $\checkmark$ & \\
\hline 550 & $\mathrm{X}$ & $\checkmark$ & $\checkmark$ & Note: unreliable sample; sand tank was cleaned. \\
\hline 555 & $\mathrm{X}$ & $\checkmark$ & $\checkmark$ & \\
\hline 560 & $\mathrm{X}$ & $\checkmark$ & $\checkmark$ & \\
\hline 565 & $\mathrm{X}$ & $\checkmark$ & $\mathrm{X}$ & \\
\hline 570 & $\mathrm{X}$ & $\checkmark$ & $\checkmark$ & \\
\hline 575 & $\checkmark$ & $\checkmark$ & $\checkmark$ & \\
\hline 580 & $\checkmark$ & $\checkmark$ & $\checkmark$ & \\
\hline 585 & $\checkmark$ & $\checkmark$ & $\checkmark$ & \\
\hline 590 & $\checkmark$ & $\checkmark$ & $\checkmark$ & \\
\hline 595 & $\mathrm{X}$ & $\checkmark$ & $\mathrm{X}$ & \\
\hline 600 & $\mathrm{X}$ & $\checkmark$ & $\checkmark$ & \\
\hline 605 & $\mathrm{X}$ & $\checkmark$ & $\checkmark$ & \\
\hline 610 & $\checkmark$ & $\checkmark$ & $\checkmark$ & \\
\hline 615 & $\checkmark$ & $\checkmark$ & $\checkmark$ & \\
\hline 620 & $\checkmark$ & $\checkmark$ & $\checkmark$ & Collected at 620.3', as composite for 5' \\
\hline 625 & $\checkmark$ & $\checkmark$ & $\checkmark$ & \\
\hline 630 & $\checkmark$ & $\checkmark$ & $\checkmark$ & Some grout in cuttings from cleaning chip tank. \\
\hline 635 & $\mathrm{X}$ & $\checkmark$ & $\checkmark$ & \\
\hline 640 & $\checkmark$ & $\checkmark$ & $\checkmark$ & \\
\hline 645 & $\checkmark$ & $\checkmark$ & $\checkmark$ & \\
\hline 650 & $\checkmark$ & $\checkmark$ & $\checkmark$ & \\
\hline 651 & $\checkmark$ & $\mathrm{X}$ & $\mathrm{X}$ & \\
\hline 655 & $\checkmark$ & $\checkmark$ & $\checkmark$ & \\
\hline 660 & $\checkmark$ & $\checkmark$ & $\checkmark$ & \\
\hline 665 & $\checkmark$ & $\checkmark$ & $\checkmark$ & \\
\hline 670 & $\checkmark$ & $\checkmark$ & $\checkmark$ & \\
\hline 675 & $\checkmark$ & $\checkmark$ & $\checkmark$ & \\
\hline 680 & $\checkmark$ & $\checkmark$ & $\checkmark$ & \\
\hline 681.5 & $\checkmark$ & $\checkmark$ & $\checkmark$ & Not shown on log \\
\hline 685 & $\checkmark$ & $X$ & $\checkmark$ & \\
\hline 690 & $\checkmark$ & $\checkmark$ & $\checkmark$ & \\
\hline 695 & $\checkmark$ & $\checkmark$ & $\checkmark$ & \\
\hline 698 & $\checkmark$ & $\checkmark$ & $\checkmark$ & \\
\hline
\end{tabular}

B- 3 
WMP-32076 Rev. 0

\begin{tabular}{|l|l|l|l|l|}
\hline Selah Interbed & $\checkmark$ & $\checkmark$ & X & Contact 699.5- Selah Interbed \\
\hline 699.5 & $\checkmark$ & $X$ & $X$ & $\begin{array}{l}\text { Mainly clay. Sample impacted by raising pipe } \\
\text { and circulating }\end{array}$ \\
\hline 701.2 & $\checkmark$ & $\mathrm{X}$ & $\mathrm{X}$ & $\cdot$ \\
\hline 701.7 & $\checkmark$ & $\mathrm{X}$ & $\mathrm{X}$ & No chips returned. \\
\hline 705 & $\mathrm{X}$ & $\checkmark$ & $\mathrm{X}$ & \\
\hline 708.4 & $\checkmark$ & $\mathrm{X}$ & $\mathrm{X}$ & No chips returned. \\
\hline 710 & $\mathrm{X}$ & $\checkmark$ & $\mathrm{X}$ & \\
\hline 711.8 & $\mathrm{X}$ & $\mathrm{X}$ & $\mathrm{X}$ & \\
\hline 715 & $\mathrm{X}$ & $\checkmark$ & $\mathrm{X}$ & Grab sample \\
\hline 716.9 & $\checkmark$ & $\mathrm{X}$ & $\mathrm{X}$ & Grab sample \\
\hline 718.6 & $\checkmark$ & $\checkmark$ & $\mathrm{X}$ & \\
\hline 720 & & & & \\
\hline
\end{tabular}

\begin{tabular}{|l|c|c|c|l|}
\hline \multicolumn{6}{|l}{ Esquatzel Member Basalt } & \multicolumn{4}{l|}{} \\
\hline 725 & $\mathrm{X}$ & $\mathrm{X}$ & $\mathrm{X}$ & Contact- Esquatel Basalt 720' \\
\hline 728 & $\checkmark$ & $\checkmark$ & $\checkmark$ & \\
\hline 730 & $\checkmark$ & $\checkmark$ & $\checkmark$ & \\
\hline 735 & $\checkmark$ & $\checkmark$ & $\checkmark$ & \\
\hline 740 & $\checkmark$ & $\checkmark$ & $\checkmark$ & \\
\hline 745 & $\checkmark$ & $\checkmark$ & $\checkmark$ & \\
\hline 750 & $\checkmark$ & $\checkmark$ & $\checkmark$ & \\
\hline 755 & $\checkmark$ & $\checkmark$ & $\checkmark$ & \\
\hline 760 & $\checkmark$ & $\checkmark$ & $\checkmark$ & \\
\hline 765 & $\checkmark$ & $\checkmark$ & $\checkmark$ & \\
\hline 770 & $\checkmark$ & $\checkmark$ & $\checkmark$ & \\
\hline 775 & $\checkmark$ & $\checkmark$ & $\checkmark$ & \\
\hline 780 & $\checkmark$ & $\checkmark$ & $\checkmark$ & \\
\hline 785 & $\checkmark$ & $\checkmark$ & $\checkmark$ & \\
\hline 790 & $\checkmark$ & $\checkmark$ & $\checkmark$ & \\
\hline 795 & $\checkmark$ & $\checkmark$ & $\checkmark$ & \\
\hline 800 & $\checkmark$ & $\checkmark$ & $\checkmark$ & Poor return on cuttings; sticks and leaves noted. \\
\hline 805 & $\checkmark$ & $\checkmark$ & $\checkmark$ & \\
\hline 810 & $\checkmark$ & $\checkmark$ & $\checkmark$ & \\
\hline
\end{tabular}


WMP-32076 Rev. 0

\begin{tabular}{|c|c|c|c|c|}
\hline \multicolumn{5}{|c|}{ Cold Creek Interbed } \\
\hline 815 & $\checkmark$ & $\checkmark$ & $\checkmark$ & $\begin{array}{l}\text { 1; Contact Cold Creek Interbed 814.5’; poor } \\
\text { sample returns; siltstones 814.5-830’ }\end{array}$ \\
\hline 820 & $\checkmark$ & $\checkmark$ & $\mathrm{X}$ & 1 ; Not enough sample return for bag \\
\hline 825 & $\checkmark$ & $\checkmark$ & $\checkmark$ & 1. \\
\hline 830 & $\checkmark$ & $\checkmark$ & $\checkmark$ & $\begin{array}{l}1 \text {; poor sample returns; unconsolidated sands } \\
\text { below } 830 \text { ' }\end{array}$ \\
\hline 835 & $\checkmark$ & $\checkmark$ & $\mathrm{X}$ & 1 ; poor sample returns \\
\hline 840 & $\checkmark$ & $\checkmark$ & $\mathrm{X}$ & 1; poor sample returns \\
\hline 845 & $\checkmark$ & $\checkmark$ & $\mathrm{X}$ & 1; poor sample returns \\
\hline 850 & $\checkmark$ & $\checkmark$ & $\mathrm{X}$ & 1; poor sample returns \\
\hline 855 & $\checkmark$ & $\checkmark$ & $\mathrm{X}$ & 1; poor sample returns \\
\hline 860 & $\checkmark$ & $\checkmark$ & $\mathrm{X}$ & 1; poor sample returns; mud changed \\
\hline 865 & $\checkmark$ & $\checkmark$ & $\mathrm{X}$ & 1; poor sample returns \\
\hline 870 & $\checkmark$ & $\checkmark$ & $\mathrm{X}$ & 1; poor sample returns \\
\hline 873 & $\checkmark$ & $\mathrm{X}$ & $\mathrm{X}$ & 1, clay \\
\hline 875 & $\checkmark$ & $\checkmark$ & $\mathrm{X}$ & 1 , clay on screen \\
\hline 879 & $\checkmark$ & $X$ & $\mathrm{X}$ & 1. \\
\hline 880 & $\checkmark$ & $\checkmark$ & $\mathrm{X}$ & 1. \\
\hline 885 & $\checkmark$ & $\checkmark$ & $\mathrm{X}$ & 1 , clay on screen \\
\hline 888 & $\checkmark$ & $\mathrm{X}$ & $\mathrm{X}$ & 1. \\
\hline 890 & $\checkmark$ & $\checkmark$ & $\mathrm{X}$ & 1. \\
\hline 895 & $\checkmark$ & $\checkmark$ & $\mathrm{X}$ & 1; poor sample returns \\
\hline 900 & $\checkmark$ & $\checkmark$ & $\mathrm{X}$ & 1. \\
\hline 905 & $\checkmark$ & $\checkmark$ & $\mathrm{X}$ & 1. \\
\hline 910 & $\checkmark$ & $\checkmark$ & $\mathrm{X}$ & 1. \\
\hline
\end{tabular}

B- 5 
WMP-32076 Rev. 0

\begin{tabular}{|c|c|c|c|c|}
\hline \multicolumn{5}{|c|}{ Umatilla Member Basalt } \\
\hline 915 & $\checkmark$ & $\checkmark$ & $\checkmark$ & Contact 910.8’ Top of Umatilla Basalt \\
\hline 920 & $\checkmark$ & $\checkmark$ & $\checkmark$ & \\
\hline 925 & $\checkmark$ & $\checkmark$ & $\checkmark$ & \\
\hline 930 & $\checkmark$ & $\checkmark$ & $\checkmark$ & \\
\hline 935 & $\checkmark$ & $\checkmark$ & $\checkmark$ & \\
\hline 940 & $\checkmark$ & $\checkmark$ & $\checkmark$ & \\
\hline 945 & $\checkmark$ & $\checkmark$ & $\checkmark$ & $\begin{array}{l}\text { NEW BIT INSTALLED. The previous bit had } \\
\text { hemispherical buttons and was replaced with a } \\
\text { new, pointed-button bit. Downward, the chip } \\
\text { size is approximately halved to quartered and } \\
\text { the chip shape changes from a flat to curved } \\
\text { flake to an equate particle, approximately } \\
\text { coarse sand sized. Significant portions washed } \\
\text { through the screen. } \\
\text { Note: Upward red paint was frequently seen in } \\
\text { the chips. Downward, the fresh paint on the } \\
\text { new bit was dark metallic green and not as } \\
\text { easily noted. }\end{array}$ \\
\hline 950 & $\checkmark$ & $\checkmark$ & $\checkmark$ & Apparent cement fall in \\
\hline 955 & $\checkmark$ & $\checkmark$ & $\checkmark$ & Questionable quality \\
\hline 960 & $\checkmark$ & $\checkmark$ & $\checkmark$ & $\begin{array}{l}\text { Mud change- lightened; fines are falling out of } \\
\text { mud. }\end{array}$ \\
\hline 965 & $\checkmark$ & $\checkmark$ & $\checkmark$ & $\begin{array}{l}\text { Red cloth fibers from rag in pump start here and } \\
\text { continue downward }\end{array}$ \\
\hline 970 & $\checkmark$ & $\checkmark$ & $\checkmark$ & \\
\hline 975 & $\checkmark$ & $\checkmark$ & $\checkmark$ & \\
\hline 980 & $\checkmark$ & $\checkmark$ & $\checkmark$ & \\
\hline 985 & $\checkmark$ & $\checkmark$ & $\checkmark$ & \\
\hline 990 & $\checkmark$ & $\checkmark$ & $\checkmark$ & Approximate 3' depth correction \\
\hline 995 & $\checkmark$ & $\checkmark$ & $\mathrm{X}$ & \\
\hline 1000 & $\checkmark$ & $\checkmark$ & $\checkmark$ & \\
\hline 1005 & $\checkmark$ & $\checkmark$ & $\checkmark$ & \\
\hline 1010 & $\checkmark$ & $\checkmark$ & $\checkmark$ & \\
\hline 1015 & $\checkmark$ & $\checkmark$ & $\checkmark$ & \\
\hline 1020 & $\checkmark$ & $\checkmark$ & $\checkmark$ & \\
\hline 1025 & $\checkmark$ & $\checkmark$ & $\checkmark$ & \\
\hline 1030 & $\checkmark$ & $\checkmark$ & $\checkmark$ & $\begin{array}{l}\text { First occurrence of pyrite framboids, continuing } \\
\text { at least down to } 1053 \text { '. }\end{array}$ \\
\hline 1035 & $\checkmark$ & $\checkmark$ & $\checkmark$ & \\
\hline 1040 & $\checkmark$ & $\checkmark$ & $\checkmark$ & \\
\hline 1045 & $\checkmark$ & $\checkmark$ & $\checkmark$ & \\
\hline 1050 & $\checkmark$ & $\checkmark$ & $\checkmark$ & \\
\hline 1055 & $\checkmark$ & $\checkmark$ & $\checkmark$ & \\
\hline 1060 & $\checkmark$ & $\checkmark$ & $\checkmark$ & \\
\hline 1065 & $\checkmark$ & $\checkmark$ & $\checkmark$ & Slight color change \\
\hline
\end{tabular}


WMP-32076 Rev. 0

\begin{tabular}{|c|c|c|c|c|}
\hline \multicolumn{5}{|c|}{ Mabton Interbed } \\
\hline 1070 & $\checkmark$ & $\checkmark$ & $\mathrm{X}$ & $\begin{array}{l}\text { Contact 1066.8' Top of Mabton Interbed; water } \\
\text { loss zone. }\end{array}$ \\
\hline 1075 & $\checkmark$ & $\checkmark$ & $\checkmark$ & Poor sample returns \\
\hline 1080 & $\checkmark$ & $\checkmark$ & $\checkmark$ & \\
\hline 1085 & $\checkmark$ & $\checkmark$ & $\checkmark$ & \\
\hline 1090 & $\checkmark$ & $\checkmark$ & $\checkmark$ & \\
\hline 1095 & $\checkmark$ & $\checkmark$ & $\checkmark$ & Circulation problems at 1093' \\
\hline 1100 & $\checkmark$ & $\checkmark$ & $\checkmark$ & \\
\hline 1105 & $\checkmark$ & $\checkmark$ & $\checkmark$ & \\
\hline 1110 & $\checkmark$ & $\checkmark$ & $\checkmark$ & \\
\hline 1113 & $\checkmark$ & $\checkmark$ & $\checkmark$ & Thinned mud \\
\hline 1115 & $\mathrm{X}$ & $\mathrm{X}$ & $\mathrm{X}$ & \\
\hline 1120 & $\mathrm{X}$ & $\mathrm{X}$ & $\mathrm{X}$ & $\begin{array}{l}\text { No sample taken because of identified depth } \\
\text { error on geolograph. Was reset for the correct } \\
1125 \text { ' sample. }\end{array}$ \\
\hline 1125 & $\checkmark$ & $\checkmark$ & $\checkmark$ & \\
\hline 1130 & $\checkmark$ & $\checkmark$ & $\checkmark$ & \\
\hline 1135 & $\mathrm{X}$ & $\mathrm{X}$ & $\mathrm{X}$ & Poor returns \\
\hline 1140 & $\checkmark$ & $\checkmark$ & $\checkmark$ & \\
\hline 1145 & $\checkmark$ & $\checkmark$ & $\checkmark$ & $\begin{array}{l}\text { Potential mud and circulation problems noted } \\
\text { approximately at this depth. }\end{array}$ \\
\hline 1150 & $\checkmark$ & $\checkmark$ & $\checkmark$ & Sampled from surface casing \\
\hline 1155 & $\checkmark$ & $\checkmark$ & $\checkmark$ & Poor returns \\
\hline 1160 & $\checkmark$ & $\checkmark$ & $\checkmark$ & \\
\hline 1165 & $\checkmark$ & $\mathrm{X}$ & $\mathrm{X}$ & \\
\hline
\end{tabular}


WMP-32076 Rev. 0

\begin{tabular}{|c|c|c|c|c|}
\hline \multicolumn{5}{|c|}{ Priest Rapids Member Basalt } \\
\hline 1168 & $\checkmark$ & $\checkmark$ & $\checkmark$ & $\begin{array}{l}\text { Basalt contact, top of Priest Rapids Basalt, } \\
\text { 1168' }\end{array}$ \\
\hline 1170 & $\checkmark$ & $\checkmark \checkmark$ & $\mathrm{X}$ & \\
\hline 1175 & $\checkmark$ & $\checkmark$ & $\mathrm{X}$ & $\begin{array}{l}\text { Drilling mud disturbance at } 1168-1170.3^{\prime} ; \\
\text { Depth correction on sample of } 1174 \text { ' rather than } \\
1185.3^{\prime}\end{array}$ \\
\hline 1180 & $\checkmark$ & $\checkmark$ & $\mathrm{X}$ & \\
\hline 1181 & $\mathrm{X}$ & $\mathrm{X}$ & $\checkmark$ & $\begin{array}{l}\text { Geolograph depth error noted- } 12 \text { '; may be } \\
1170^{\prime} \text { or } 1169 \text { '. }\end{array}$ \\
\hline 1185 & $\checkmark$ & $\checkmark$ & $\checkmark$ & \\
\hline 1190 & $\checkmark$ & $\checkmark$ & $\mathrm{X}$ & \\
\hline 1195 & $\checkmark$ & $\checkmark$ & $\checkmark$ & $\begin{array}{l}\text { Potential geolograph errors repeating. } \\
\text { Circulation problems. }\end{array}$ \\
\hline 1198 & $\checkmark$ & $\checkmark$ & $\checkmark$ & Stopped for cement \& recirculation \\
\hline 1200 & $\checkmark$ & $\checkmark$ & $\checkmark$ & \\
\hline 1205 & $\checkmark$ & $\checkmark$ & $\checkmark$ & \\
\hline 1210 & $\checkmark$ & $\checkmark$ & $\checkmark$ & \\
\hline 1215 & $\checkmark$ & $\checkmark$ & $\checkmark$ & \\
\hline 1220 & $\checkmark$ & $\checkmark$ & $\checkmark$ & \\
\hline 1225 & $\checkmark$ & $\checkmark$ & $\checkmark$ & \\
\hline 1230 & $\checkmark$ & $\checkmark$ & $\checkmark$ & \\
\hline 1235 & $\checkmark$ & $\checkmark$ & $\checkmark$ & \\
\hline 1240 & $\checkmark$ & $\checkmark$ & $\checkmark$ & \\
\hline 1245 & $\checkmark$ & $\checkmark$ & $\checkmark$ & \\
\hline 1250 & $\checkmark$ & $\checkmark$ & $\checkmark$ & \\
\hline 1255 & $\checkmark$ & $\checkmark$ & $\checkmark$ & \\
\hline 1260 & $\checkmark$ & $\checkmark$ & $\checkmark$ & \\
\hline 1265 & $\checkmark$ & $\checkmark$ & $\checkmark$ & \\
\hline 1270 & $\checkmark$ & $\checkmark$ & $\checkmark$ & \\
\hline 1275 & $\checkmark$ & $\checkmark$ & $\checkmark$ & \\
\hline 1280 & $\checkmark$ & $\checkmark$ & $\checkmark$ & \\
\hline 1285 & $\checkmark$ & $\checkmark$ & $\checkmark$ & \\
\hline 1290 & $\checkmark$ & $\checkmark$ & $\checkmark$ & \\
\hline 1295 & $\checkmark$ & $\checkmark$ & $\checkmark$ & \\
\hline 1300 & $\checkmark$ & $\checkmark$ & $\checkmark$ & \\
\hline 1305 & $\checkmark$ & $\checkmark$ & $\checkmark$ & \\
\hline 1310 & $\checkmark$ & $\checkmark$ & $\checkmark$ & \\
\hline 1315 & $\checkmark$ & $\checkmark$ & $\checkmark$ & \\
\hline 1320 & $\checkmark$ & $\checkmark$ & $\checkmark$ & \\
\hline 1322 & $\checkmark$ & $\checkmark$ & $\checkmark$ & Not on log \\
\hline 1325 & $\checkmark$ & $\checkmark$ & $\checkmark$ & \\
\hline 1330 & $\checkmark$ & $\checkmark$ & $\checkmark$ & Drilling rate $-10 \mathrm{f} / \mathrm{hr}$ \\
\hline 1335 & $\checkmark$ & $\checkmark$ & $\checkmark$ & \\
\hline 1340 & $\checkmark$ & $\checkmark$ & $\checkmark$ & \\
\hline 1345 & $\checkmark$ & $\checkmark$ & $\checkmark$ & \\
\hline 1350 & $\checkmark$ & $\checkmark$ & $\checkmark$ & \\
\hline
\end{tabular}

B- 8 
WMP-32076 Rev. 0

\begin{tabular}{|c|c|c|c|c|}
\hline 1355 & $\checkmark$ & $\checkmark$ & $\checkmark$ & \\
\hline 1360 & $\checkmark$ & $\checkmark$ & $\checkmark$ & \\
\hline 1365 & $\checkmark$ & $\checkmark$ & $\checkmark$ & \\
\hline 1368.1 & $\checkmark$ & $\checkmark$ & $\checkmark$ & Temporary Total Depth \\
\hline 1370 & $\checkmark$ & $\checkmark$ & $\checkmark$ & \\
\hline 1375 & $\checkmark$ & $\checkmark$ & $\checkmark$ & \\
\hline 1380 & $\checkmark$ & $\checkmark$ & $\checkmark$ & \\
\hline 1385 & $\checkmark$ & $\checkmark$ & $\checkmark$ & \\
\hline 1390 & $\checkmark$ & $\checkmark$ & $\checkmark$ & \\
\hline 1395 & $\checkmark$ & $\checkmark$ & $\checkmark$ & \\
\hline 1400 & $\checkmark$ & $\checkmark$ & $\checkmark$ & \\
\hline 1403 & $\checkmark$ & $\mathrm{X}$ & $\checkmark$ & Rosa Member contact $1400^{\prime}-1403^{\prime}$ range \\
\hline 1405 & $\checkmark$ & $\checkmark$ & $\checkmark$ & \\
\hline 1410 & $\checkmark$ & $\checkmark$ & $\checkmark$ & $\begin{array}{l}\text { Drilling rate of } 6.9 \mathrm{ft} / \mathrm{hr} \text { from } 1404.5^{\prime} \text { to } \\
1413.3^{\prime} \text {. }\end{array}$ \\
\hline 1415 & $\checkmark$ & $\checkmark$ & $\checkmark$ & $\begin{array}{l}\text { Drilling rate of } 11.7 \mathrm{ft} / \mathrm{hr} \text { from } 1413.3^{\prime} \text { to } \\
1417.6^{\prime} \text {. }\end{array}$ \\
\hline 1420 & $\checkmark$ & $\checkmark$ & $\checkmark$ & \\
\hline 1425 & $\checkmark$ & $\checkmark$ & $\checkmark$ & \\
\hline 1430 & $\checkmark$ & $\checkmark$ & $\checkmark$ & \\
\hline 1435 & $\checkmark$ & $\checkmark$ & $\checkmark$ & \\
\hline 1440 & $\checkmark$ & $\checkmark$ & $\checkmark$ & \\
\hline 1445 & $\checkmark$ & $\checkmark$ & $\checkmark$ & \\
\hline 1450 & $\checkmark$ & $\checkmark$ & $\checkmark$ & \\
\hline 1455 & $\checkmark$ & $\checkmark$ & $\checkmark$ & \\
\hline 1460 & $\checkmark$ & $\checkmark$ & $\checkmark$ & \\
\hline 1465 & $\checkmark$ & $\checkmark$ & $\checkmark$ & \\
\hline 1465.4 --TD-- & $\checkmark$ & $\mathrm{X}$ & $\mathrm{X}$ & Bottom of Hole \\
\hline
\end{tabular}

B- 9 
WMP-32076 Rev. 0

This page intentionally left blank

B- 10 
WMP-32076 Rev. 0

APPENDIX C

BOREHOLE C4996 LOG SUMMARY 
WMP-32076 Rev. 0

This page intentionally left blank 


\section{LOG SUMMARY FOR BOREHOLE C4996}

This summary describes the stratigraphic sequence underlying the initial basalt member. Overlying alluvial sediments (0-349’ bgs) are described in a separate report.

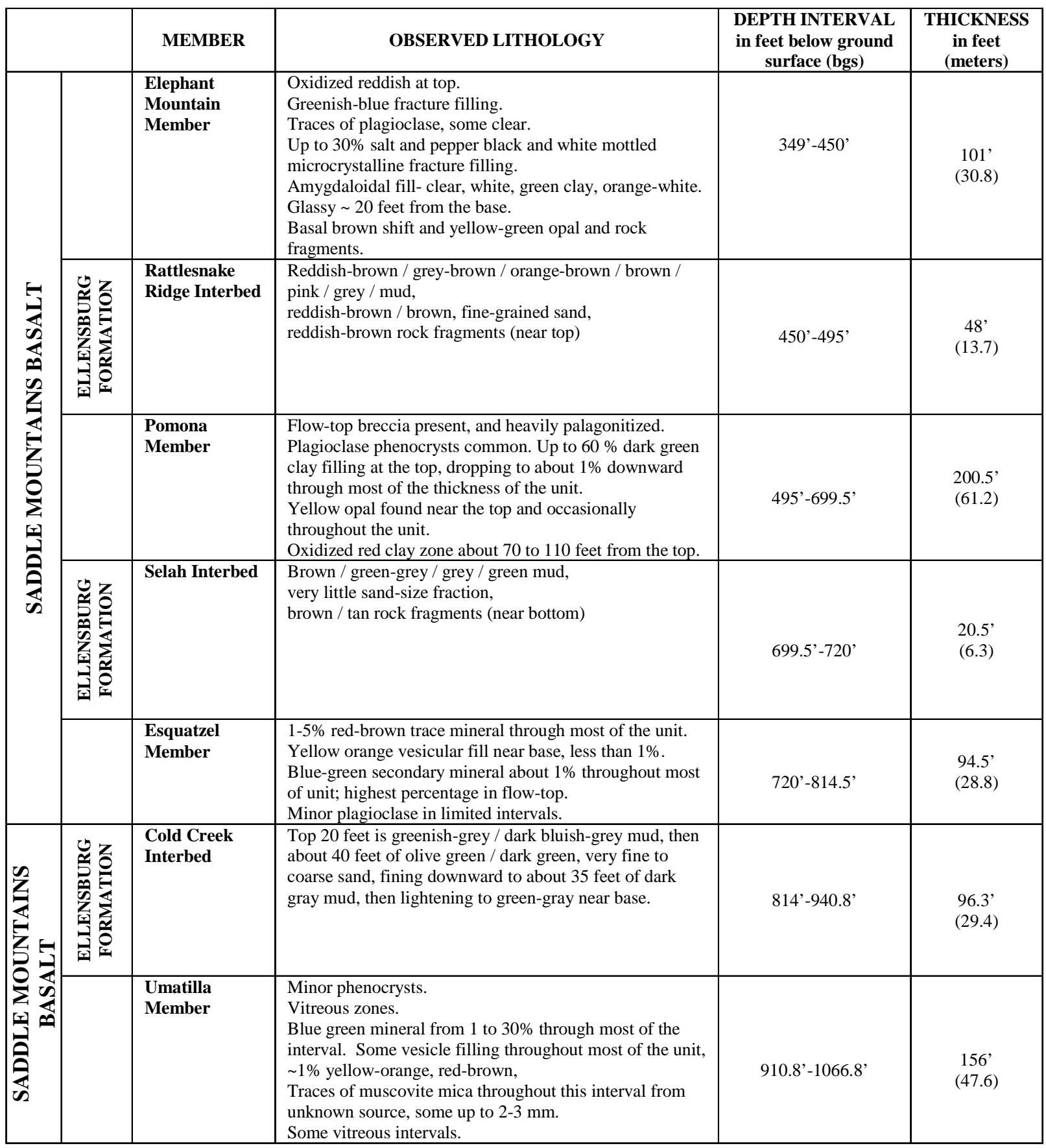


WMP-32076 Rev. 0

\begin{tabular}{|c|c|c|c|c|c|}
\hline & 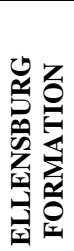 & $\begin{array}{l}\text { Mabton } \\
\text { Interbed }\end{array}$ & $\begin{array}{l}\text { Green / orange / dark greenish-grey mud in top 3-9 feet, } \\
\text { Possible gravel layer about } 50 \text { below top, } \\
\text { About } 80 \text { feet alternating, dark greenish-grey fine- to medium grained sand } \\
\text { and mud, upper } 40 \text { ' with returns to shaker, lower 40' with no returns to the } \\
\text { mud shaker. } \\
\text { About } 10 \text { feet of mixed clays and basalt at the base. } \\
\text { Some muscovite in lower sands. }\end{array}$ & $\begin{array}{l}\text { 1066.8'- } \\
1168\end{array}$ & $\begin{array}{l}101.2^{\prime} \\
(30.9)\end{array}$ \\
\hline \multirow{3}{*}{ 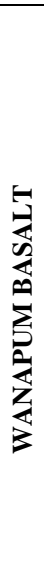 } & & $\begin{array}{l}\text { Priest Rapids } \\
\text { Member, } \\
\text { Lolo flow }\end{array}$ & $\begin{array}{l}\text { Little evidence of plagioclase phenocrysts. } \\
1-50 \% \text { blue green fracture fill through most of the unit. } \\
\text { Scattered microcrystalline white-black (salt and pepper) basalt vein filling. } \\
\text { Red-brown oxidized staining scattered through the unit. }\end{array}$ & $\begin{array}{l}\text { 1168'- } \\
1322^{\prime}\end{array}$ & $\begin{array}{l}154 \\
(47)\end{array}$ \\
\hline & 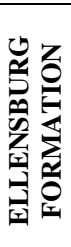 & $\begin{array}{l}\text { Unidentified } \\
\text { Interbed }\end{array}$ & $\begin{array}{l}\text { Greenish-blue mud, brown (mud?) rock fragments, muscovite mica at lower } \\
\text { contact. }\end{array}$ & $\begin{array}{c}1322^{\prime}- \\
1327^{\prime} \pm 2 ’\end{array}$ & $\begin{array}{l}5,+2 \\
(1.5 \\
+0.6)\end{array}$ \\
\hline & & $\begin{array}{l}\text { Priest Rapids } \\
\text { Member, } \\
\text { Rosalia flow }\end{array}$ & $\begin{array}{l}\text { Substantially reduced content of blue-green fracture fill clay }(0-10 \%) \text {. } \\
\text { Basalt, with micro phenocrysts starting at } 137 \text { ' below top of Rosalia flow and } \\
\text { extending to } 152 \text { ' below top. }\end{array}$ & $\begin{array}{l}1327^{\prime}+2^{\prime}- \\
\text { TD } \\
\left(1467.8^{\prime}\right)\end{array}$ & NA \\
\hline
\end{tabular}

(1) Note: Samples collected in the interbed sands and silts should be considered potentially non-representative of the unit since the vortex sand pump on the mud shaker was not continually in operation. Consequently, interbed slurry samples in archive jars may contain particles from outside the sampling interval. 
WMP-32076 Rev. 0

\section{APPENDIX D}

FREESTONE ENVIRONMENTAL SERVICES, INC.

PROJECT DESK INSTRUCTION 
WMP-32076 Rev. 0

This page intentionally left blank

D-ii 
WMP-32076 Rev. 0

FREESTONE ENVIRONMENTAL SERVICES, Inc.

\author{
DESK INSTRUCTION FOR RECORDS MANAGEMENT TO SUPPORT \\ WASTE TREATMENT PLANT - PNNL SEISMIC BOREHOLES PROJECT
}

$\begin{aligned} \text { Approved By: } & \text { Signature on file } \\ \text { Daniel K. Tyler, President } & \text { Date: } \\ \text { Freestone Environmental Services, Inc. } & \end{aligned}$

\title{
Reference Documents:
}

Pacific Northwest National Laboratory, PNNL-15848, Sampling and Analysis Plan Waste Treatment Plant Seismic Borehole Project, - (latest revision)

Fluor Hanford, Inc., GRP-EE-01-7.0, Groundwater Remediation Project Procedure, Geologic Logging, - (latest revision)

ASTM D5434-03, Standard Practice for Preserving and Transporting Rock Core Samples

Strategy:

1) Record generators (geologists) will complete records to implement PNNL, FH, and ASTM procedures and data fields, as appropriate.

2) The Freestone Environmental Quality Control Inspector will ensure completeness, consistency, and legibility.

3) Records generated will be "working, in-progress records," until approved by QC Inspector.

4) QC verified records will employ a multiple-location storage system with photo copied records being equivalent to original records. No records will be designated as originals.

5) Drill cuttings samples will be considered records.

Records Process for Controlled-Managed Documents:

1) Records generators will document reading of the PNNL-15848 (latest revision) Sampling and Analysis Plan, the Fluor Geologic Logging procedure, and appropriate ASTM procedures. Subsequent reading of document revisions will be documented.

2) Records generators will complete field forms. After forms are completed, the forms will be signed and dated. The signature signifies completeness and self review. Record generators will place forms in the "working, in-progress record" file. Photocopies of working, in-progress records are equivalent to an original; the original and copies will not be labeled.

3) The Quality Control Inspector will be independent from generation of records. The QC Inspector will review the records for completeness, legibility, and consistency. When 
deemed adequate, the QC Inspector will initial and date the record in lower left hand corner. This signifies completion by Freestone.

4) The Quality Control Inspector or designee will copy the record to one or more duplicate record locations. Designated duplicate records will be controlled in locked cabinets, briefcases, vehicles, or other protective environments.

5) Modifications

A. Changes will utilize a single strikeout of original material, addition/revision (if any), initial, and date.

B. Modifications by Record Generators of working, in-process forms will involve 1.) The change, 2.) Initial, 3.) Date

C. Modifications by Quality Control Inspector of completed records will involve 1.) The change, 2.) Initial, 3.) Date, 4.) A new QC initial and date in the lower left corner, 5.) Copy and distribution to all duplicate record files, 6.) The QC Inspector can request that logs be redone to ensure legibility.

6) Records Transfers

The QC Inspector will ensure transfer of required forms to client recipients. Informal, remaining copies and duplicate copies may then be destroyed or temporarily retained. All training records may be destroyed after completion of the project.

\section{Sample Process:}

1) Geologist/ Record Generator will identify samples on client-supplied containers, as required by client requirement documents. Special care will be exercised to ensure accuracy and marking of depths. Sample records shall correspond to paper forms for identifiers and depths.

2) Geologist/Record Generator will ensure that samples are stored and preserved from environmental damage, loss, or theft.

3) Quality Control Inspector will ensure consistency between markings on sample containers and paper records.

4) Quality Control Inspector will transfer sample containers and paper records to client organization in a timely fashion.

5) Quality Control Inspector will ensure record modifications and corrections as required by the client organization. The Quality Control Inspector will ensure distribution of corrected paper records to appropriate recipients.

\section{Informal Materials:}

Informal Materials are unofficial copies of working, in-process records; copies of completed records; supporting materials, such as articles, diagrams, scratch sheets, etc. Informal materials may be discarded, overwritten, or mutilated. Informal materials are uncontrolled with respect to storage and disposal. Informal materials need not be labeled as “copies.” Informal materials may not be distributed to individuals who are not Freestone Employees. 
WMP-32076 Rev. 0

Roles:

Geologist/ Record Generators:

Scot Adams, Ben Garcia, Steve Ahlquist, Colleen Rust, Jeff Fetters, Erika Rincon

Quality Control Inspector:

Greg Kasza, or Steve Airhart as Alternate 
WMP-32076 Rev. 0

This page intentionally left blank 
WMP-32076 Rev. 0

APPENDIX E

PHOTOGRAPHIC LOG OF BOREHOLE CUTTINGS

E - i 
WMP-32076 Rev. 0

This page intentionally left blank

E - ii 
WMP-32076 Rev. 0

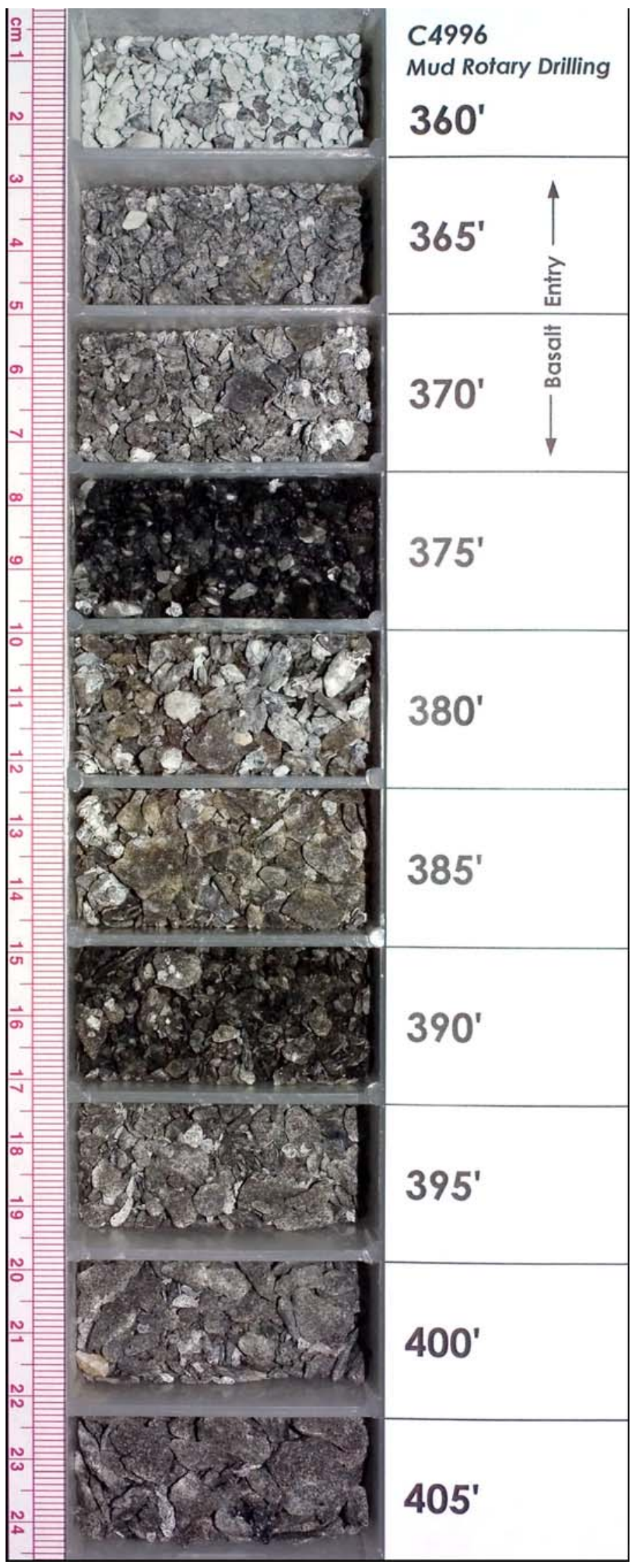

E - 1 
WMP-32076 Rev. 0

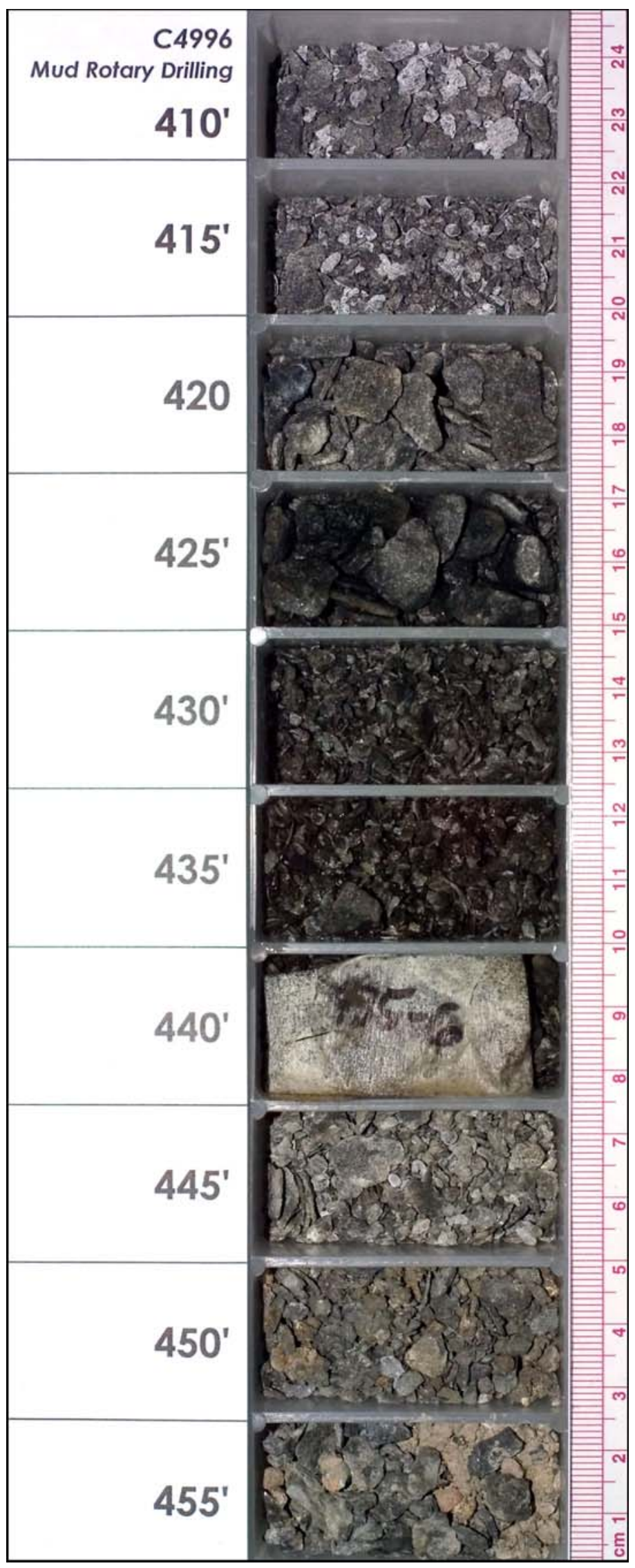

E - 2 
WMP-32076 Rev. 0

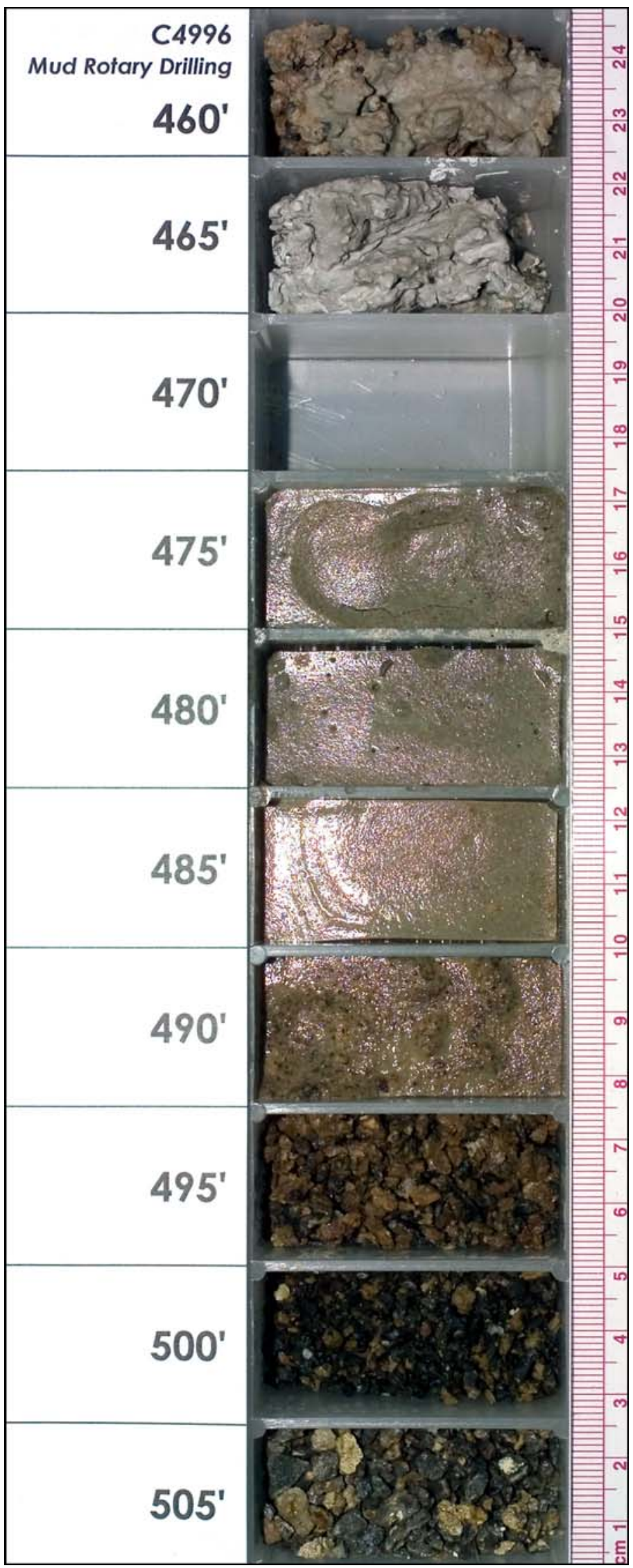

E - 3 
WMP-32076 Rev. 0

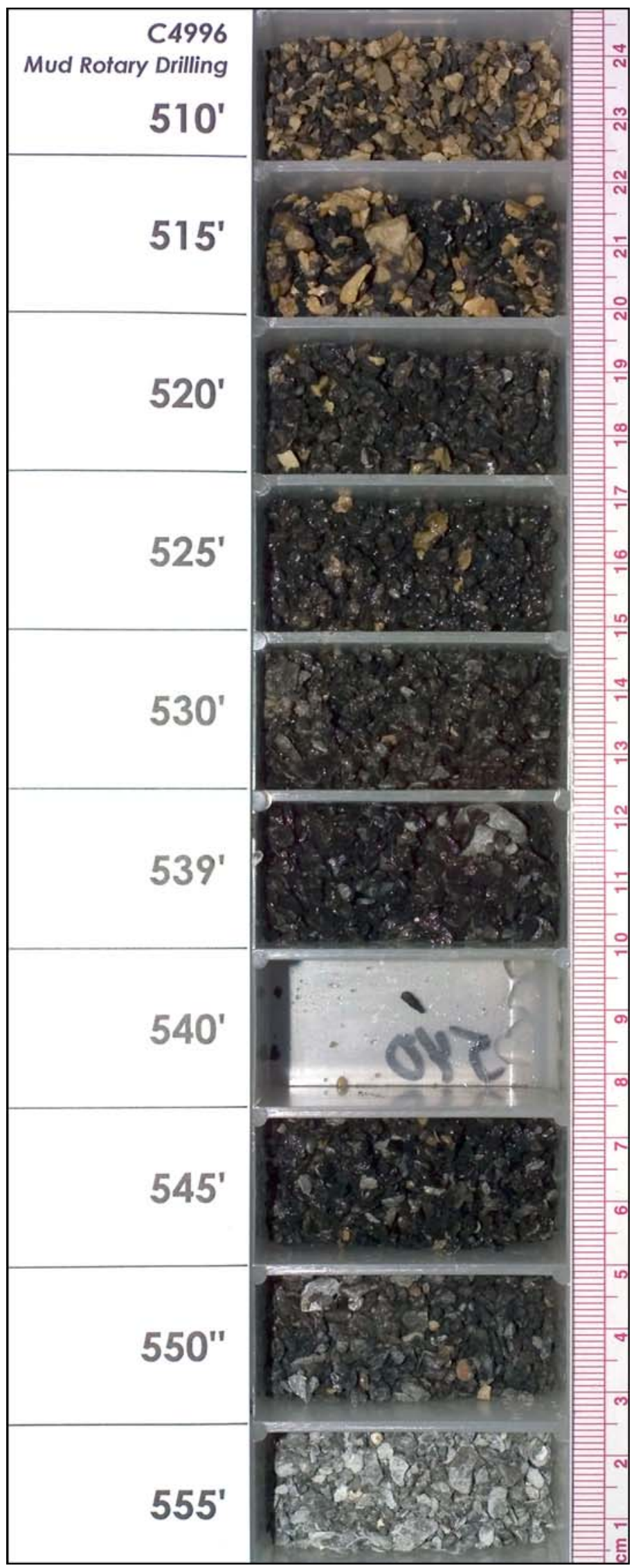

E - 4 
WMP-32076 Rev. 0

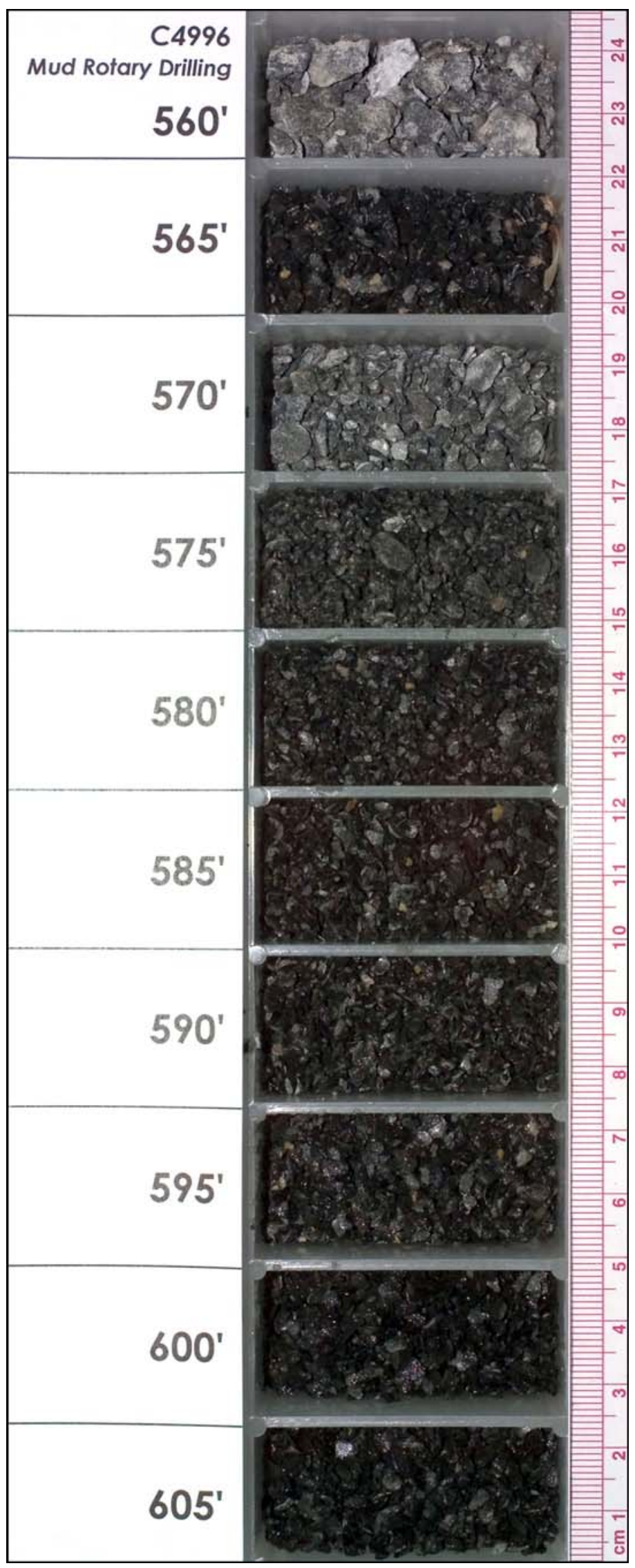

E - 5 
WMP-32076 Rev. 0

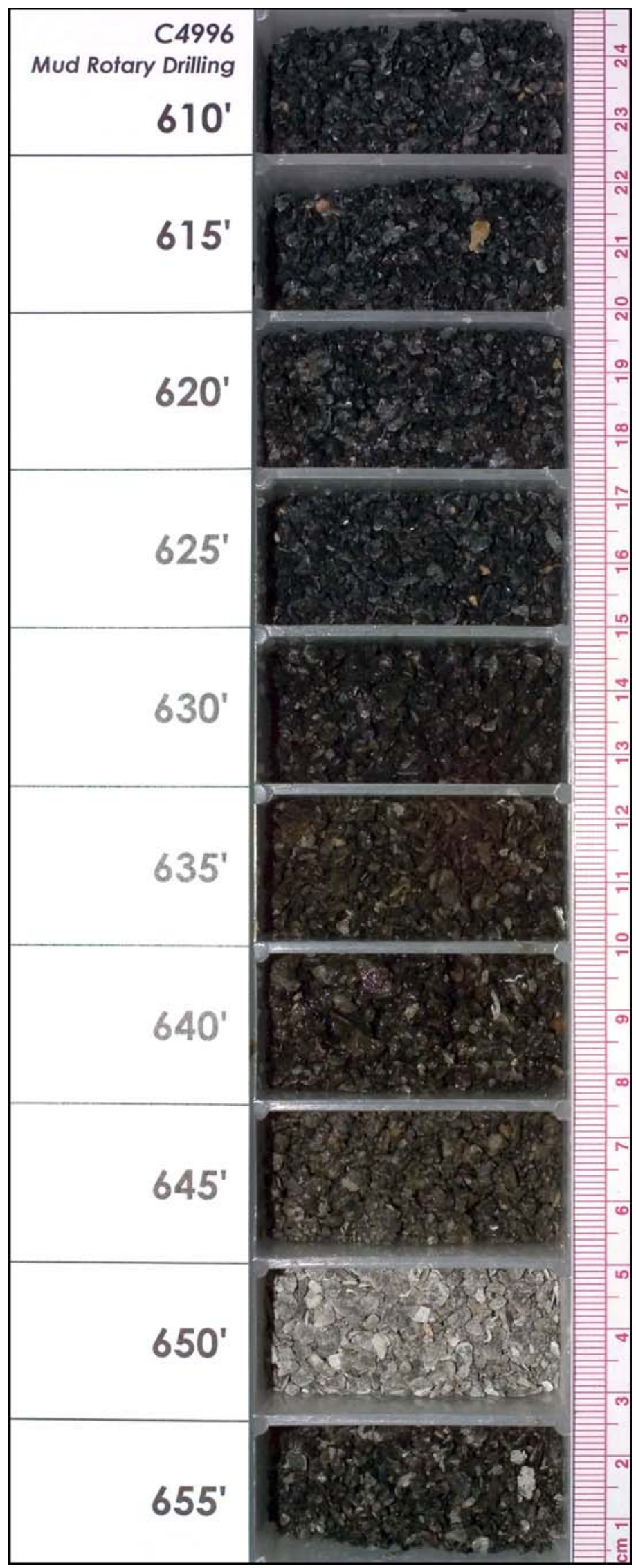

E - 6 
WMP-32076 Rev. 0

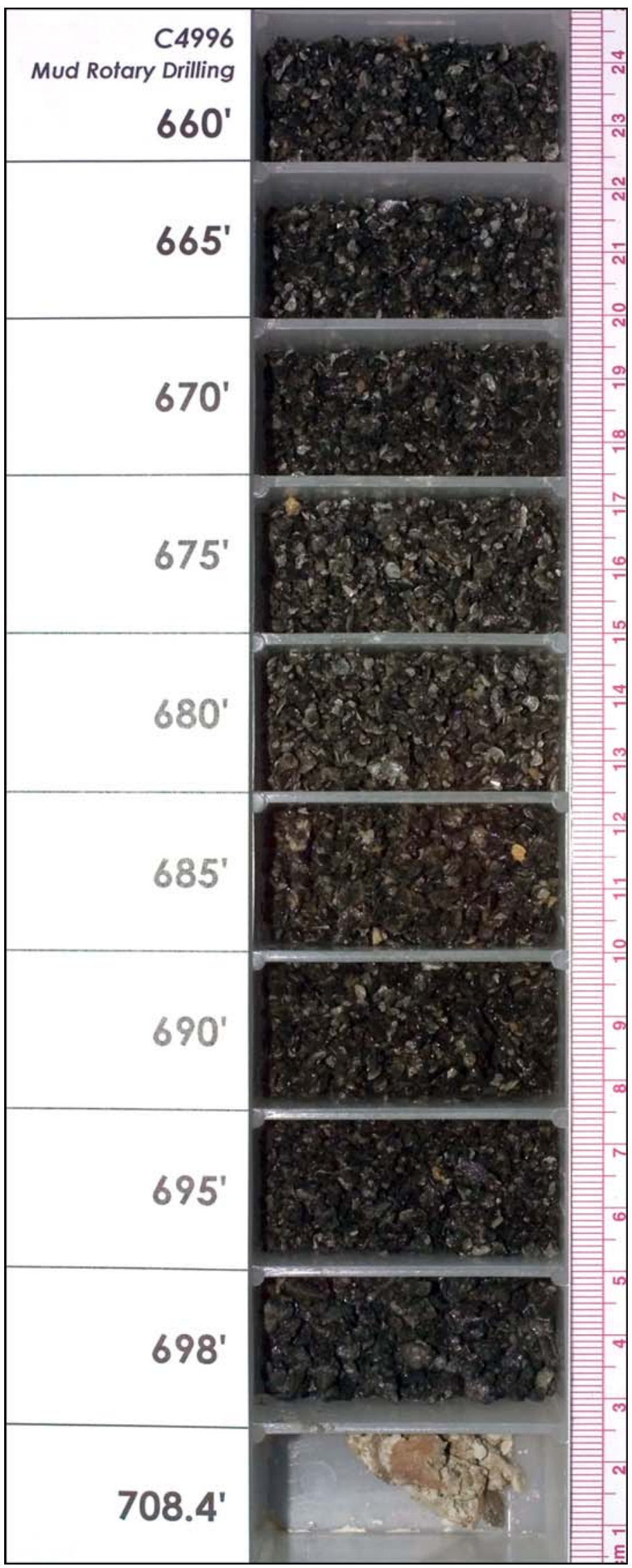

E - 7 
WMP-32076 Rev. 0

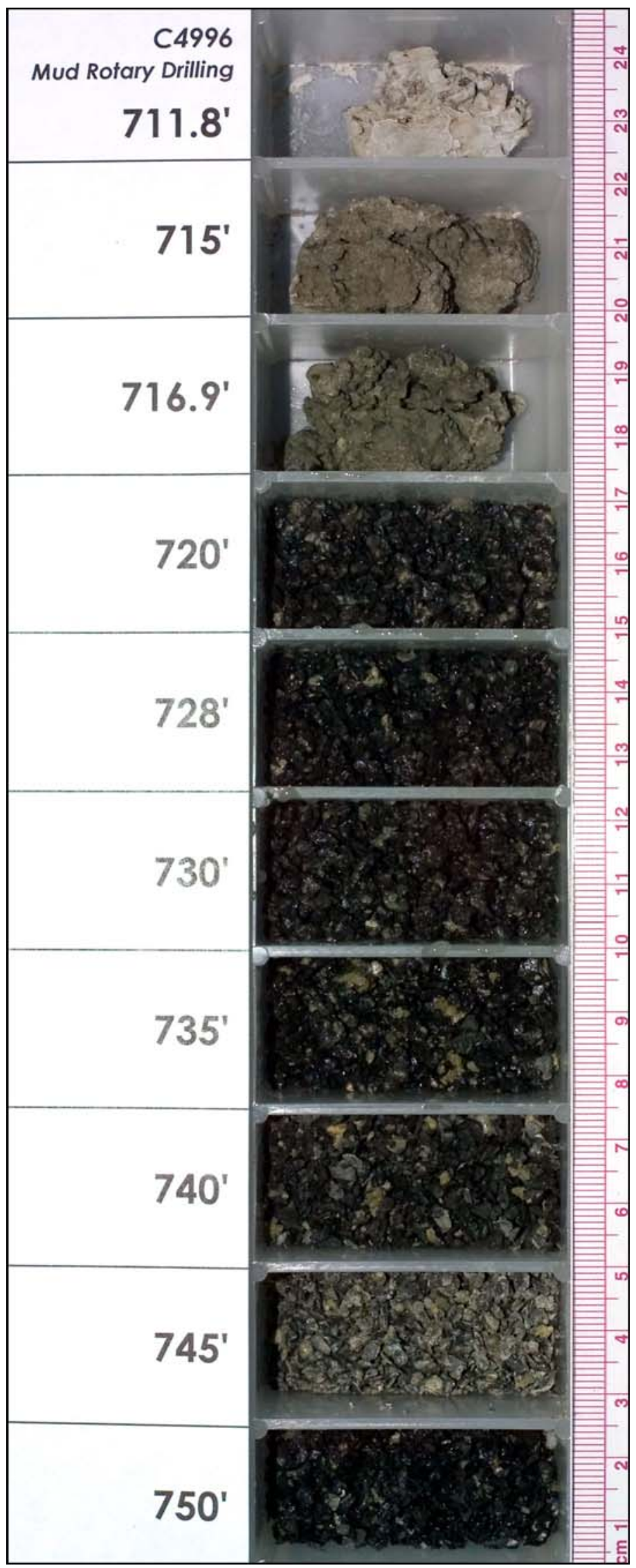

E - 8 
WMP-32076 Rev. 0

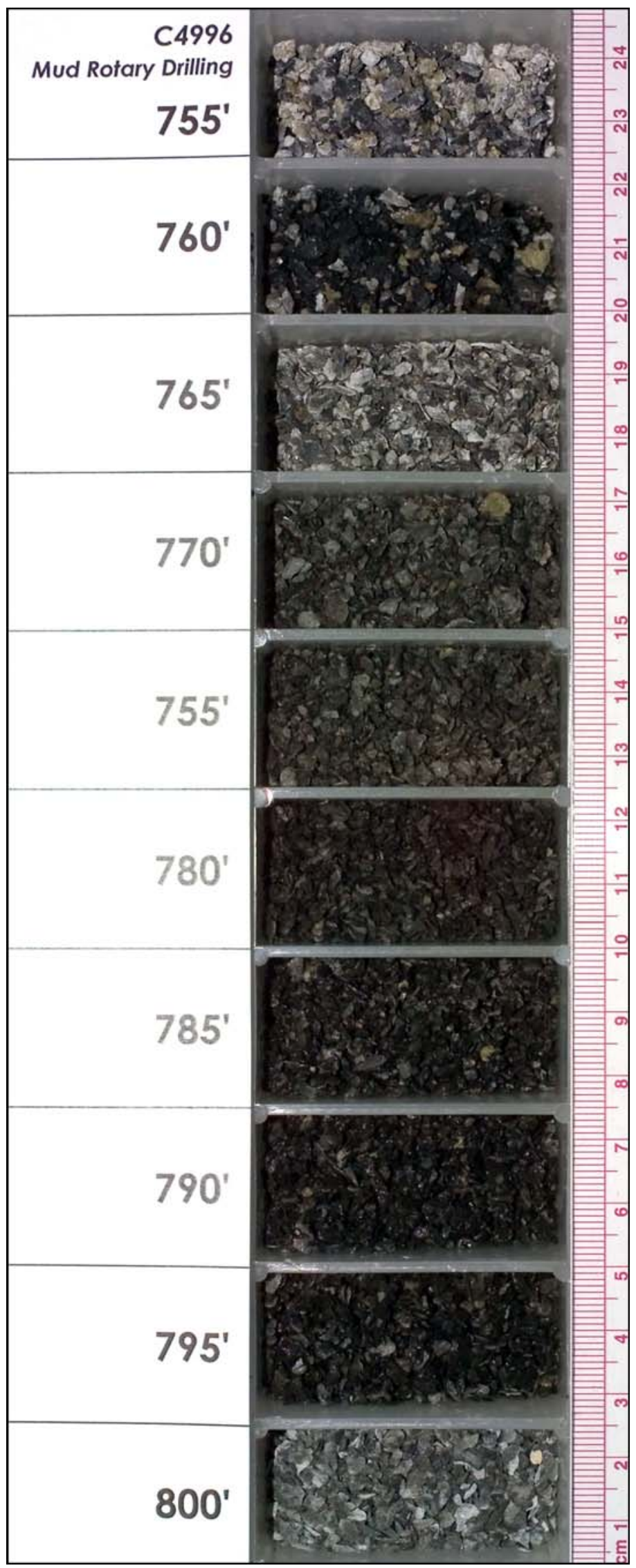

E - 9 
WMP-32076 Rev. 0

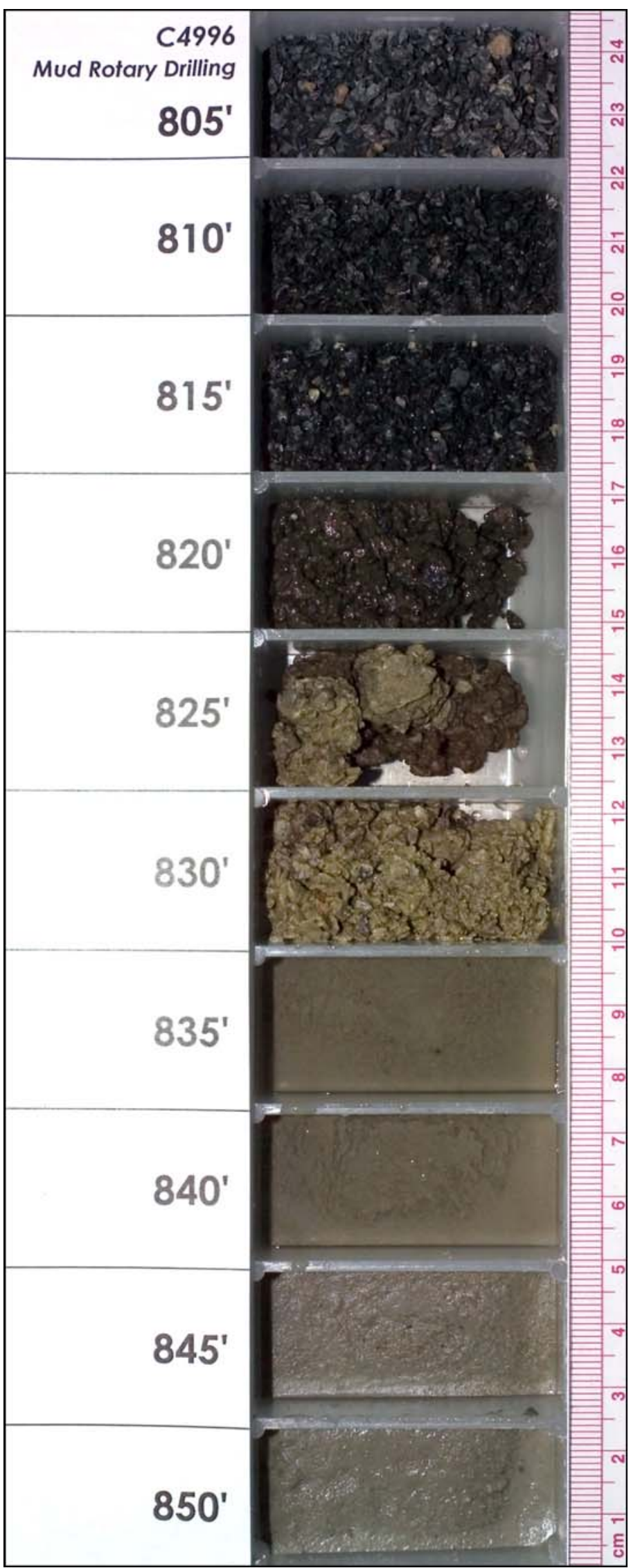

E - 10 
WMP-32076 Rev. 0

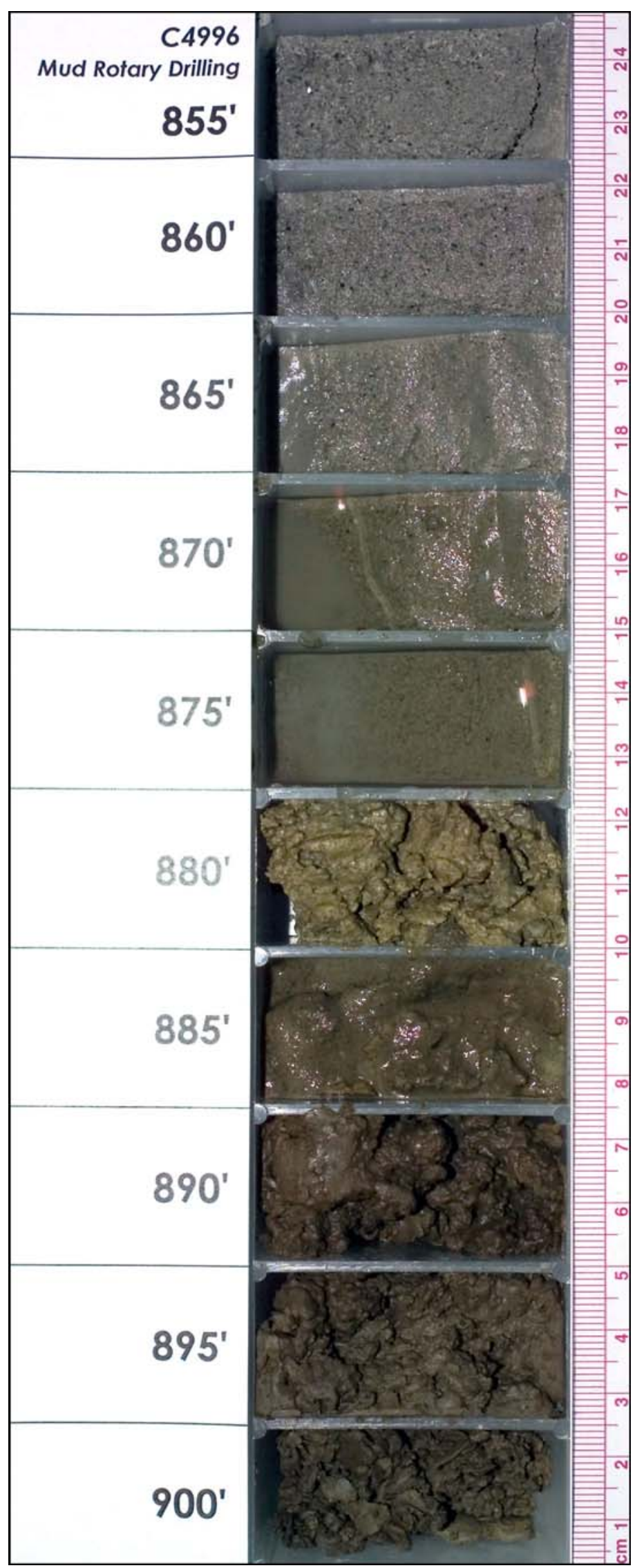

E - 11 
WMP-32076 Rev. 0

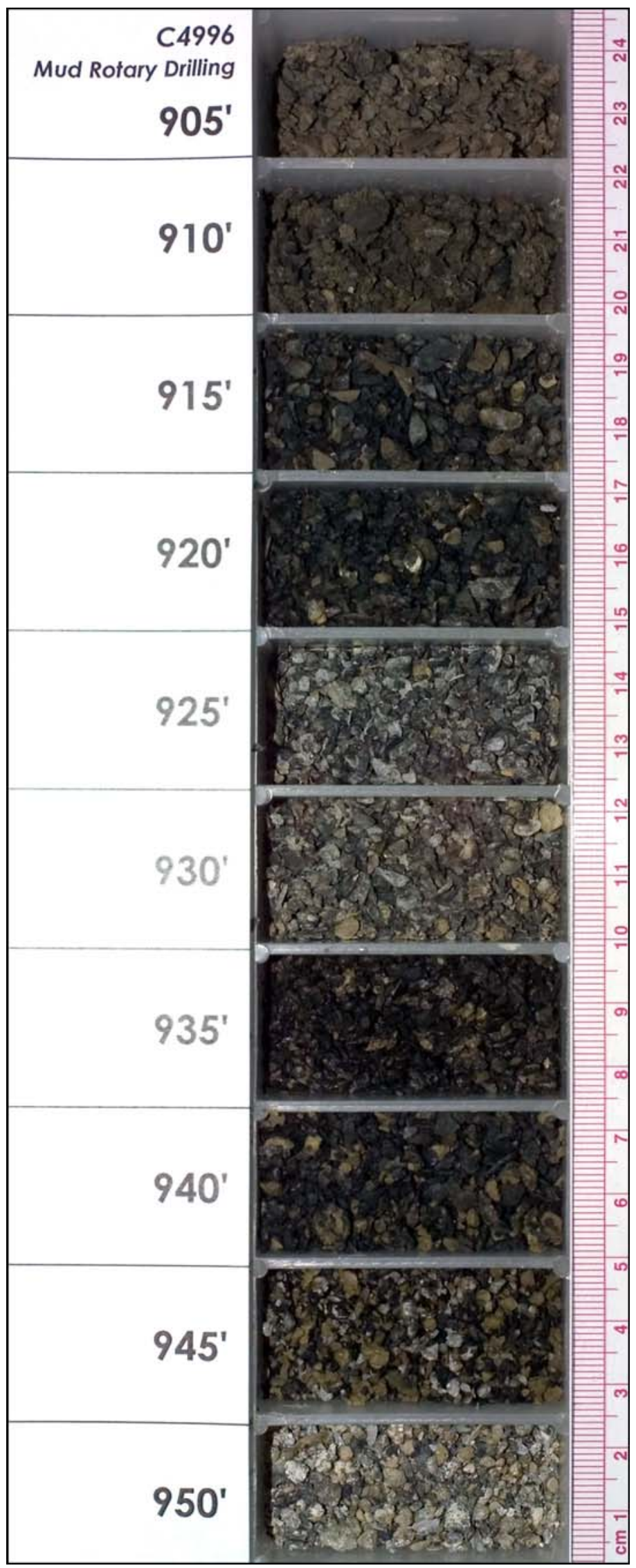

E - 12 
WMP-32076 Rev. 0

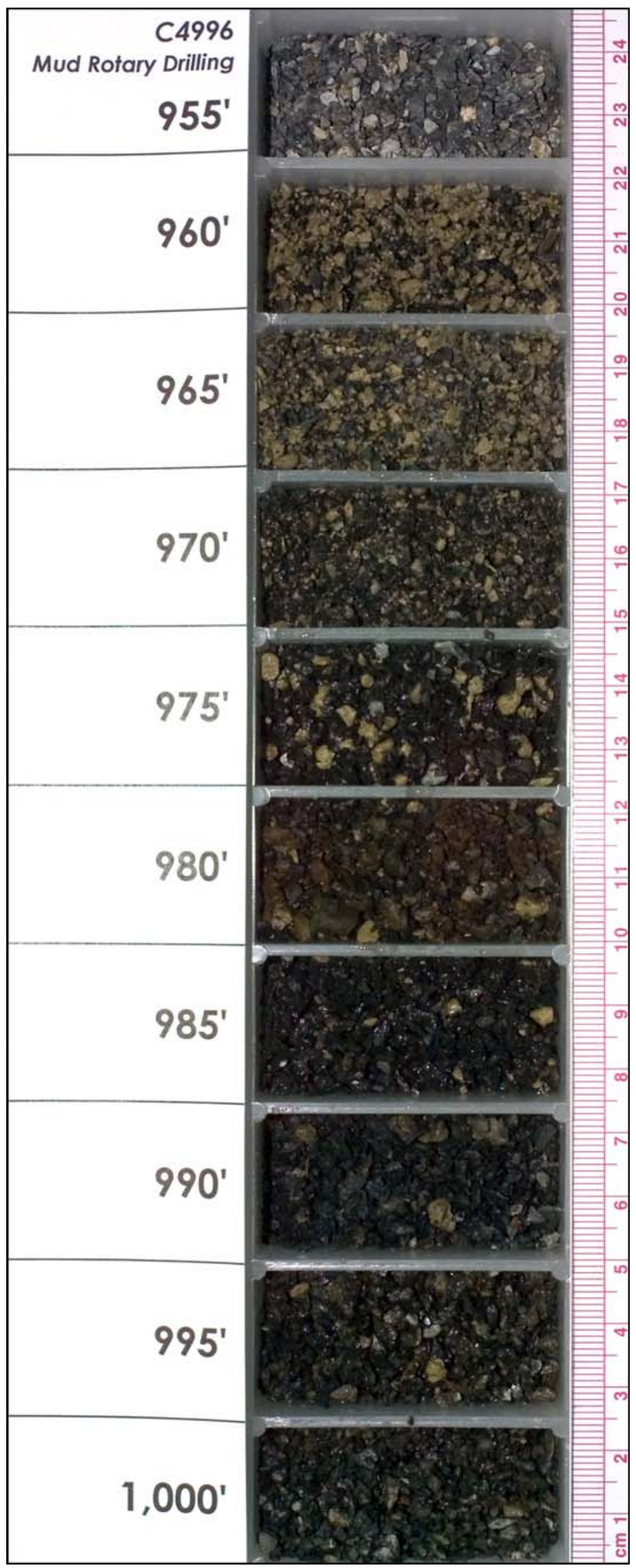

E - 13 
WMP-32076 Rev. 0

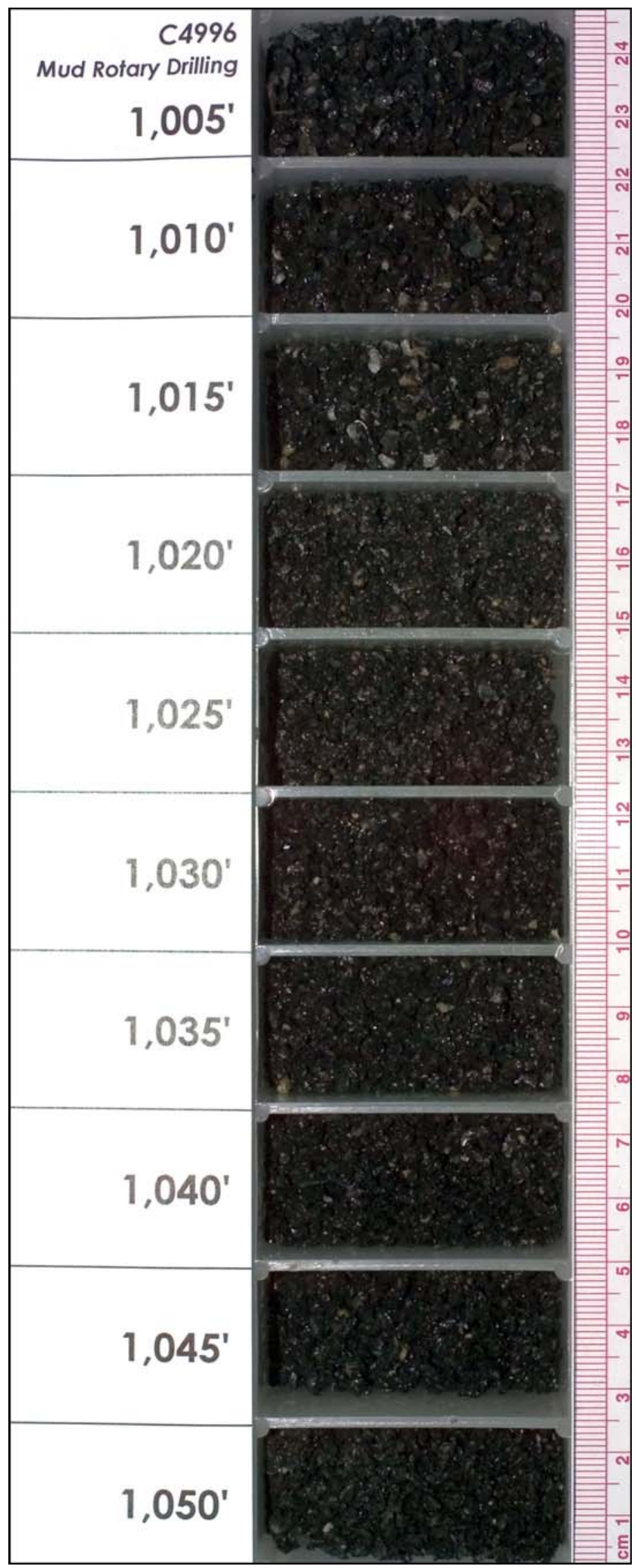

E - 14 
WMP-32076 Rev. 0

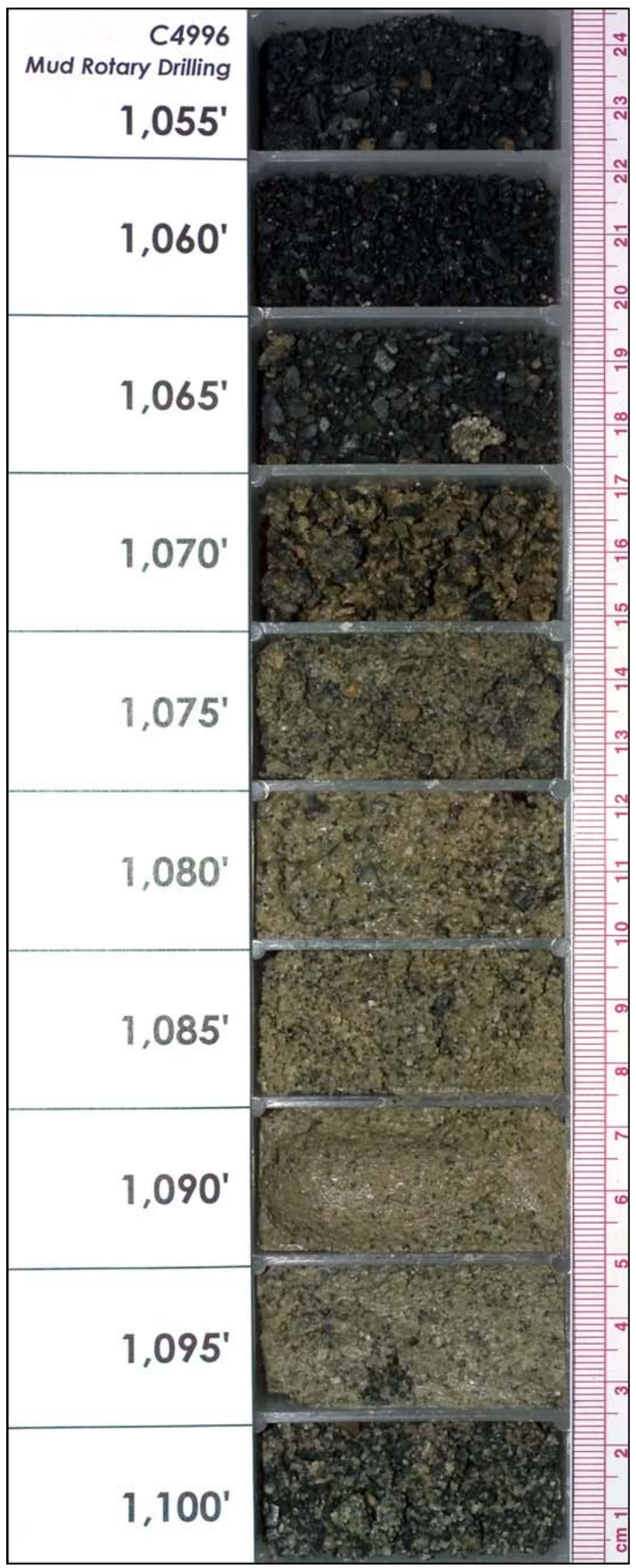

E - 15 
WMP-32076 Rev. 0

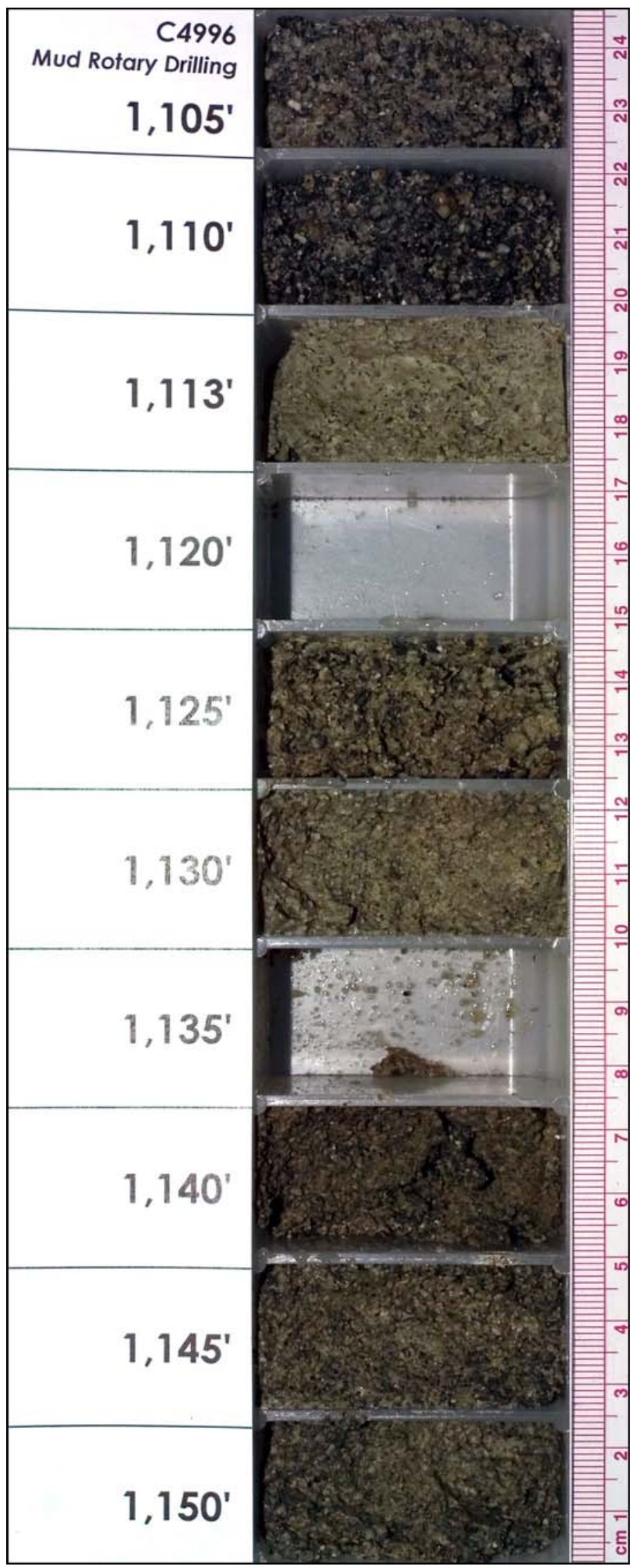

E - 16 
WMP-32076 Rev. 0

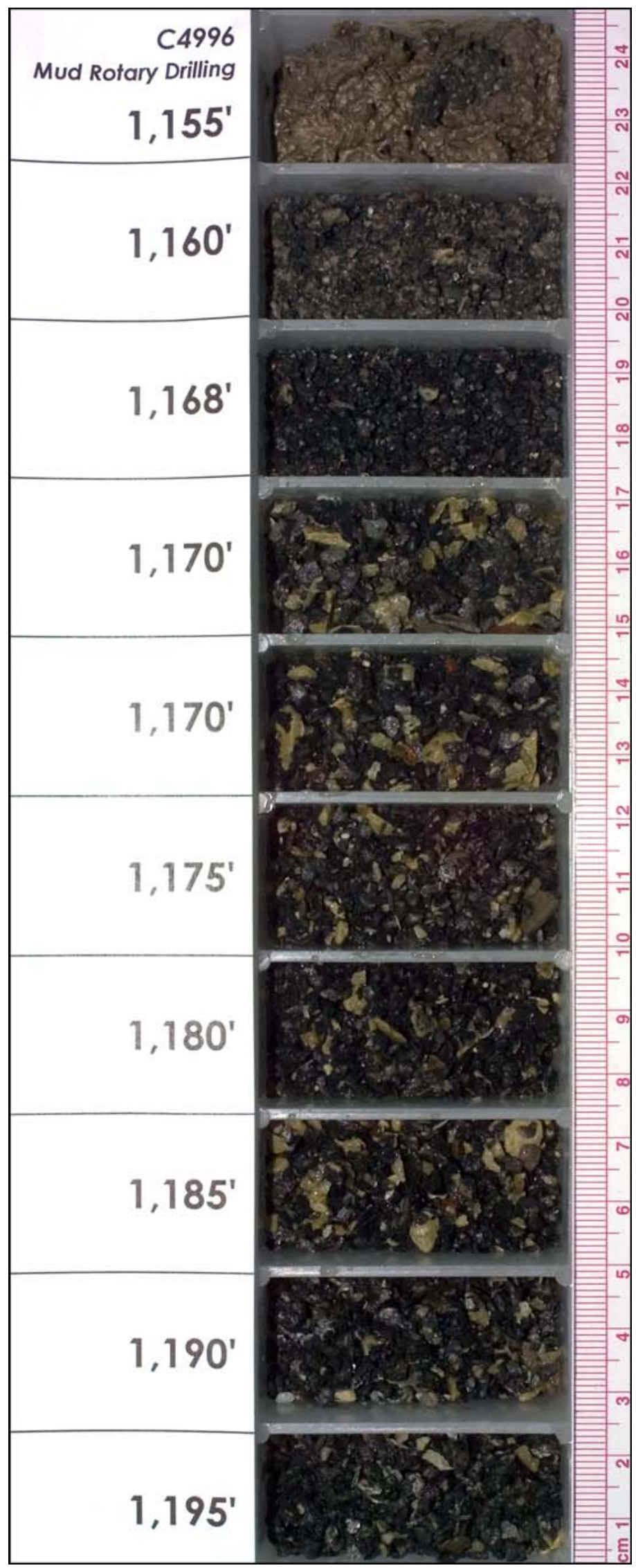

E - 17 
WMP-32076 Rev. 0

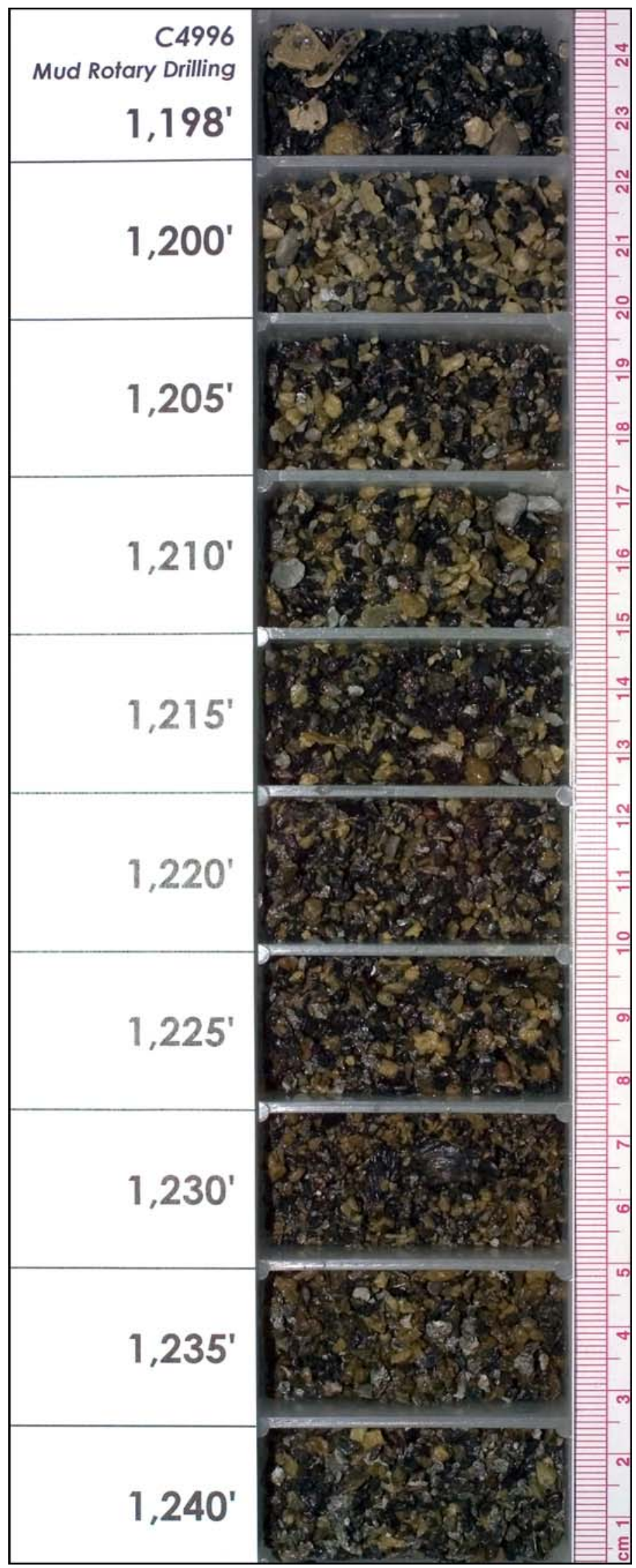

E - 18 
WMP-32076 Rev. 0

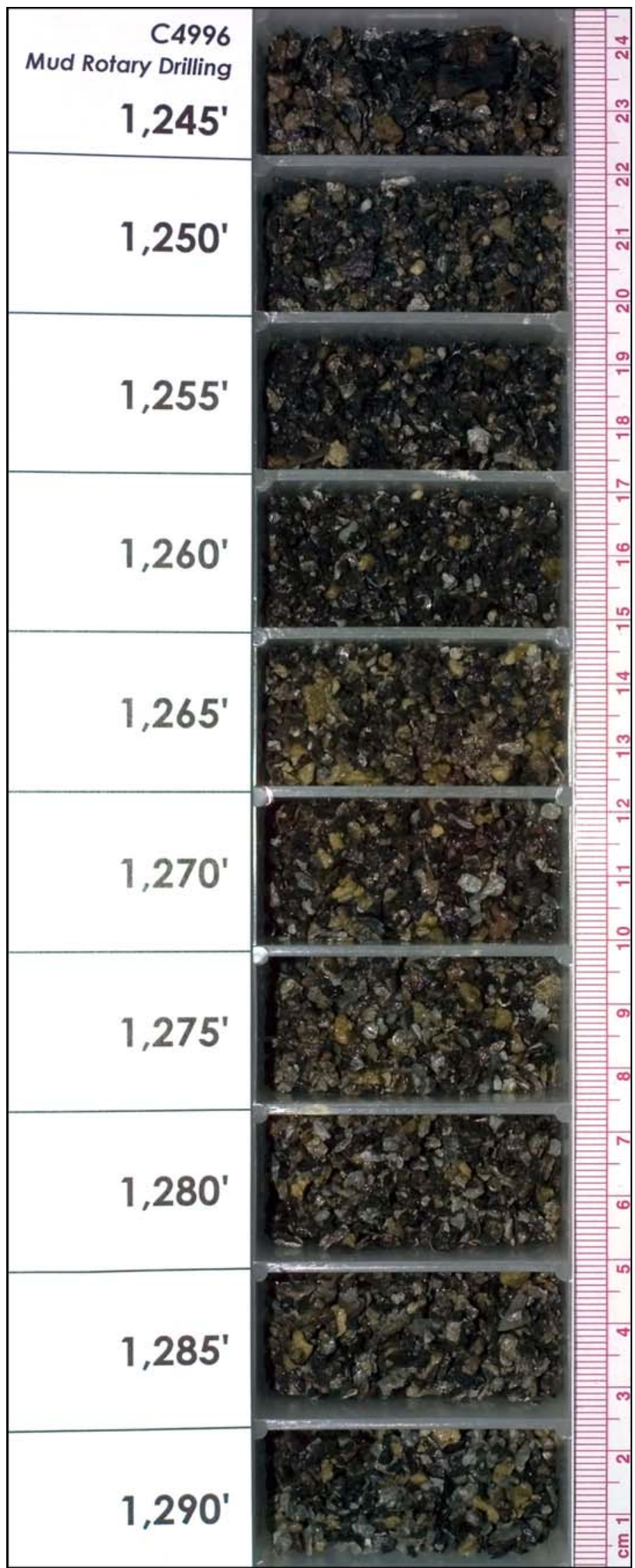

E - 19 
WMP-32076 Rev. 0

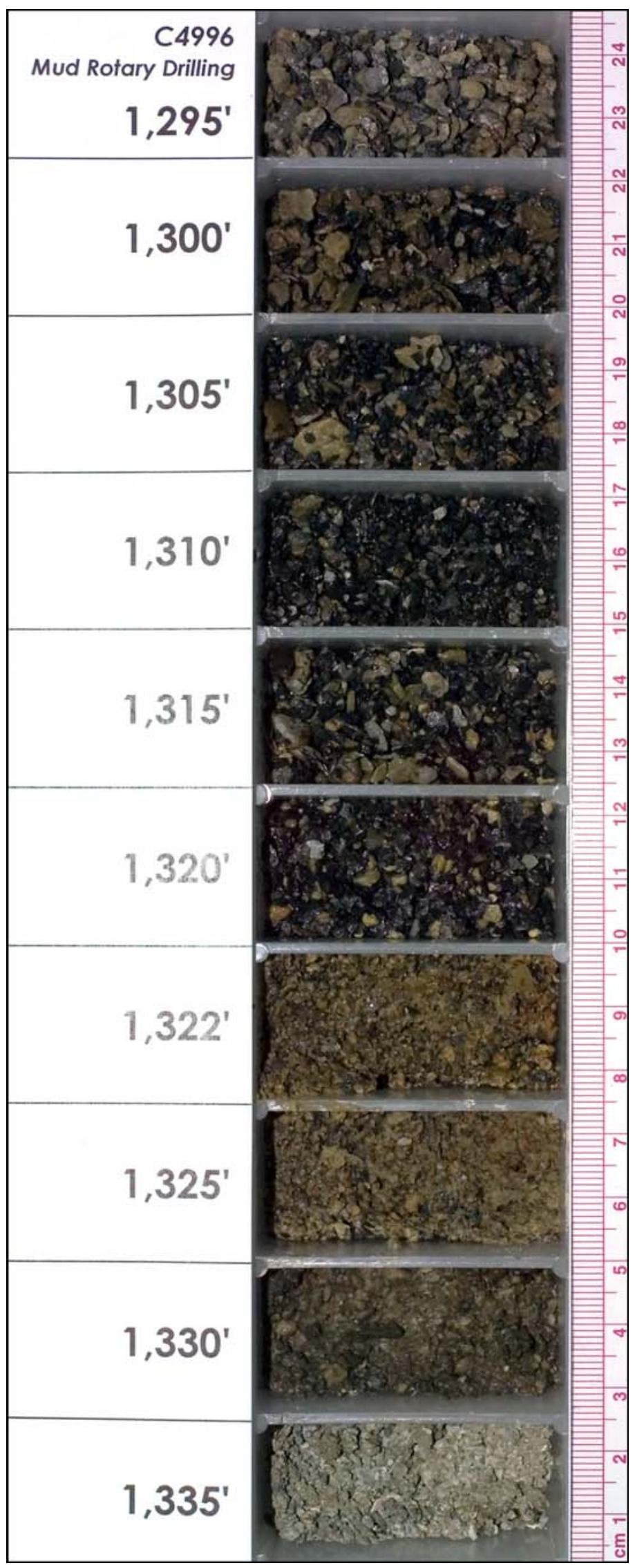

E - 20 
WMP-32076 Rev. 0

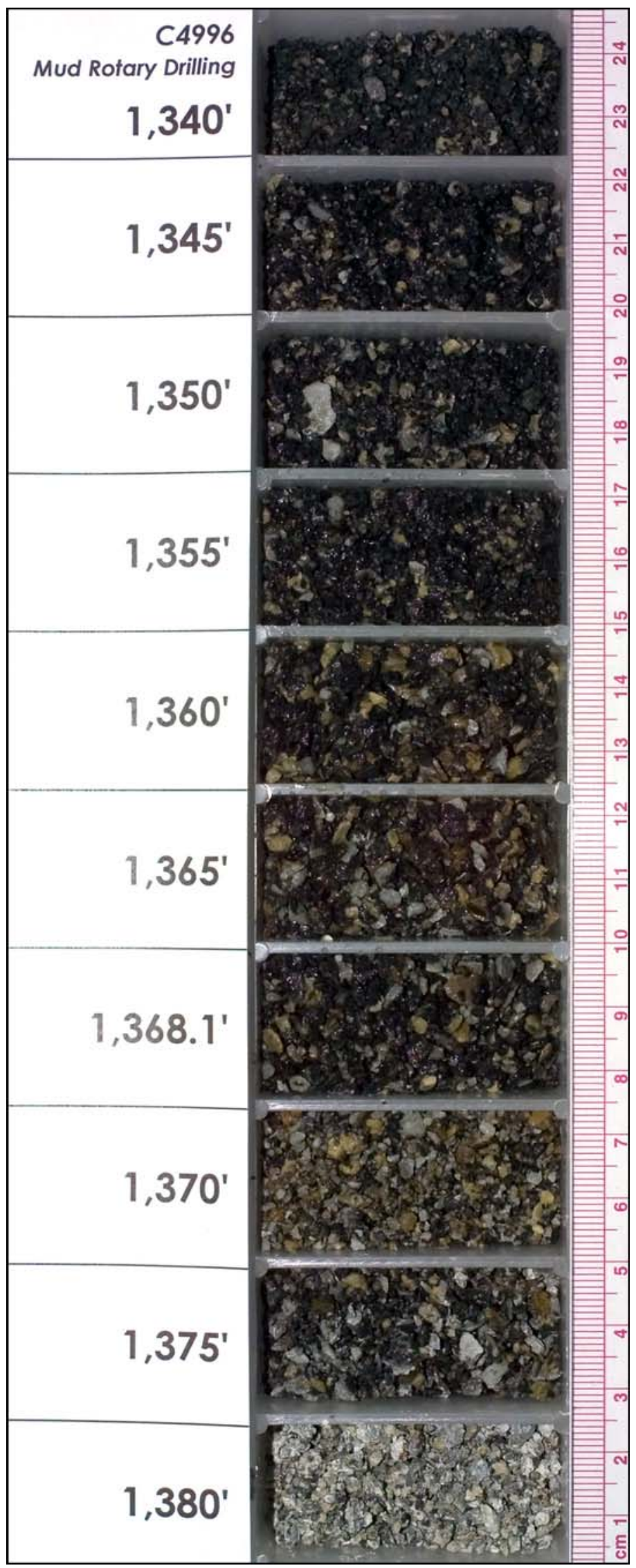

E - 21 
WMP-32076 Rev. 0

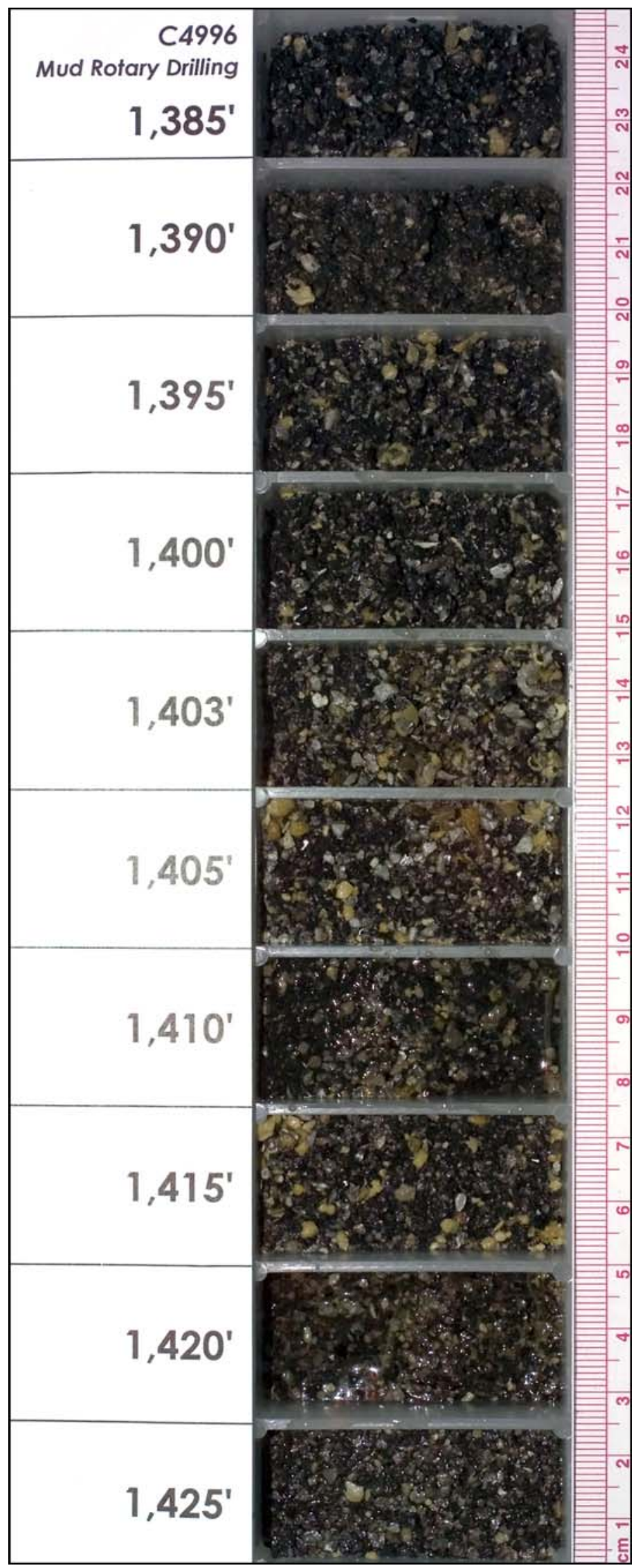

E - 22 
WMP-32076 Rev. 0

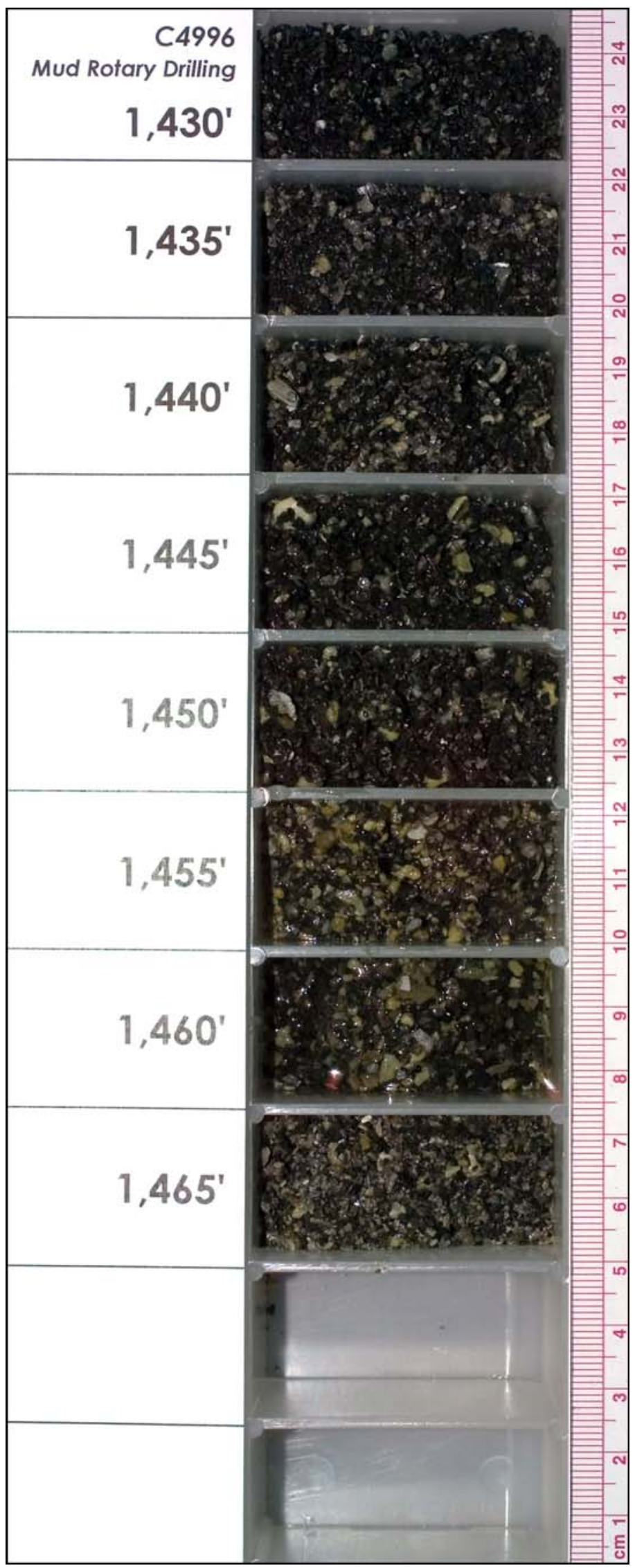

E - 23 
WMP-32076 Rev. 0

This page intentionally left blank

E - 24 
WMP-32076 Rev. 0

\section{DISTRIBUTION}

\section{$\underline{\text { Onsite }}$}

$1 \quad$ U.S. Department of Energy

$\underline{\text { Richland Operations Office }}$

DOE Public Reading Room

H2-53

6 Fluor Hanford, Inc.

L. J. Farrell

E6-35

L. C. Swanson

E6-35

L. D. Walker

E6-35

C. S. Wright

E6-35

$1 \quad$ Lockheed Martin Services, Inc.

Document Processing Center (1)

H6-08

$6 \quad$ Pacific Northwest National Laboratory

Hanford Technical Library

P8-55

D. B. Barnett

K6-75

T. M.Brouns

K6-69

S. P. Reidel

(3)

K6-75

6 Freestone Environmental Services, Inc.

Project Library

B2-63

S. C. Adams

B2-63

S. T. Ahlquist

B2-63

B. J. Garcia

B2-63

C. F. Rust

B2-63

J. R. Fetters

B2-63 
WMP-32076 Rev. 0

This page intentionally left blank

Distr - ii 